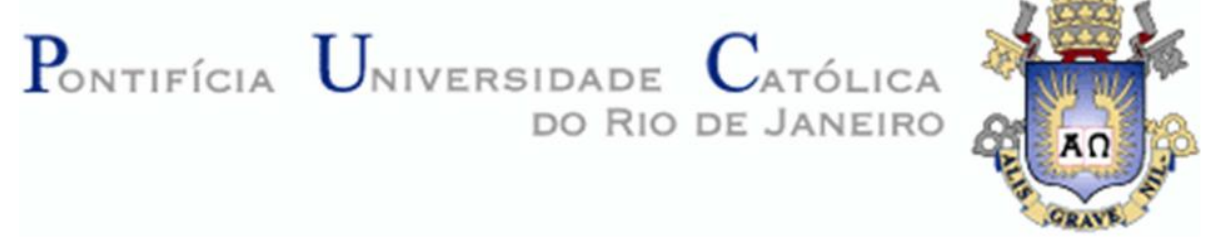

Camila Moraes de Oliveira

\title{
A gênese da Pastoral Afro-brasileira (PAB) e sua articulação contra o racismo
}

\section{Dissertação de Mestrado}

Projeto de Pesquisa apresentado ao Programa de Pós-Graduação Mestrado Acadêmico em Serviço Social da PUC-Rio, como requisito parcial para a obtenção do grau Mestre em Serviço Social.

Orientadora: Profa. Andréia Clapp Salvador 


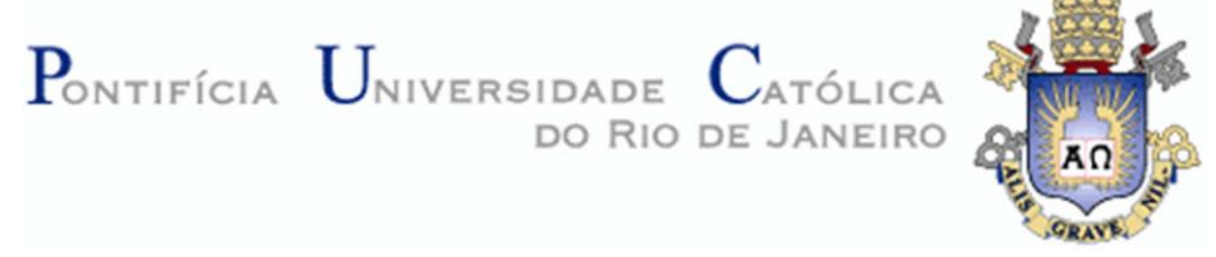

Camila Moraes de Oliveira

\section{A gênese da Pastoral Afro-brasileira (PAB) e sua articulação contra o racismo}

Dissertação de Mestrado

Dissertação apresentada como requisito parcial para a obtenção do grau de Mestre pelo Programa de Pós-Graduação em Serviço Social do Departamento de Serviço Social do Centro de Ciências Sociais da PUC-Rio. Aprovada pela Comissão Examinadora abaixo assinada.

Profa. Profa. Andréia Clapp Salvador

Orientadora

Departamento de Serviço Social - PUC-Rio

Profa. Ana Paula Procópio

Departamento de Serviço Social - UERJ

Prof. Celso Pinto Carias Departamento de Teologia - PUC-Rio

Profa. Rafael Soares Gonçalves Departamento de Serviço Social - PUC-Rio

Prof. Augusto Cesar Pinheiro da Silva Vice-Decano de Pós-Graduação do CCS- PUC-Rio

Rio de Janeiro, 31 março de 2018. 
Todos os direitos reservados. É proibida a reprodução total ou parcial do trabalho sem autorização da universidade, da autora e do orientador.

\section{Camila Moraes de Oliveira}

Graduada em Serviço Social na Universidade Federal do Rio de Janeiro (UFRJ) em 2014. Atuou como coordenadora durante três anos da Pastoral Afrobrasileira, que visa o diálogo cultural, ecumênico com valores afro-brasileiros. Membro do grupo de estudos e pesquisas em Trabalho, Políticas Públicas e Serviço Social (TRAPPUS), do Departamento de Serviço Social da Pontifícia Universidade Católica do Rio de Janeiro (PUC-Rio).

Ficha Catalográfica

Oliveira, Camila Moraes de

A gênese da Pastoral Afro-Brasileira (PAB) e sua articulação contra o racismo / Camila Moraes de Oliveira ; orientadora: Andréia Clapp Salvador. - 2018.

115 f. ; $30 \mathrm{~cm}$

Dissertação (mestrado)-Pontifícia Universidade Católica do Rio de Janeiro, Departamento de Serviço Social, 2018.

Inclui bibliografia.

1. Serviço social - Teses. 2. Pastoral Afro-brasileira. 3. Racismo. 4. Igualdade racial. I. Salvador, Andréia Clapp. II. Pontifícia Universidade Católica do Rio de Janeiro. Departamento de Serviço Social. III. Título. 
Sônia Regina, minha amada mãe, por todo o amor e confiança. A minha avó Terezinha, por me inspirar. E a todos os membros e simpatizantes da Pastoral Afrobrasileira.E aos meus amigos incentivadores. 


\section{Agradecimento}

Quero agradecer primeiro a minha força maior, que é Deus, por mais um sonho consumado. A minha mãe Sônia Regina, por tanta paciência e apoio nos momentos em que eu pensei em fraquejar. A minha avó Terezinha que me inspira diariamente, por ter a resistência não só na cor, mas, também em sua trajetória. Agradeço também as pessoas da minha família que mesmo involuntariamente emanaram energia positiva.

Agradeço também, a minha orientadora Andréia Clapp Salvador, por ter acreditado no meu pré-projeto e por todos os ensinamentos ao longo desses dois anos de mestrado. Muito obrigada por tudo!

Aos amigos que a vida me deu em específicos momentos desse plano terrestre, que considero irmãos, por ter em alguns momentos acreditado mais no meu potencial do que eu mesmo. O meu sincero agradecimento!

A minha terapia diária, Aline Lourenço, Lorena Anile e Priscila Ambrozio, o meu muito obrigado, pois, não imagino como seria esse momento de produção sem o apoio, carinho e companheirismo de vocês. E que possamos seguir, sem sermos "Obrigadas a nada".

Agradeço aos meus amigos e companheiros de luta da Pastoral Afrobrasileira da Arquidiocese do Rio de Janeiro, pelo incentivo e por todo o apoio nessa pesquisa. Vocês foram fundamentais na conclusão dessa etapa na minha trajetória acadêmica. Aproveito também, para agradecer a todas as lideranças e participantes de cada PAB que eu visitei ao longo do mestrado, pelo acolhimento e pela troca.

Ao CNPq e à PUC-Rio, pelos auxílios concedidos, sem os quais este trabalho não poderia ter sido realizado e pela receptividade, meu muito obrigada. 


\section{Resumo}

Oliveira, Camila Moraes; Clapp, Andréia Salvador. A gênese da Pastoral Afro-brasileira (PAB) e a sua articulação contra o racismo. Rio de Janeiro, 2018, 115 p. Dissertação de Mestrado - Departamento de Serviço Social, Pontifícia Universidade Católica do Rio de Janeiro.

A referida dissertação tem por objetivo exibir os resultados da pesquisa de mestrado em que procurou ressaltar a gênese da Pastoral Afro-brasileira (PAB) e sua importância na articulação contra o racismo. O projeto está inserido na linha de pesquisa Trabalho, Políticas Sociais e Sujeitos Coletivos do programa de Pós-graduação do Departamento de Serviço Social da PUC Rio e o propósito central do presente estudo é analisar o surgimento e a criação da PAB, para que assim possa compreender seu papel em prol da igualdade racial. Tendo como objetivo geral, compreender a gênese da Pastoral Afro-brasileira e sua ação na questão racial, assim como, identificar como se constituem as ações norteadoras da PAB no campo racial, qual a representação que a identidade afro-brasileira tem para seus membros e principais protagonistas da PAB. A pesquisa foi de cunho qualitativo, com a perspectiva de responder questões que não poderiam ser quantificadas, sendo utilizada para a mesma, uma entrevista semiestruturada. O primeiro capítulo da pesquisa consiste em relatar a história da constituição da Pastoral Afro-brasileira, ressaltando toda a trajetória de formação da Pastoral, enfatizando a Campanha da Fraternidade de 1988, que é o marco histórico para o surgimento da PAB. E no capítulo seguinte, a pesquisa sintetiza a gênese da Pastoral Afro-brasileira no olhar dos protagonistas leigos e religiosos envolvidos com as articulações da Pastoral. Concluo a pesquisa com as considerações da importância que a articulação e reflexão social que a PAB dispõe, enriquecem a luta em prol da igualdade racial.

\section{Palavras-chave}

Pastoral Afro-brasileira; Racismo; igualdade racial. 


\section{Abstract}

Oliveira, Camila Moraes; Clapp, Andréia Salvador (Advisor). The genesis of the Afro-Brazilian Pastoral (PAB) and its articulation against. Rio de Janeiro, 2018, 115 p. Dissertação de Mestrado - Departamento de Serviço Social, Pontifícia Universidade Católica do Rio de Janeiro.

The purpose of this dissertation is to show the results of the master's research in which it sought to highlight the genesis of the Afro-Brazilian Pastoral $(\mathrm{PAB})$ and its importance in articulating against racism. The project is part of the research line of Work, Social Policies and Collective Subjects of the Postgraduate Program of the Department of Social Work of PUC Rio and the main purpose of this study is to analyze the emergence and creation of the PAB, so that it can understand their role in favor of racial equality. Having as a general objective, to understand the genesis of the Afro-Brazilian Pastoral and its action on the racial issue, as well as to identify how the guiding actions of the PAB in the racial field are constituted, what is the representation that the Afro-Brazilian identity has for its members and main protagonists of the PAB. The research was qualitative, with the perspective of answering questions that could not be quantified, being used for the same, a semistructured interview. The first chapter of the research is to describe the history of the formation of the Afro-Brazilian Pastoral, emphasizing the whole formation process of the Pastoral, emphasizing the Brotherhood Campaign of 1988, which is the historical landmark for the emergence of PAB. And in the next chapter, the research synthesizes the genesis of the Afro-Brazilian Pastoral in the perspective of the lay and religious protagonists involved with the articulations of the Pastoral. I conclude the research with the considerations of the importance that the articulation and social reflection that the PAB has, enrich the fight for racial equality.

\section{Keywords}

Afro-Brazilian Pastoral; Racism; racial equality. 


\section{Sumário}

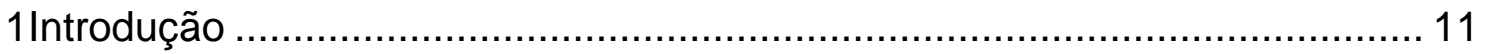

2 Consideração histórica da constituição da Pastoral Afro-brasileira ................ 16

2.1 Trajetória inicial da Pastoral Afro-brasileira ............................................ 17

2.2 Um novo olhar da Igreja para a questão social ........................................ 30

2.3 Ouvi o Clamor Deste Povo, Campanha da Fraternidade que deu voz

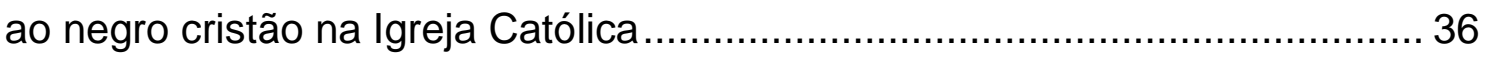

2.5 O pilar de atuação da Pastoral Afro-brasileira ......................................... 47

3 A gênese da Pastoral Afro-brasileira no olhar dos seus protagonistas ......... 60

3.1 As perspectivas sobre a Pastoral Afro-brasileira na visão dos líderes

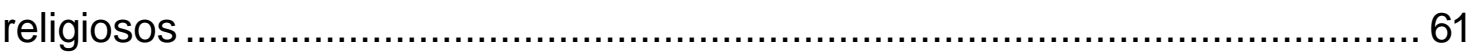

3.1.1 O surgimento da Pastoral Afro-brasileira através do olhar dos líderes

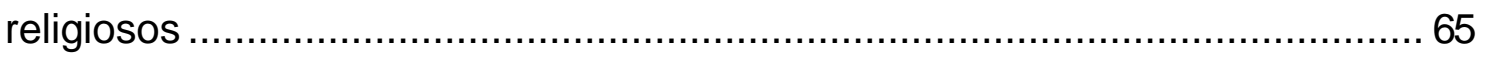

3.1.2 A importância das atividades da Pastoral Afro-brasileira na

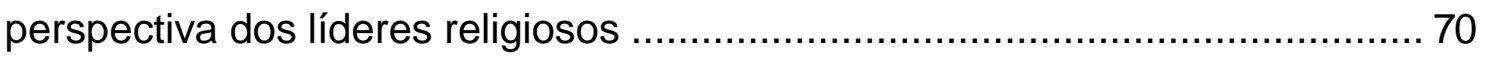

3.2 A análise dos membros leigos sobre a importância da Pastoral Afrobrasileira.

3.2.1 O surgimento da Pastoral Afro-brasileira através do olhar dos leigos ..... 83

3.2.2 A análise so as atividades concretas desenvolvidas pela Pastoral Afro-brasileira.

3.2.3 A questão racial e a reflexão social da Pastoral Afro-brasileira através dos protagonistas da Pastoral Afro-brasileira .................................. 100

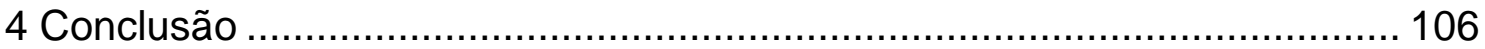

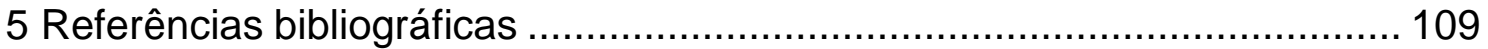

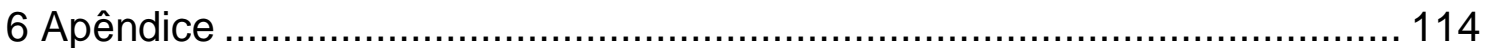

6.1 Questionário para os membros da Pastoral Afro-brasileira ...................... 114

6.2 Questionário para os líderes religiosos participantes da Pastoral Afrobrasileira. 


\section{Lista de siglas}

APN - Agente de Pastoral Negro

CEB - Comunidade Eclesial de Base

CELAM - Conselho Episcopal Latino - Americano

CF - Campanha da Fraternidade

CNBB - Conferência Nacional dos Bispos Brasileiros

CONENC - Congresso Nacional das Entidades Negras Católicas

EPA - Encontro de Pastoral Afro-americana e Caribenha

GRUCON - Grupo de União e Consciência Negra

PAB - Pastoral Afro-brasileira

PMM - Pastoral da Mulher Marginalizada

PO - Pastoral Operária

MNU - Movimento Negro Unificado

SPM - Serviço Pastoral dos Migrantes

SEPAC - Secretaria da Pastoral Afro-latino-americana e Caribenha 
"Ancestral, me fale de respeito. Me ensina a lição dos mestres E das crianças do teu céu. Oxalá. Me mostra o lugar seguro Faz de nós iguais na fé. Proteção para o povo / Protege o meu povo" 


\section{Introdução}

A sociedade vive o mito da democracia racial, conforme analisado por Octavio lanni (2004), que é proveniente da ideologia do branqueamento, que determina através da cor da pele do indivíduo quem é digno de oportunidades. Capaz de instaurar socialmente a intolerância étnica, o preconceito racial, a discriminação racial e principalmente o racismo.

Tendo em vista que essa é uma dinâmica entranhada na sociedade desde o período em que negros eram escravizados, explorados e estigmatizados, torna-se fundamental que haja ações que dinamizem a igualdade racial. E essa ação é desenvolvida por Grupos organizados, Movimentos Sociais, Movimento Negro e Pastoral Social da Igreja Católica, como a Pastoral Afro-brasileira, que é o objeto central da pesquisa.

A Igreja Católica, após o surgimento da Teologia da Libertação, voltou minuciosamente sua atenção para a questão social, que envolve diversas expressões, centralizando seu olhar para os excluídos. Através dessa teologia, a Igreja priorizou seu olhar para os que eram mais vulneráveis socialmente, seja por sua classe social ou pela cor da sua pele e passou a intervir de maneira mais efusiva no âmbito social, levando a temática para as Conferências que sucederam essa nova visão da lgreja.

Porém antes da Teologia da Libertação, que é o período que a Igreja Católica passa por uma guinada de posicionamento e inicia um processo histórico que evidencia sua preocupação e atuação em prol da questão social. Incluindo em seus encontros e Conferências temáticas que aludem as angústias e anseios do homem contemporâneo, que sofre com as transformações sociais, conforme sinalizado no Concílio Vaticano II.

"(...) a grave ameaça de um mundo que se constrói sobre a injustiça, a cobiça, a luta pelo poder e a violência. Proclama, novamente, a primazia do homem, pelo seu valor e dignidade. Defende a organização a organização do mundo em função da felicidade do homem e condena, de modo radical, toda forma de discriminação e diminuição da pessoa (...)". (Texto base da Campanha da Fraternidade de 1988, p. 79)

Considera-se que a Teologia da Libertação e o Concílio Vaticano II, provocaram o surgimento da Conferência de Medellín (1968), que foram determinantes para que a Igreja Católica aprofundasse sua consciência para 
perceber que a sociedade sofre com a injustiça em sua estrutura e que seu posicionamento não poderia ser omisso novamente, como quando no período da escravidão. Com isso, já na Conferência de Puebla (1979), a condenação de todo tipo de discriminação, preconceito, marginalização e racismo no seio da Igreja Católica fica mais latente. Permitindo, que movimentações em prol da igualdade racial, tomasse espaço dentro da instituição.

Através desse posicionamento, surgiram Grupos de estudos sobre a temática racial dentro da Igreja, que não se importavam apenas com o racismo da instituição, mas se preocupavam em conscientizar a comunidade local, sobre a importância de evidenciar a cultura afro em todos os âmbitos sociais. Essa militância dos negros cristãos, fez com que surgissem o Grupo de Agentes de Pastoral Negros (APN), que articulou e reivindicou que a CNBB (Conferência Nacional dos Bispos do Brasil) dedicasse a Campanha da Fraternidade de 1988 aos negros, em virtude da comemoração aos 100 Anos da Abolição da Escravatura.

O objetivo foi alcançado pelos negros militantes inseridos na Igreja Católica e assim foi consumado a Campanha da Fraternidade (CF) de $1988 \mathrm{com}$ o tema "Fraternidade e o Negro", com o lema - "Ouvi o clamor deste povo". E após a CF de 88, como é conhecida entre os Católicos, foi criada a Pastoral Afro-brasileira, que exprimiu os anseios e demandas que assolam os negros até os tempos atuais, em virtude também dos resquícios deixados pelo período da escravidão e pelo racismo que é um elemento estrutural.

\begin{abstract}
A Pastoral Afro-brasileira procurou que os seus Agentes de Pastoral, num contexto teológico, onde se valoriza as experiências das comunidades e o compromisso com os mais pobres, e assim, desenvolvesse um processo de formação onde confronta a fé com as injustiças feitas aos pobres. Essa teologia é a partir de um novo lugar social e daí surgem alguns sinais que revelam uma espiritualidade. (Araújo, 2015, p. 01)
\end{abstract}

A pesquisa tem o propósito de analisar a gênese da Pastoral Afrobrasileira, ou seja, descrevendo o caminho percorrido para que os negros militantes cristãos se sentissem mais pertencentes da Igreja Católica, ressaltando através da PAB suas demandas, desenvolvendo diálogos entre grupos religiosos e a sociedade civil. Com o propósito de tornar visível a cultura e identidade afro. Porém, esse anseio exige que ocorra um diálogo interreligioso, proporcionando uma maior interação com as religiões de Matriz Africana. 
O interesse em deslindar sobre a Pastoral Afro-brasileira surgiu após o convite do Pároco Luiz Antônio (padre responsável pela comunidade paroquial) da Matriz Santa Rosa de Lima, localizada no bairro de Jardim América na Zona Norte da cidade do Rio de Janeiro. Após ter aceitado o convite, iniciei uma pesquisa para entender melhor como iniciou a Pastoral Afro-brasileira, assim como, entender como ocorria sua articulação e quais eram seus objetivos.

$\mathrm{E}$ através dessa pesquisa, constatei que haviam apenas documentos religiosos que ressaltavam o papel evangelizador da Pastoral Afro-brasileira e não centravam na sua reflexão social. Por conseguinte, me despertou o interesse em estudar a gênese e a articulação da Pastoral, com o intuito de salientar seu papel social em prol da questão racial. Considerando que há poucos artigos científicos que discorrem sobre a Pastoral, transcendendo ainda mais a importância em pesquisar sobre a mesma.

Os objetivos específicos da Pastoral Afro-brasileira, estão pautados nos ensinamentos de Jesus Cristo, que ensina o cristão a partilhar desde a dor e a fome, como os momentos de alegria, amor e sonhos, de acordo com considerações da CNBB. O referido diálogo inter-religioso também contempla os objetivos da PAB, pois, são as religiões de Matriz africana que guardam até os tempos atuais a cultura e identidade da população negra. "A Pastoral Afro atua, preferencialmente, no diálogo inter-religioso com a religião
de matriz africana. O africano é uma pessoa essencialmente religiosa. A
concepção religiosa africana é complexa. Para se compreender a visão de mundo
dos afro-brasileiros, faz-se necessário conhecer um pouco as culturas e as
religiões dos povos africanos". (CNBB, 2007, p. 22)

O contato com a sociedade civil que a Pastoral Afro-brasileira dispõe através da união com Grupos organizados, Movimento Negro e Movimentos Sociais, também são ressaltados na pesquisa, pois, ilustra a responsabilidade social que a PAB exerce. A articulação das ações concretas da Pastoral não permeia apenas a Igreja Católica, ela transpassa os muros da Igreja, conforme relatado por uma das articuladoras leigas da PAB de um dos núcleos do Rio de Janeiro, Dona Zica, que diz: "Sim, a PAB tem um papel social fora da Igreja".

A pesquisa também ressalta a responsabilidade social da Pastoral Afrobrasileira, pois, considero que ela é um dos fatores de maior importância para enfrentar a luta em prol da igualdade racial, visto que, o racismo não está inserido apenas dentro da Igreja Católica e não pode ser tido apenas como um problema da população negra. O racismo é uma questão social, que deve ser tratado minuciosamente, por afetar de maneira discriminatória diretamente aos 
negros, os excluindo legitimamente de oportunidades dentro da sociedade, sendo considerado o fundante das mazelas sociais do Brasil.

E para agir de fato nessa exclusão da população negra é necessário desenvolver ações concretas que viabilizem a conscientização em prol da igualdade racial. Para isso a Pastoral Afro-brasileira tem como protagonistas leigos, leigas e líderes religiosos que pensam e articulam atividades com o anseio de intervir nessa igualdade. Com isso, a pesquisa reconhece alguns desses principais personagens da PAB e traz considerações que visam o melhor entendimento, não só sobre a gênese da Pastoral, mas como também a dinâmica desenvolvida pelos membros da PAB.

A presente pesquisa foi de cunho qualitativo, com a perspectiva de responder questões que não podem ser quantificadas. Para Minayo, "a metodologia qualitativa trabalha com o universo de significados, aspirações, crenças, valores e atitudes, o que corresponde a um espaço mais profundo das relações, dos processos e dos fenômenos que não podem ser reduzidos à operacionalização de variáveis" ( 2002, p. 22). Assim como para Gil, que "tem como objeto proporcionar maior familiaridade com o problema, com vista a tornálo mais explícito ou construir hipóteses" (Gil, 2002, p. 41).

A abordagem técnica utilizada para coleta e análise dos dados através de entrevista semiestruturada, que de acordo com Gil (1999, p. 117) "é a técnica em que o investigador se apresenta frente ao investigado e lhe formula perguntas, com o objetivo de obtenção dos dados que Ihe interessam a investigação". Para essa abordagem técnica foram utilizados dois questionários de entrevista, um que será aplicado para os líderes religiosos e o outro que será aplicado para as leigas que são articuladoras das ações concretas da PAB.

As ressalvas trazidas pelos protagonistas visam explicitar o quão relevante é o envolvimento da Igreja Católica, para intervir nas expressões da questão social, citando nessa pesquisa enfaticamente como uma dessas expressões, a desigualdade racial. Principalmente considerando que a Igreja teve um importante papel no processo de escravização dos negros, a Pastoral é consumada também com o propósito de efetivar um pedido de desculpas a população negra que segue enfrentando preconceito e exclusão social.

E no decorrer da pesquisa, visando obter o maior número de informações sobre a construção da $\mathrm{PAB}$, visitei núcleos da Pastoral de três cidades do Brasil e durante essas visitas, tive o prazer de conversar com membros da Pastoral Afro-brasileira, que relataram acontecimentos e características da própria 
Pastoral. E embora, nem todos os membros tenham sido diretamente entrevistados, há na pesquisa pontos relevantes que discorrem sobre a gênese e a articulação da Pastoral Afro-brasileira.

Portanto, o último momento da pesquisa relata a partir do olhar dos protagonistas da Pastoral Afro-brasileira, qual a representatividade que a questão racial e a reflexão social têm em relação ao desenvolvimento das ações concretas da PAB. Expondo as considerações que leigos, leigas e líderes religiosos dispõem em relação as expressões da questão racial que assolam os negros até hoje e que influenciam a luta de Movimentos Sociais que se articulam em prol da igualdade racial. 


\section{Consideração histórica da constituição da Pastoral Afro- brasileira}

A Pastoral ${ }^{1}$ Afro-brasileira surgiu no ano de 1988, através da Campanha ${ }^{2}$ da Fraternidade (CF) da Igreja Católica, cujo título era "Fraternidade e o Negro" e o tema da campanha "Ouvi o clamor deste povo". A Campanha de 88 chamou a atenção para as demandas e vulnerabilidades do negro, que carrega consigo uma história de luta, resistência e persistência, tanto na sociedade quanto dentro da Igreja.

A PAB como é conhecida a Pastoral Afro-brasileira, integra o grupo da Pastoral Social da Igreja Católica, que tem como base de atuação os documentos da CNBB. O grupo da Pastoral Social atua em prol dos "excluídos", através das demandas sócio-transformadoras, identificadas nas comunidades locais, tendo como sua real inquietude, a qualidade de vida da população relacionada à saúde, educação, habitação, trabalho e a herança cultural (Cartilha da Pastoral Social 2001).

Setor Pastoral Social pretende fornecer pistas aos que atuam no campo tão vivo e complexo das mudanças sociais e políticas, sem esquecer, entretanto, que o mais importante é a criatividade e a espontaneidade de cada um no seu compromisso cristão. (BRAIDO, 2000, p. 05).

A Pastoral Afro-brasileira tem como metodologia de atuação, segundo estudos dos documentos da CNBB, o mesmo método das Pastorais Sociais, que é o do ver-julgar-agir ${ }^{3}$ tendo como alguns dos objetivos centrais de articulação:

\footnotetext{
${ }^{1}$ Pastoral: é toda a ação da Igreja e sua missão neste mundo. A Igreja não existe para si mesma, mas em função da sua missão de anunciar Jesus Cristo e fazer acontecer o Reino de Deus.

${ }^{2}$ Campanha da Fraternidade: é um dos preciosos dons com que Deus agraciou a Igreja no Brasil. Temos plenas condições de fazê-lo render muitíssimo mais em termos de processo evangelizador e também de sustento das atividades pastorais da CNBB Nacional e Regional, além do atendimento ao Gesto Concreto ligado ao tema de cada ano. (Texto base da Campanha da Fraternidade de 1988).

${ }^{3} \mathrm{O}$ método VER-JULGAR-AGIR é o método mais importante da Igreja Católica para realizar sua evangelização através das Pastorais. Essa metodologia é pautada no sentido de que ver, representa o conhecimento da realidade a ser transformada através da ação Pastoral. Julgar significa remeter essa análise feita da realidade para os valores cristãos, sem que haja préjulgamentos e pré-conceitos, ou seja, iluminar na fé e evangelização. E o agir, que é a ação concreta após essa reflexão, no objetivo de realizar uma transformação cristã.
} 
- Ajudar a Igreja a apoiar e a criar iniciativas contra o racismo, a discriminação, a exclusão do negro, assumindo posturas em defesa de seu patrimônio cultural, por meio de atividades concretas.

- Promover o diálogo entre indivíduos, a fim de que todos trabalhem juntos por uma sociedade mais justa.

- Articular fé e vida na construção da justiça social.

Porém, não há como discorrer sobre a gênese da Pastoral Afro-brasileira sem fazer um resgate histórico, principalmente a partir do período de 1964 a 1985, quando foi instaurado um grande momento de supressão de direitos civis e políticos no Brasil: Período da Ditadura Militar. Esse momento também impulsionou a formação da PAB.

José Geraldo da Rocha (1998) relata que a Ditadura Militar foi demarcada por repressões em todos os âmbitos sociais, fazendo com que ecoassem os Movimentos Sociais na década de 70. O mesmo, também ressaltou que esse período não impossibilitou a Igreja Católica de expandir sua atuação na questão social, o que fazia com que alguns movimentos sociais buscassem auxílio na Igreja para continuar suas intervenções.

O presente capítulo vai ressaltar a trajetória de criação da Pastoral Afrobrasileira, discorrendo sobre os marcos histórico da Igreja Católica que demarcaram o curso da concretização da Pastoral. Ressaltando também sobre as Conferências de Medelín e Puebla, que foram historicamente essenciais para que a Igreja instituísse seu olhar focalizado para as questões sociais que envolvem também a desigualdade racial dentro da instituição Igreja.

\section{1}

\section{Trajetória inicial da Pastoral Afro-brasileira}

A Igreja de uma forma única tem a missão de anunciar o evangelho. $O$ padre salesiano Ralfy Mendes de Oliveira (2004) ressalta que essa ação é denominada de evangelização, conforme sinaliza o próprio: "Entende-se por evangelização a ação apostólica-religiosa usada pela Igreja para revelar e comunicar aos homens o acontecimento salvífico de Cristo". 
Tendo em vista que a evangelização é uma das principais missões da Igreja Católica, descrevendo esse seu compromisso através de sinalizações feitas por teólogos, que dissertam sobre o papel evangelizador dessa instituição. Como por exemplo, considerações enfatizadas por Aquilino de Pedro Hernández (2004), que é teólogo e ressalta de maneira simplória o sentindo de evangelizar para a Igreja Católica, conforme a seguir:

\begin{abstract}
Entende-se por evangelizar o processo total mediante o qual a Igreja, o povo de Deus, movido pelo Espírito Santo: 1) anuncia ao mundo o Evangelho do Reino; 2) dá testemunho entre os homens da nova maneira de ser e de viver que ele [o evangelho] inaugura; 3 ) educa na fé os que se convertem a ele; 4) celebra na comunidade dos que crêem nele a presença do Senhor Jesus e o dom do Espírito Santo; 5) impregna e transforma com sua força toda a ordem temporal. (Pedro, 1993, p.110)
\end{abstract}

A Igreja Católica se debruça em evangelizar, assim como, se preocupa também em atuar nas demandas sociais, que causam desequilíbrio e injustiças. Salienta-se, portanto, que esses pleitos são frutos da degradação das relações de trabalho e das proteções sociais, que segundo Castel exemplificam o que é vulnerabilidade. E o descaso do Estado é uma das situações que provém essas demandas, fomentadas pelo sistema capitalista vigente, que nutre a desigualdade social, atingindo também a camada mais desprotegida socialmente.

Porém, essas desigualdades que contemplam as expressões da questão social não afligem apenas uma camada da sociedade, pelo contrário, esses desajustes que o Capitalismo proporciona que contribui para o aumento das desigualdades sociais, envolvem toda a sociedade. Cabendo assim, salientar que esse desequilíbrio social não é uma situação especial da camada mais vulnerável:

A desigualdade não é um fenômeno procedente apenas de questões econômicas e de diferença de classe, mas está condicionado a outras variáveis, como gênero, sexo, raça, etnia, entre outras. Entretanto, ainda há certa resistência, principalmente do meio acadêmico, em analisar a influência dessas variáveis na dinâmica das desigualdades sociais. (CLAPP, 2010, p. 137)

E dissertar sobre desigualdades e as fragilidades das degradações de direitos referentes ao âmbito social, faz lembrar um dos períodos mais repressores que o país já vivenciou, que foi a Ditadura Militar na década de 70. Durante esse período o país presenciou um extenso declínio de direitos trabalhistas e sociais, porém, segundo José Geraldo da Rocha (1998), a Ditadura Militar não impediu que a Igreja Católica intensificasse seu olhar e suas 
ações para o social, conforme proposto na Conferência Episcopal Latino Americana dos Bispos em Medellín em 1968, que será discorrido posteriormente.

O olhar da Igreja Católica para os Direitos Humanos foi potencializado na década de 70, após a Conferência Episcopal Latino Americana dos Bispos em Medellín através do grupo da Pastoral Social. As pastorais que compõem esse grupo visam o compromisso social, com o propósito de intervir nas dimensões sócio-transformadoras da ação evangelizadora da Igreja Católica no Brasil, segundo a Cartilha da Pastoral Social. Esse grupo é composto por pastorais que desenvolvem atividades em prol dessas transformações que são específicas para cada grupo em situação de vulnerabilidade.

A Pastoral Social, por sua vez, tem como objetivo desenvolver atividades concretas que viabilizem essa transformação em situações específicas, tais como o mundo do trabalho, a realidade das ruas, o campo da mobilidade humana, os presídios, as situações de marginalização da mulher, dos trabalhadores rurais, dos pescadores, e assim por diante. (CNBB, 2001, p.10)

Esse olhar para os Direitos Humanos é encontrado em documentos religiosos da CNBB, como o da própria Conferência Episcopal ocorrida em Medellín na década de 70 . No documento é relatado a opção da Igreja Católica em atuar numa perspectiva social, originando portando uma grande mudança no aspecto da Igreja e conseqüentemente o surgimento das Pastorais Sociais.

O nascimento do grupo das Pastorais Sociais foi demarcado por propostas especialmente direcionadas para a população em condição de vulnerabilidade social. Essas Pastorais atuam em algumas expressões da questão social, como saúde, educação, moradia e cidadania, segundo a Cartilha da Pastoral Social. Estão incluídas no grupo da Pastoral Social:

- Pastoral Operária (PO);

- Serviço Pastoral dos Migrantes (SPM);

- Conselho Pastoral dos Pescadores (CPP);

- Pastoral dos Nômades;

- Pastoral Carcerária;

- Pastoral da Saúde;

- Pastoral da Mulher Marginalizada (PMM);

- Pastoral do Povo da Rua;

- Pastoral Afro-Brasileira;

- Pastoral da Pessoa Idosa; 
- Pastoral da AIDS.

Entre as Pastorais Sociais existentes na Igreja Católica está a Pastoral Afro-brasileira, sinalizando a existência da desigualdade racial que é uma das expressões sociais mais latentes e veladas no país. E essa situação só se protela, porque a populaçãoprofere constantemente que o país vive em uma equidade racial. Porém, os militantes negros cristãos, atentaram e perceberam que a desigualdade racial estava presente até mesmo dentro da instituição Igreja, que deveria ser a mais igualitária por princípios cristãos de que todos são iguais.

A Pastoral Afro-brasileira busca a valorização do negro, com base nas demandas relacionadas a essa população, como por exemplo, evidenciar sua identidade, cultura e ancestralidade, com o intuito de intervir na desigualdade racial. Essas causas são provenientes dos resquícios deixados pela prática de exploração que o negro foi exposto durante décadas, ou seja, desde a escravidão e que assolam a população negra até hoje.

O surgimento da Pastoral Afro-brasileira foi inspirado na Conferência de Puebla (1979), que voltou o olhar da Igreja Católica para a questão racial, falando abertamente sobre as demandas do negro. O novo olhar da Igreja foi influenciado pelas reivindicações dos cristãos negros ativistas que se organizaram em grupos para discutir a questão racial, conforme será sinalizado na pesquisa posteriormente.

A militância dos cristãos negros foi essencial para a criação da Pastoral Afro-brasileira, pois foi através dos grupos organizados, a partir da Linha 2 da $\mathrm{CNBB}^{4}$ que o tema sobre a questão racial foi levado para a Conferência de Puebla e teve espaço dentro da Igreja Católica. Após a Conferência, os grupos se fortificaram e concluíram que deveria ser criada uma Pastoral que olhasse especificamente para as demandas advindas da população negra.

Os grupos dos cristãos negros ativistas se fortaleceram após a Conferência De Puebla e iniciaram a reivindicação para que a Campanha da Fraternidade (CF) da Igreja Católica de 1988, falasse sobre o negro e assim foi feito. A CF de 1988 teve como título "Fraternidade e o Negro" abrindo o leque para que a Igreja valorizasse a identidade do negro.

\footnotetext{
${ }^{4}$ Intitula-se: Linha2 da CNBBo grupo criado em setembro de 1978 em Brasília por estudiosos, que estavam preocupados com a evangelização dos negros, afim de elaborar estudos sobre 0 culto afro para que os Bispos levassem para a Conferência de Puebla.
} 
José Geraldo da Rocha (1998) enfatiza que a Campanha da Fraternidade de 1988 foi bem-sucedida. Mesmo com todas as ressalvas, discussões e divergências, por tratar de um tema jamais abordado dentro da Igreja Católica, a CF obteve sucesso. E através desse feito, a Igreja iniciou uma reflexão sobre a situação do negro, que historicamente demonstrou resistência a todos os desafios impostos pela sociedade.

A Igreja Católica visava não só chamar a atenção para as demandas do negro na sociedade, mas também almejava agir nas suas vulnerabilidades, como a desigualdade racial, racismo, preconceito e discriminação, utilizando a Campanha da Fraternidade de 1988 como um instrumento reivindicador. Seu intuito era contribuir para o melhor entendimento do cristão leigo sobre a questão racial e a identidade do negro, transparecendo a sua atualmente responsabilidade em relação à questão racial, ou seja, à inclusão do negro.

Toda a movimentação e articulação provenientes da Campanha da Fraternidade de 88 teve um resultado. Após esse período, instituiu-se na Igreja Católica, a Pastoral Afro-brasileira, que visa até o presente momento à valorização da cultura afro, ressaltando a identidade negra e a luta contra o racismo, através de ações concretas (Cartilha da Campanha da Fraternidade de 1988).

Após o desenvolvimento da Campanha da Fraternidade de 88, ficou ainda mais latente que a Igreja Católica precisava de uma pastoral que visasse o acolhimento do negro na instituição e discorresse sobre sua identidade, cultura e ancestralidade. Essa questão impulsionou líderes religiosos negros a lutar por uma pastoral que ressaltasse as demandas da questão racial. Essa vontade fez com que assuntos relacionados aos negros continuassem latentes dentro da Igreja.

A Pastoral Afro, Portanto, está tentado transcender o espaço que the fora reservado, a promoção social do negro, ao querer intervir na liturgia (principalmente da missa), colocando elementos considerados próprios da cultura afro-brasileira. É, portanto, nessa tensão entre "sala" e "cozinha", isto é, intervenção no rito litúrgico e a promoção social, que se encontra esse grupo. Esse aspecto se mostra já na constituição do grupo, tanto em Salvador quanto em São Paulo. (Oliveira, 2011, p. 91)

Conseguinte a Campanha da Fraternidade de 88 , o vulto em relação à questão racial tomou grande proporção dentro da Igreja Católica. Porém, há divergência em relação ao início da Pastoral Afro-brasileira. Documentos da Igreja como o texto base da Campanha da Fraternidade de 88, aponta que o início da PAB, foi quando Dom Helder Câmara realizou a missa para os 
quilombos, na década de 1970. Porém, o Documento da CNBB 85, sinaliza a CF de 88 como o início da Pastoral Afro-brasileira.

De acordo com o Padre Jurandyr, assessor nacional da Pastoral Afrobrasileira, a movimentação em relação ao debate sobre a questão racial dentro da Igreja Católica iniciou antes da Campanha da Fraternidade de 88. O mesmo relata que "A Pastoral Afro-brasileira nasceu de um grito que houve em 1978 na Missa em São Paulo. Pe. Toninho depois da Missa gritou "vamos iniciar a pastoral?". Porém, Padre Jurandyr demarca a CF de 88 como um marco para o surgimento da PAB, pois foi através dos debates provenientes dessa Campanha que o negro teve mais notoriedade dentro da Igreja Católica.

A declaração do assessor nacional da Pastoral Afro-brasileira corrobora a fala de alguns líderes religiosos negros, que conhecem a história de militância do então referido Padre Toninho5, que se chamava Antônio Aparecido da Silva, era reconhecido entre os membros da PAB como patriarca Pastoral. Os membros da Pastoral atrelam o seu surgimento a mobilização do referido Padre em prol da população negra, dentro da Paróquia Nossa Senhora Achiropita, que se localiza na cidade de São Paulo, no bairro do Bixiga.

A sua impulsão pela questão dos negros, consumou-se através de encontros, debates e o surgimento da própria PAB, demarcando espaço e consciência negra, conforme sintetiza Rosangela Borges (2001). O líder religioso nasceu no dia 28 de novembro e aos 61 anos faleceu, precisamente no dia 12 de dezembro de 2009, vítima de um derrame, conforme relatos dos atuais membros da Pastoral Afro-brasileira Achiropita.

A criação da Pastoral Afro-brasileira dentro da Paróquia Nossa Senhora Achiropita era um sinal de resistência do negro cristão. Padre Toninho era um grande articulador da questão racial na cidade de São Paulo, ele conquistava a todos com seu carisma e entende-se que isso foi um diferencial para que o patriarca tivesse êxito no seu objetivo de criar a PAB em uma instituição que cultua até hoje os valores e costumes eurocêntricos.

A Pastoral Afro-brasileira além de estimular a espiritualidade do negro cristão, tem o intuito de destacar a cultura afro, com o propósito de colaborar para que o negro assuma sua negritude e entenda melhor sua afro

\footnotetext{
${ }^{5} \mathrm{~A}$ informação sobre o Padre Toninho foi obtida através da entrevista realizada pela pesquisadora com membros da Pastoral Afro-brasileira Achiropita
} 
descendência. Esse estímulo ocorre através de estudos em reuniões e ações concretas em prol das demandas da questão racial. O diálogo e a participação em ações com o grupo da Pastoral Social, também se torna uma forma de disseminar e expor a cultura da população negra.

As ações da Pastoral Afro-brasileira não se caracterizam apenas pelo estudo de documentos e subsídios oficiais da Igreja Católica, pelo contrário, a PAB desenvolve uma grande articulação para difundir a identidade negra, com o objetivo de sinalizar para o negro a importância de conhecer sua própria história. As ações concretas que a PAB articula, vão muito além do estímulo à vivência da espiritualidade dentro da Igreja Católica, elas colaboram para que o negro cristão viva sua afro descendência também no âmbito social.

No período da Campanha da Fraternidade, a militância dos negros cristãos dentro da Igreja Católica teve o intuito de chamar a atenção para as suas próprias demandas, pois, até hoje sofrem os reflexos deixados pelo período da escravidão. E é com base nesses reflexos que a Pastoral Afro-brasileira vai intervir através de ações que evidenciem a identidade negra, cooperando para a igualdade racial dentro da Igreja Católica, assim como no âmbito social, através das suas ações junto aos movimentos sociais.

A articulação da Pastoral Afro-brasileira em prol da igualdade racial revela uma das missões da Igreja Católica, que é atuar na realidade "dura e cruel" em que vive a população negra, até mesmo em virtude da sua postura no período da escravidão, quando foi conivente com a prática social de exploração que o negro foi submetido. Segundo os princípios de orientação da Pastoral Afrobrasileira, a Igreja deseja construir uma comunidade de fé e identidade, tornando os negros mais participantes dentro da lgreja após os longos anos de exclusão.

De acordo com a CNBB, o reconhecimento da realidade do negro, também é um dos objetivos da PAB, que se estabelece através da organização e planejamento de encontros, exposições, cursos de formação, passeios em lugares que remetem a história do negro, participação em eventos que evidenciam a luta dos grupos denominados como excluídos e que desenvolvem ações contra a intolerância religiosa.

Animar os grupos negros católicos para o resgate da sua verdadeira história; Incentivar o surgimento de novos grupos que buscam sua identidade numa sociedade e Igreja plurais; Promover integração e articulação dos grupos e das iniciativas, respeitando as suas particularidades; Colaborar na construção de uma sociedade justa e solidária. Como exercício da cidadania, a serviço da vida e da esperança; e Testemunhar a fé em profunda comunhão eclesial. (CNBB, 2002, p. 44)

Essa sinalização que a CNBB remete, revela o quão importante são as celebrações inculturadas. Que implicam em um método de acrescentar cultura ou 
aspecto culturais de um determinado povo, que proporciona transparecer que a Igreja compreende que todas as experiências cristãs devem exprimir relações justas, estabelecendo o bem-estar de todos os seres e representatividades, segundo Marcelo Azevedo (2001).

"Inculturação se mostra, então, como um duplo movimento: por um lado, a experiência evangélica influi nas culturas, tanto no sentido de sua libertação, como de desenvolvimento de suas potencialidades humanizadoras; por outro, as culturas também influem na experiência cristã, na compreensão e na prática do Evangelho, alargando e enriquecendo a tradição cristã, bem como desconstruindo interpretações da revelação percebidas como distorção da imagem de Deus que Jesus nos mostra." (Azevedo, 2001, p.60)

A Pastoral Afro-brasileira se propõe prioritariamente a difundir a identidade do negro e ressaltar a sua importância na formação social do Brasil. Além de respeitar sua religiosidade, que traz toda a cultura e ancestralidade, como as religiões de Matriz Africana, que são tidas na maioria das vezes como algo negativo, colaborando ainda mais para o olhar estereotipado do negro.

A importância de analisar a gênese e a articulação da Pastoral Afrobrasileira se contempla também, através da sua interação e participação em ações sociais com a comunidade local, por meio do grupo da Pastoral Social e Movimentos Sociais. Esse contato permiti uma maior aproximação da população em situação de vulnerabilidade social, que na sua maioria é composta por negros, tornando o papel da PAB, fundamental na disseminação da cultura e identidade negra.

A Pastoral Afro-brasileira pode ser considerada um agente social, por ser capaz de intervir nas questões relacionadas à desigualdade racial e por ampliar o espaço de questionamentos e diálogos, que é central no processo de construção da identidade racial. Esse espaço possibilita a família que milita na $P A B$, ser considerado também um instrumento para a construção da identidade racial, pois, dialoga sobre a importância da história dos negros e ressalta sua inculpabilidade no processo da escravidão, por enfrentar toda a situação de discriminação e violência que o regime de exploração os expôs.

Com isso, a Pastoral Afro-brasileira também é tida como um instrumento essencial para que o negro tenha acesso a sua história e possa entender porque estão expostos a certas situações discriminatórias dentro das relações sociais. Possibilitando uma maior reflexão sobre seu papel enquanto negro e perceber que são capazes de encontrar-se em qualquer espaço do âmbito social.

Buscando ainda compreender a proposta central da Pastoral Afrobrasileira, deve-se ressaltar a religiosidade do negro. Alguns estudos como o do 
líder religioso da Igreja Católica e militante dos Direitos Humanos, Frei Davi Raimundo dos Santos (2014) consideram que a religiosidade do negro durante muitos anos, não foi tida como importante para a Igreja Católica. Tendo em vista que essa instituição foi conivente com o genocídio provocado pela colonização européia no período da escravidão, garantindo a cultura tradicionalista da Igreja de não abranger culturas diversas.

O negro é um ser permeado de religiosidade e essa afirmativa pode ser comprovada através das religiões de Matriz africana, conforme ressalta Frei Davi Raimundo dos Santos (2014), em um dos seus artigos. O Frei ainda afirma que a Igreja Católica durante anos não se importou com as demandas da desigualdade racial expostas na sociedade, que discriminava o negro, os denominando como seres sem alma e amaldiçoados.

"Se a Igreja católica não Ihes permite espaço, buscam, sem perda de tempo, exercer sua fé verdadeira e legítima em outras expressões religiosas. A religião está à flor da pele deste povo negro" (Raimundo, 2014, p. 01)

Essas considerações evidenciam a não preocupação da Igreja Católica, em relação a religiosidade do negro, concentrando suas ações concretas apenas na situação social a que o negro está exposto. Mesmo que tenha sido feito pela população negra, um sincretismo entre os Santos do catolicismo com seus Orixás, apresentando entre eles, de acordo com as explicações dos negros uma grande sintonia, por entender que é na religiosidade que se conserva a maior parte da cultura afro e o quanto essas religiões representam a resistência da população negra.

Cabe, portanto, ratificar que a religião além de representar uma doutrina, ela também agrega valores culturais, além de expressar uma força civilizatória de um "povo". Através dessa sinalização, compreende-se a necessidade de realizar as Missas Inculturadas, que são denominadas como ações concretas que a Pastoral Afro-brasileira desenvolve, ressaltando toda a ancestralidade da população negra, contribuindo até mesmo para a amplitude do diálogo interreligioso.

O Documento de subsidio de estudo da Regional Nordeste ${ }^{6}$, relata queum diferencial da Pastoral Afro-brasileira é atuar através do diálogo inter-religioso, pois a interação e articulação com o outro faz com que seja desenvolvido o respeito, acolhimento e atenção recíproca, formando assim, consciência de unidade, estando aberta para todas as pessoas, sejam cristãos ou não, sem

\footnotetext{
${ }^{6}$ Documento "Pastoral Afro-brasileira - Subsidio de Estudo e Formação para Agentes de Pastoral Afro" da Regional Nordeste 3 - CNBB (Bahia e Sergipe)
} 
distinção alguma. Entretanto, o foco central de ação da PAB está no campo da questão racial.

Tendo em vista que a Igreja Católica assim como toda a sociedade brasileira sofre influência da cultura européia, o desafio da Pastoral Afrobrasileira se amplia ainda mais. Principalmente no momento em que a PAB destaca a ancestralidade e demonstra a religiosidade do negro na oração através das Missas inculturadas, trazendo elementos da cultura afro, conforme sinalizava o patriarca Padre Toninho.

Visto que a religiosidade do negro é aflorada, a Pastoral Afro-brasileira entende que a realização das Missas inculturadas é uma das ações concretas que evidenciam a identidade negra. Pois, a inculturação das celebrações é uma das maneiras mais pertinentes de apresentar para a Igreja Católica a cultura que o negro possui. Mesmo que exista grande resistência de diversas paróquias em aceitar essa exposição da ancestralidade do negro nas Missas, por assimilar com o culto de religião de Matriz Africana, a PAB prioriza essas celebrações inculturadas, conforme assinala o manual da Campanha da Fraternidade 1988.

Desta forma, cabe tornar notável um dos marcos histórico da Igreja Católica que possibilitou a inserção do ecumenismo, possibilitando o diálogo inter-religioso com acultura afro. Esse marco foi o Concílio Vaticano $\mathrm{II}^{7}$, que ocorreu no ano de 1962 e se perpetuou até 1965, com o propósito de aproximar a Igreja das transformações do mundo moderno e possibilitar o diálogo da lgreja com religiões que não são cristãs.

O Concílio Vaticano II, também tinha a finalidade de reconquistar os cristãos que haviam se afastado da Igreja Católica. Favorecendo um novo rumo para a Igreja do mundo inteiro, possibilitando experiências eclesiais novas e abrindo espaço para uma instituição mais direcionada ao campo social, que se encontrava deflagrada pela realidade sociopolítica e principalmente econômica.

De maneira bem genérica é possível destacar três grandes vértices norteadores verificados na proposta de renovação teológica-pastoral do Concílio Vaticano II:

1) diálogo da igreja com o mundo moderno, 2) diálogo da Igreja com as religiões nã0-cristãs; 3) nova auto compreensão da Igreja e nova missão universal - a Igreja que se compreendida como sociedade perfeita e como poder, agora se

\footnotetext{
${ }^{7}$ Os Concílios são momentos de revisão, afirmação e transmissão da tradição da Igreja feitas pelo Magistério que, em seu múnus de ensinar, exerce o mandato evangélico de levar a mensagem da Boa-Nova a todos os povos (cf. Lc 24,47-48), sob a guia do Espírito que conduz os discípulos à verdade (cf. Jo 16,13) e a coordenação primeira do sucessor de Pedro, a quem compete confirmar os cristãos na fé (cf. Lc 22,32) em comunhão com o colégio apostólico dos bispos de toda a lgreja.
} 
compreende como comunidade e serviço, ou seja, Igreja se compreende como comunidade e serviço, ou seja, Igreja como povo de Deus. (Borges, 2001, p. 124)

Portanto, é importante destacar que os objetivos concluídos no Concílio Vaticano II, foram relevantes para a questão da inculturação afro na Igreja Católica. Pois, segundo o subsídio para agentes de Pastoral Afro, a inserção dos elementos afronas celebrações, não tem o propósito de entrar em conflito com a sociedade e muito menos com a comunidade eclesial. Pelo contrário, a finalidade dessa ação concreta da Pastoral Afro-brasileira é propagar a cultura de uma população que faz parte da sociedade, conforme a população negra, que passa por constante supressão de direitos, inclusive de expressar sua cultura.

Cada povo tem seus costumes e isso deve ser respeitado em qualquer âmbito social, impreterivelmente dentro da Igreja Católica, mesmo tendo ela seus valores eurocêntricos. Inclusive sabe-se que a população indígena e afro dispõem de uma cultura milenar, que tem seus valores incalculáveis socialmente, por possuir grande riqueza cultural.

A palavra Cultura, no sentido lato, designa tudo aquilo com que o homem apura e desenvolve os inúmeros dotes do corpo e do espírito... e torna mais humana a vida social, tanto na família como em toda comunidade civil...; formula, comunica e conserva as grandes experiências espirituais e as aspirações maiores do homem (GS 23) (Ciscato, 1989, p. 15).

Antes do Concílio Vaticano II (1962 - 1965), a Igreja Católica tinha imponderavelmente uma definição de cultura, com base nos costumes europeus, que extinguia qualquer tipo de cultura diferenciada, como por exemplo, a cultura afro nas Missas. Porém, através do objetivo do II Concílio, a Igreja se abriu para absorção das diversas culturas, expressando então, a importância de dialogar com os sistemas culturais, com o intuito de fazer com que a evangelização não seja apenas um verniz.

O Concílio Vaticano II permitiu que a Igreja Católica percebesse que a inculturação é denominada como "sinais dos tempos"8 e que ela proporciona um melhor entendimento da riqueza da realidade do outro, permitindo aprender com eles. Esse fato intervém e colabora para que haja uma troca, ou seja, através do diálogo é capaz de aprender e ensinar concomitantemente, a humildade advinda do processo de inculturação e do reconhecimento dos valores de cada realidade.

\footnotetext{
${ }^{8}$ Sinais dos tempos são todos os fatos, acontecimentos e situações que podem indicar a intervenção ou presença transcendente de Deus, querendo estabelecer diálogo com os seres humanos em sua realidade.
} 
Considerando a importância da inculturação através das celebrações, o patriarca Padre Toninho ressalta que a aproximação com a cultura afro, através das Missas inculturadas é importante para demonstrar que a Igreja Católica respeita e preza pelos costumes e valores do negro dentro da instituição. O patriarca afirma também, que o novo gera desconfiança, opiniões divergentes, medo, estranhamento e foi exatamente dessa forma que aconteceu com a Pastoral Afro-brasileira. Padre Toninho enfrentou muita adversidade, contratempos, discriminação, mas se manteve firme no propósito de fazer com que o negro se sentisse membro de uma instituição totalmente eurocêntrica e conivente com o período da escravidão.

Mesmo contando com a anuência do papa, a liturgia inculturada ainda encontra resistência de muitos padres, que não a aceitam, gerando momentos complicados. Veja então que é uma luta constante, altamente conflitiva. (Toninho, 2013, p. 05)

A inculturação nas celebrações irá influenciar e potencializar a auto estima da população negra, de acordo com a $\mathrm{Sr}^{\mathrm{a}} \mathrm{A}^{9}$, outra importante liderança da Pastoral Afro-brasileira Achiropita. Ela afirma que a aproximação e reconhecimento da ancestralidade da população negra dentro da Igreja Católica, irá proporcionar para os negros cristãos um maior domínio sobre as questões ligadas à sua origem, a fim de construir um debate mais consistente sobre sua história e trajetória.

A construção desse debate em torno da história da população negra deve ser arquitetada também através do diálogo inter-religioso, proporcionando o acolhimento da alteridade. Principalmente por entender, que o diálogo entre as religiões é uma construção, que busca uma melhor forma de respeitar ao próximo, conforme discorre o Padre Jurandyr Azevedo Araújo (2004).

Compreendendo que as religiões de Matriz africana carregam toda a cultura, ancestralidade e religiosidade do negro, torna-se pertinente um maior diálogo entre as religiões, como Umbanda, Candomblé e a Igreja Católica. A Pastoral Afro-brasileira, através das suas ações concretas em prol da igualdade racial, também viabiliza uma maior interação entre as religiões, com o propósito de ressaltar a diversidade e riqueza que cada religião se permeia.

"A Conferência Nacional dos Bispos (CNBB) define diálogo inter-religioso como o diálogo inter-religioso como o diálogo e a manifestação de fraternidade com pessoas e instituições de outras religiões não cristãs. Indicam, assim, que os

\footnotetext{
${ }^{9}$ Depoimento de entrevista realizada pela própria pesquisadora, com a Senhora Cândida na Paróquia Nossa Senhora de Achiropita.
} 
valores humanos, éticos e religiosos nelas, como também, em base à nossa fé, procuram fazer o bem a todos e trabalham juntos em projetos e ações de promoção do bem comum. A CNBB tem comissões de diálogo entre católicos e judeus, católicos e islâmicos, católicos e religiões afro-brasileiras". (Araújo, 2004, p. 57)

O propósito do diálogo inter-religioso se assemelha com a finalidade das ações concretas que a Pastoral Afro-brasileira almeja ao interagir com o próximo, que é o convite a sair de si e ir ao encontro do outro, de perceber e aceitar as diferenças. Posto que cada "povo" tem sua particularidade, João Paulo II (1991) ressalta sobre o diálogo inter-religioso que "O interlocutor deve ser coerente com as próprias tradições e convicções religiosas e ser disponível para compreender as do outro, sem dissimulações nem restrições, mas com verdade, humildade e lealdade, sabendo que o diálogo pode enriquecer a ambos".

E é nessa mesma perspectiva que o atual Papa da Igreja Católica, discorre sobre a relação de interação entre as religiões. Papa Francisco (2013) relata que o diálogo é o caminho para o respeito e a amizade, caracterizando essa ação como um caminho alternativo para encarar o medo que ainda assola pessoas de religiões diversas. Expondo também, que a prática de dialogar com as diferentes religiões, não faz com que percamos a própria identidade, pelo contrário, nos proporciona um crescimento fraterno com o outro, capaz de compreender e respeitar as diferenças.

O futuro encontra-se na convivência respeitosa das diversidades, não na homologação a um pensamento único, teoricamente neutral. Vimos durante muito tempo na história a tragédia dos pensamentos únicos. Por isso, torna-se imprescindível o reconhecimento do direito fundamental à liberdade religiosa, em todas as suas dimensões. (Francisco, 2013, p.138)

Decorrente das considerações expostas entende-se que o grupo das Pastorais Sociais, o que inclui a Pastoral Afro-brasileira, de acordo com documentos da CNBB, desfruta do desafio de responder às necessidades humanas em nome do Evangelho. Sendo a PAB, um ponto de apoio dentro da Igreja Católica contra o racismo e todas as manifestações de desigualdade racial, que tem o propósito de não mais excluir a população negra, anunciando posturas em defesa do patrimônio cultural e histórico por meio de ações concretas. 


\section{2}

\section{Um novo olhar da Igreja para a questão social}

A Pastoral Afro-brasileira percorreu um longo caminho até se conceber de fato dentro da Igreja Católica como um instrumento de luta contra a desigualdade racial. E para dissertar sobre a gênese da PAB é necessário analisar marcos histórico que foram essenciais para a construção do diálogo sobre a questão racial dentro da Igreja como a Conferência Episcopal Latino Americana dos Bispos em Medellín, que ocorreu precisamente no ano de 1968.

De acordo com as reflexões advindas do Documento da CNBB, que se refere as conclusões da Conferência de Medellín como é conhecido pelos católicos, o intuito era de buscar formas renovadoras e mais intensa da Igreja Católica, referente às transformações em que a América Latina estava vivendo naquele momento.

A Conferência de Medellín significou um grande marco para a Igreja Católica na América Latina, pois, a partir desse momento, a Igreja optou por voltar seu olhar para os Direitos Humanos, mais especificamente para os pobres. A Conferência fixou seu olhar para as necessidades de cada um, ou seja, para a especificidade de cada população relacionada à demografia, família, saúde e educação. Exercendo ações concretas e tendo a preocupação humana como principal fator de renovação a serviço do homem, através também da evangelização.

Frente às ações evangelizadoras, o maior propósito da Conferência de Medellín é transparecer que a responsabilidade de evangelizar e de se preocupar com as questões que envolvem as demandas sociais, não deve ser só dos Bispos, mas sim de todo "povo de Deus". Desta forma, o Documento de 85 da Igreja Católica, ressalva que a juventude é o símbolo de esperança, enxergando os mesmos como instrumentos de constante renovação da vida humana.

\footnotetext{
"Recomendam as conclusões de Medellín: a) que se apresente com mais nitidez a face de uma Igreja autenticamente pobre, missionária, pascal, audazmente comprometida na libertação do homem todo e de todos os homens; b) que a pregação e os documentos pastorais sejam simples e atualizados; c) que o sentido de autoridade se expresse em caráter de serviço; d) que haja uma autêntica orientação vocacional, levando em conta os diferentes estados da vida". (CNBB, 2007, p. 150)
} 
A Igreja Católica viveu um momento de bons frutos durante o intervalo do Concílio Vaticano II e a Conferência de Medellín, enaltecendo as mudanças da orientação pastoral e proporcionando que a Igreja seja tida como a "Igreja dos pobres". Agindo em prol da realidade vivida na América Latina naquele momento, como injustiça, desigualdade, opressão imposta pelos militares e pobreza, originando, portanto, a opção da lgreja pelos pobres.

Tendo a Igreja Católica optado pelos pobres nesse momento, a Conferência de Medellín conforme já fora mencionado, resultou no surgimento das Pastorais Sociais, com o propósito de assumir uma responsabilidade concreta em virtude das tensões sociais. No documento de Medellín, encontrase a preocupação dos Bispos em evidenciar em suas pregações, liturgia e catequese, o comprometimento com a dimensão social e comunitária, com o intuito de formas "homens" comprometidos com a construção de um mundo de paz.

A Conferência de Medellín facilitou a criação do grupo que formou a Teologia da Libertação ${ }^{10}$ dentro da Igreja Católica, essa reflexão teológica teve início de fato no ano de 1971, através de alguns teólogos como Leonardo Boff e do Padre Gustavo Gutiérrez. Essa teologia tinha como propósito fazer a união da Igreja Católica com os pobres, segundo o teólogo, citado por Rosângela Borges (2001).

A Teologia da Libertação pode ser compreendida como um novo modo de fazer teologia, que tem como principal objetivo a libertação dos pobres, redescobrindo a caridade e a espiritualidade a partir da realidade da periferia e de seu sujeito antropológico, o pobre. "(...) na raiz do método da Teologia da Libertação se encontra o laço com a prática concreta. É dentro dessa dialética maior da Teologia (da fé) e Práxis (da caridade) que atua a Teologia da Libertação". (Boff, 1993, p. 37)

Embora a preocupação da Conferência de Medellín seja os pobres, injustiçados, oprimidos e a população que vive em situação de desigualdade, a palavra negro, não foi mencionado no Documento de Medellín. O que sinaliza ainda mais, a necessidade de existir dentro da Igreja Católica uma Pastoral que agisse em prol das demandas expostas pela a população negra. Principalmente em virtude da postura que a lgreja teve em relação ao período da escravidão e da invisibilidade que a mesma tratava as questões relacionadas aos negros.

\footnotetext{
${ }^{10}$ Segundo Rosangela Borges (2001), "a Teologia da Libertação é filha da Igreja com os pobres", foi um grupo fundado por teólogos e padres.
} 
Com isso, os compromissos instaurados na Conferência de Medellín, foram renovados no ano de 1979, na III Conferência Geral do Episcopado Latino-Americano, que ocorreu em Puebla. A Conferência de Puebla, conforme é conhecida pelos cristãos católicos, reafirmou a responsabilidade da Igreja Católica em olhar preferencialmente para o pobre, assim como para o jovem. Essa afirmativa é constada nas conclusões da própria Conferência (texto oficial).

$\mathrm{Na}$ quarta parte das Conclusões de Puebla, em 1979, tratando da Igreja missionária a serviço da evangelização na América Latina, o episcopado faz duas opções que marcaram a Conferência: a opção preferencial pelos pobres (32 citações) e pelos jovens (40 citações).

Através da articulação dos negros religiosos, foi criado um "grupo de estudos sobre as questões afro-brasileiras" que visava essa Conferência, que se deu através da movimentação da Linha 2 da CNBB em 1978. O texto oficial da Conferência de Puebla, que era tido como o instrumento de criatividade e trabalho dos participantes, ressalta que o propósito da mesma era proclamar a dignidade da pessoa humana, corroborando para a defesa dos direitos fundamentais do homem na América Latina.

Chegou-se a formar um "grupo de estudos sobre as questões afro-brasileiras" com vistas a Puebla, integrado por alguns negros e negras, sobretudo de congregações religiosas, com a presença da Linha 2. Na reunião realizada por este grupo, em São Paulo, em dezembro de 1978, conclui-se que a Linha 2, enquanto presença de CNBB, assumia o compromisso de "incentivar e apoiar as reuniões específicas de padres religiosas e leigos negros. (Silva,1993, p. 3)

José Geraldo da Rocha (1998) aponta que o Documento da Conferência de Puebla abriu caminho para o diálogo sobre a questão racial dentro da lgreja Católica, surgindo então o denominado "grupo tarefa". Esse grupo tinha a missão de desenvolver um trabalho de conscientização das questões sociais em que o negro estava exposto em relação às desigualdades relacionadas à sua história, tais como: cultura, política e situação econômica.

Tendo em vista que a Conferência de Puebla tinha como intuito, a evangelização concreta das pessoas humanas e grupos sociais, enfatizava ações como:

- À tomada de consciência da situação em que cada um se encontra

- O compromisso como, por exemplo, da vivência da justiça e solidariedade

- À busca da libertação que vai além dos limites temporais

-A ação com todas as dimensões do mandamento novo, que é amor inteligente e crítico 
Essas ações tidas como evangelização concreta pelos Bispos que estavam trabalhando na Conferência de Puebla, tinham como foco central de atuação, os setores que a Igreja Católica identificava com mais necessidade de evangelização. Dentre os mais "necessitados" estavam os indígenas, a juventude, a família (a mulher), o mundo operário, os camponeses, até mesmo os meios de comunicação social e os Afro-Americanos. A Conferência tinha como princípio a participação e comunhão, para que assim chegassem a uma verdadeira libertação.

Para o Doutor em teologia Padre Beni dos Santos (1979) o Documento de Puebla relata um momento histórico para a Igreja Católica, nele a pobreza é vista como sinônimo de exploração e situação desumana, ou seja, ela é considerada uma dimensão sociopolítica estrutural. A pobreza é considerada o resultado das estruturas econômicas, políticas, sociais e não é transitória.

"O documento usa o termo "pobre" no sentido bíblico de anawin: o curvado, o oprimido. O termo tem, na Bíblia, uma conotação político-social. Designa o escravo, o estrangeiro, o perseguido, o cativo. Não se trata, pois, do simples necessitado, mas do oprimido, do explorado. Não designa apenas o indivíduo, mas a classe social explorada, a raça marginalizada, o grupo oprimido" (Santos, 1979, p. 59)

Nesse momento da Conferência de Puebla, a Igreja Católica identificou a necessidade de falar sobre a questão racial, de entender que a discriminação, o preconceito e o racismo ainda se faziam presentes dentro da instituição. Esses encontros foram de suma importância para se pensar em um reparo social, condizente com os reflexos deixados pela escravidão dentro da Igreja, agregando também a missão evangelizadora, pois a questão racial assola todos os âmbitos sociais.

- A Conferência de Puebla foi um diferencial para a Igreja Católica, pois, contribuiu para o estreitamento na relação da Igreja com o negro no Brasil, porque foi a partir da Conferência que surgiram as primeiras articulações dos negros cristãos dentro da Igreja, como por exemplo, o APN (Agentes de Pastorais Negros).

- O grupo formado após a Conferência de Puebla, denominado de "grupo tarefa", se estabeleceu no seu primeiro encontro, que foi em 1980 na cidade de São Paulo, com a finalidade de debater sobre a questão racial dentro da Igreja Católica, tendo os padres, religiosos negros e agentes de pastorais leigos como principais membros. Essa decisão foi acertada após a ideia do levantamento sobre a 
temática racial dentro da Igreja, sugerida nos encontros desse "grupo tarefa", pois a maioria dos padres negros não tinha consciência da sua negritude, proveniente do processo desenvolvido através do eurocentrismo existente na religião cristã, segundo José Geraldo Rocha (1998).

Do referido "grupo tarefa", culminou um encontro que ocorreu em 1981, onde foi criado o Grupo de União e Consciência Negra (GRUCON). O grupo discutia propostas para evidenciar a história do negro, enfatizando sua resistência durante todo o período da escravidão e tinha também o propósito de incluir nas celebrações elementos da cultura afro, assim como continuar o vínculo com a Linha 2 da CNBB. (ROCHA, 1998)

O debate sobre a necessidade de ser criada uma Pastoral Negra ganhou mais corpo no período de 1981 a 1982, surgindo assim indagações sobre como seria criar uma Pastoral dentro da Instituição que foi conivente com a escravidão? A questão central que se coloca é: será que esse fator não poderia atrapalhar a luta em prol da negritude e haver certa manipulação da parte da Igreja? E em meio ao conflito de ideais, ocorreu uma divisão do GRUCON, transformando-se em dois subgrupos:

Numa posição encontrava-se pessoas para abordar a questão racial no interior da Igreja. Do outro lado estavam os que pensavam e defendiam a independência enquanto grupo negro na abordagem da questão, em relação à Igreja. Estas duas posições gestaram os Agentes de Pastorais Negros propriamente ditos. (Rocha, 1998, p. 80)

Esta divisão foi resultado da ruptura do grupo, quando em 1983, deu-se início às atividades do Agente de Pastoral Negro (APN), assumindo um contexto de movimento negro, por militar em prol da negritude e pela fé. O APN executava atividades para a comunidade negra, sem deixar de se unir a outros movimentos negros, conforme dito por José Geraldo da Rocha (1998). A luta contra o racismo teve o foco principal das atividades do APN, sem se unir a nenhum partido político e nem se preocupar em fazer adeptos para sua religião, seu arcabouço era agregar membros para a luta contra a discriminação racial.

“(...)Esse grupo parecia corresponder às expectativas da Igreja, mas a ênfase dada ao ecumenismo, principalmente com as religiões afro-brasileiras, que até então não eram bem vista pela sociedade (é preciso lembrar que 16 dioceses não aceitaram o tema da CF/1988), fez com que a CNBB propusesse a criação de uma pastoral específica. (Oliveira, 2011, p. 78)

O Padre Antônio Aparecido da Silva (1993), no seu artigo "APNs: A presença Negra na Igreja" relata que há no Brasil um catolicismo com cor e essa cor é negra, demarcado pelas Irmandades de Nossa Senhora do Rosário, das 
Mêrces, de São Benedito e outras mais, que levam títulos diferentes. Essas instituições foram importantes para os negros, pois eram espaços de organizações dessa população e que hoje ainda recebem muitos negros e descendentes de escravos. Porém, essa demarcação não apaga a trajetória de discriminação que o negro sofreu dentro da Igreja Católica.

Conforme já fora mencionado, a lgreja Católica não se posicionou contra a prática de exploração do período escravista que marcou a trajetória do negro, com discriminação, desigualdade e opressão. E mesmo que hoje tenham ocorrido mudanças na Igreja em relação ao tratamento com o negro, os movimentos que lutam em prol da igualdade racial, como o Movimento Negro, ainda indagam sobre a atual postura da Igreja com a população negra e a questão racial, interrogam se é possível lutar a favor da negritude sendo cristão, com base nas dissertações e depoimentos de Jurandyr Azevedo Araujo (2010) ${ }^{11}$.

A partir dessa indagação apresentada por alguns membros do Movimento Negro, os integrantes dos APNs da comunidade Católica, começaram a organizar o grupo de maneira a unir questão como política e o negro; com o intuito de agregar esses dois instrumentos na luta contra a discriminação racial, folclorização e marginalização da cultural afro, conforme relatado por José Geraldo da Rocha (1998).

Os APNs tiveram três anos de mobilização e ações sociais tendo o negro como destaque. Em 1986 eles alcançaram o reconhecimento dentro da Igreja Católica junto com o movimento negro e reivindicaram que a Campanha da Fraternidade (CF) da Igreja Católica fosse relacionada ao negro. Os APN alegaram também que o momento certo seria o ano de 1988, ano em que completaria o centenário da Abolição da Escravatura, pois seria uma maneira de mostrar que a Igreja era sensível aos impactos que o negro sofria.

Esse pedido dos APNs para que a Igreja Católica fizesse a CF de 1988 dedicada ao negro, vai além da questão de lembrar a Abolição. Essa solicitação teve o intuito de demonstrar que a Igreja estava receptiva e atenta às demandas dos negros, o que poderia ser visto como um novo posicionamento da Igreja Católica. Os APNs eram tidos como um Movimento Negro dentro da Igreja e eles não faziam questão de serem vistos como uma entidade institucionalizada.

\footnotetext{
${ }^{11}$ Afirmação baseada na entrevista realizada pela pesquisadora com o Pe. Jurandyr Azevedo Araujo e materiais gentilmente cedidos pelo entrevistado
} 
E então, a CNBB atendeu ao pedido dos APNs e foi de acordo com o tema para a Campanha da Fraternidade de 1988 que falou sobre o negro. A CF tinha como título "Fraternidade e o Negro". O lema - "Ouvi o clamor deste povo" - foi o maior desafio da campanha, pois os membros dos APNs, não se sentiram contemplados.

Porém, a CNBB visava através desse lema, atender ao chamado do negro contra toda a discriminação, desigualdade e falta de oportunidade dentro da sociedade vigente, os tornando parte da Igreja também, na tentativa de apagar o papel conivente que ela teve ao longo da escravidão.

Segundo José Geraldo da Rocha (1998), a Campanha da Fraternidade de 1988 foi bem-sucedida. Mesmo com todas as ressalvas, discussões e divergências, por tratar de um tema jamais abordado dentro da Igreja Católica, a CF obteve sucesso. E através desse feito, a lgreja iniciou uma reflexão sobre a situação do negro, que historicamente demonstrou resistência a todos os desafios impostos pela sociedade.

\section{3}

\section{Ouvi o Clamor Deste Povo, Campanha da Fraternidade que deu voz ao negro cristão na Igreja Católica}

A Campanha da Fraternidade de 1988 "Ouvi o clamor deste povo", que teve como tema "A fraternidade e o Negro" é considerado um dos marcos histórico da Igreja Católica que antecedeu e inspirou a criação da Pastoral Afrobrasileira. Portanto, discorrer sobre CF de 88 e a sua intenção de evidenciar as demandas advindas da população negra torna-se importante para a contextualização da gênese e da articulação das ações que a PAB desenvolve e que são tidas como concretas.

Desde 1961 todos os anos, a Igreja Católica realiza a Campanha da Fraternidade, porém, só após o Concílio Vaticano II, precisamente no ano de 1973 que a CF tem o propósito de denunciar as causas dos males sociais, que contribui para que a vida seja menos humana. As Campanhas evidenciam a preocupação da Igreja sobre as injustiças sociais, através da sua missão profética e de ações concretas, essa afirmativa vai de acordo com as considerações encontradas no texto base (manual) da Campanha da 
Fraternidade de 1988, que ressalta também, que a CF é o gesto concreto do cristão.

"O manual é o principal subsídio para realização de uma $\mathrm{CF}$, nele contém a justificativa pastoral e a teológica, as linhas de ações, os textos bíblicos de referência, os cantos, orações, roteiro para celebrações e artigos relacionados com o tema. Uma análise do manual é boa para entender a abordagem dada pela Igreja". (Oliveira, 2011, p. 64)

O Concílio Vaticano II propiciou a divisão de dois momentos em relação aos temas Campanha da Fraternidade da Igreja Católica. O primeiro momento foi entre 1964-1972, que tinha influência das reformas conduzidas pelo Concílio Vaticano e já o segundo momento, que iniciou no ano de 1973 e se perpetua até o presente momento, reflete o papel que a Igreja desenvolve na sociedade. As atuais CF argumentam sobre as diversas expressões da questão social, não deslindando apenas sobre as questões referentes às doutrinas da Igreja, conforme apontado por Rosenilton Oliveira (2011).

A imersão da Campanha da Fraternidade para dialogar sobre questões referentes às degradações e transformações sociais, faz com que haja uma maior exigência relativa a uma atitude concreta da Igreja Católica e dos cristãos. Requerendo dos religiosos, uma maior assistência ao ser humano que é submetido a essas transformações e desajustes sociais, que muitas das vezes expõe uma extensa camada da sociedade a desigualdade extrema.

E decorrente dessa nova percepção da Igreja Católica, ou seja, da conexão com os problemas sociais, através da Campanha da Fraternidade de 88, as demandas que assolam a população negra tiveram espaço dentro da Igreja. Mesmo tendo enfrentado grande resistência e divergência em relação à escolha do tema, a comemoração dos 100 anos da Abolição da Escravatura, foi brindada pela Campanha da Fraternidade de 1988, com o tema "Ouvi o Clamor deste povo".

"É interessante ressaltar que a CF coloca em evidência, no manual, a luta do povo negro por melhorias sociais, fala sobre o preconceito, a discriminação e a negação de sua identidade e cultura. Quando se refere à religiosidade, afirma ser o povo negro profundamente religioso: "em quase toda casa, há altarzinho, em lugar reservado com imagens, entre as quais a de Nossa Senhora do Rosário e a do Preto velho" - segue a explicação "(...) Nossa Senhora é a grande mãe. O Preto Velho tematiza os antepassados e a mãe - África"'” (CNBB, 1988, p. 53)

Todos os anos a Campanha da Fraternidade desenvolve um manual para subsidiar e nortear as ações sobre a temática escolhida, denominado de texto base. O manual contém textos bíblicos referentes a temática da campanha, assim como a justificativa teológica e pastoral, além de dispor de artigos, 
orações e cantos relacionados ao tema abordado. $O$ texto base segue a metodologia utilizada pelas Pastorais Sociais, que é do ver-julgar-agir, convidando os cristãos a ouvirem a aclamação da população negra, com o objetivo de obter mais paz, justiça e liberdade, de acordo com o apontamento de Rosangela Borges (2001).

O texto base da Campanha da Fraternidade de 1988 "Ouvi o Clamor Deste Povo", chama a atenção dos cristãos para temas relacionados ao negro que até então não havia sido debatido dentro da Igreja Católica. E apenas na 25르 CF que houve um diálogo entre a Igreja e a comunidade paroquial, assim como, com os "homens e mulheres de boa vontade", abordando temas como:

- O negro no Brasil.

- A situação do negro no Brasil hoje.

- O negro hoje e as heranças históricas da escravidão.

- A Igreja e a escravidão.

- A Igreja e as vítimas da escravidão.

O texto base sinaliza o papel que a Igreja Católica teve no período da escravidão. Ele aborda que durante o período Imperial a Igreja apoiou a escravidão, sendo uma das aliadas que fortificaram a imagem inferiorizada do negro. Com a influência política que a Igreja tinha naquela época e tem até os dias atuais, tornou sua participação fundamental para o processo da escravidão, até mesmo pelo fato dessa instituição ter os negros como seres sem alma, por eles não conhecerem o Cristianismo, proferindo que o tráfico de negros ajudaria nesse processo de evangelização.

"O documento de 8 DE DEZEMBRO DE 1975, EXORTAÇÃO APOSTÓLICA

"EVANGELLI NUNTIANDI" do PAPA PAULO VI, especialmente no número 20 continua sendo o grande desafio que ainda não foi abraçado pela Comunidade pregar o Evangelho a todas as culturas, a partir dos valores de cada cultura, mantendo o cerne do vigor evangélico." (Raimundo, 2014, p. 01)

Porém, apenas no ano de 1988 a Igreja Católica que não tratava a situação do negro com a devida atenção libertadora, segundo o texto base da CF de 88, optou por influência dos negros militantes cristãos, dialogar sobre a questão racial. Atentando para o fato de que essa demanda ainda é vigente dentro da sociedade e não foi minimamente sanada, pois, ainda presenciamos diariamente diversas situações de discriminação racial. Prática essa que é contrária à dignidade do homem e que desconsidera enfaticamente a justiça e fraternidade, conforme prega a Igreja Católica em todas as suas ações evangelizadoras. 
O texto base da Campanha da Fraternidade de 88 abordou diversos temas, que sinalizavam a extrema situação de desigualdade que o negro vive socialmente. Esse texto retratou tópicos como o percentual populacional no Brasil, com base em pesquisas do IBGE, que a população negra é superior à população branca. Apontou também sobre o trabalho escravo e a discrepante diferença salarial entre negros e brancos.

A importância da família também foi abordada no texto base da CF de 88 . O manual ressalta sobre a degradação dos laços familiares que os negros escravizados foram expostos durante o período da escravidão. Visto que, essa situação não está muito discrepante atualmente, pois, presenciam-se muitas famílias negras com laços corrompidos, o que acaba contribuindo para que a conscientização da identidade negra perca mais um aliado, conforme ressalta a Nilma Lino (2011), que considera a família um pertinente instrumento de militância negra.

A questão da religiosidade do negro também foi um tema evidenciado no manual da CF de 88, atentando sobre as religiões de Matriz Africana. O texto base sinalizou o quão importante era para os negros escravizados o papel dos chefes dessas religiões, que procuravam aglutinar os negros em condição de escravos, para transmitir os rituais e crenças religiosas através da fundamentação e celebrações clandestinas, já que eram proibidos até de expor sua religiosidade.

\footnotetext{
É interessante ressaltar que a CF coloca em evidência, no manual, a luta do povo negro por melhorias sociais, fala sobre o preconceito, a discriminação e a negação de sua identidade e cultura. Quando se refere à religiosidade, afirma ser o povo negro profundamente religioso: "em quase toda a casa, há altarzinho, em lugar reservado com imagens, entre as quais a de Nossa Senhora do Rosário e a do Preto Velho" - segue a explicação - "(...) Nossa Senhora é a grande mãe. O Preto Velho tematiza os antepassados e a mãe - África" (CNBB, 1988, 53). (Oliveira, 2011, p.65)
}

As considerações referentes ao papel da Igreja Católica no período da escravidão, também foram ressaltadas no texto base, conforme já fora mencionado. O manual sinalizou que a Igreja tem consciência de que muitos cristãos pareciam não enxergar a condição de desigualdade que os negros estavam expostos. Reconheceu também que alguns dos líderes religiosos que tentaram intervir nessa extrema desigualdade racial no âmbito social e da Igreja Católica, foram impedidos de expor sua indignação e sua postura contrária a escravidão.

Contrariando a lógica comum da época, algumas vozes isoladas ousaram condenar a escravidão dos negros. Na América Espanhola, destaca-se o 
capuchinho Frei Francisco José de jaca e Aragão, que escreveu um livro em que, depois de elencar as razões alegadas para justificar a escravidão, as destrói uma a uma ${ }^{6}$. (Texto base da Campanha da Fraternidade de 1988)

O fato da Campanha da Fraternidade de 88 ter sido um marco histórico importante para o surgimento da Pastoral Afro-brasileira, não a isentou de ter enfrentado dificuldade. Pois, a CF não obteve êxito em todos os Estados do Brasil, como por exemplo no Rio de Janeiro, que foi o maior exemplo dessa falta de não aceitação do diálogo racial dentro da Igreja, o que fez com que o Estado desse uma nova roupagem para a campanha.

O bispo do Rio de Janeiro, dom Eugênio Sales, não aceitou as diretrizes propostas pela CNBB e, pela primeira vez, uma diocese realiza uma campanha com tema diferente do nacional. Padre José Enes de Jesus que "foi um momento difícil porque alguns bispos não aceitavam que falasse de negro na Igreja, então muita coisa foi cortada, a gente foi costurando acordos". (Oliveira, 2011, p. 63)

A dificuldade que a diocese do $\mathrm{RJ}$ teve para aceitar em falar sobre a questão racial, fez com que transparecesse que havia dois interesses na CF de 88. Que era a vontade dos membros dos APNs em expor a situação social e política de desigualdade que o negro estava exposto e a da Igreja Católica de amenizar essas questões no seio da Igreja. Com isso, o Estado do RJ escolheu como lema para sua Campanha da Fraternidade de 88 "Várias raças um só corpo".

Mesmo com essa situação, um dos maiores propósitos da Campanha da Fraternidade de 88 foi o reconhecimento da Igreja Católica de um pecado histórico, o que presume um pedido de perdão aos negros. Pois, sabe-se que a Igreja não denunciou a prática da escravidão e se colocou conivente através do seu consentimento com período escravocrata. Com isso, a instituição Igreja visa colaborar com ações em prol do social, através dessas campanhas, corroborando para a construção de uma sociedade mais justa, segundo o texto base da CF de 88.

Supõe-se então, que as ações concretas que a Igreja Católica realiza através da Campanha da Fraternidade, conforme a referida CF de 1988, visa além de um pedido de perdão a população negra, almeja também a superação do racismo dentro da Igreja, que mesmo sendo velado, ainda faz parte da instituição. Assim como, trabalhar a questão da identidade do negro, através da promoção de grupos que façam diálogos sobre a temática racial, promover Agentes de Pastoral Negros e interagir com religiões que prezam pela cultura da população negra. 
Culminou, portanto, da Campanha da Fraternidade de 88 a responsabilidade da Igreja Católica em intervir através de ações de caráter social, colaborando para uma sociedade mais fraterna e livre de injustiças. O texto base da Campanha, lista algumas pistas para que se alcance esse objetivo, citando ações como: a caridade em ação, rever a linguagem e atitudes preconceituosas, releitura da história da população negra e a solidariedade com os negros de outros países.

Mesmo que a Igreja Católica através da Pastoral Afro-brasileira transpareça que há "facilidade" em conciliar militância negra e evangelização, os relatos de membros da PAB apontam grande dificuldade de evangelização e conscientização dos cristãos dentro da Igreja, mesma após a CF de 88.

Por todas as considerações referentes à Campanha da Fraternidade de 88 expostas na pesquisa, entende-se que dissertar sobre as considerações advindas do seu propósito são pertinentes para o diálogo em relação a atuação da Pastoral Afro-brasileira. E mesmo que não tenha ocorrido à supressão total do racismo dentro da Igreja Católica, considera-se uma conquista falar sobre questão racial dentro de uma instituição totalmente eurocêntrica, porém, compreende-se também que ainda há muito para avançar sobre essa questão dentro da Igreja Católica.

\author{
ORAÇÃO DA CAMPANHA DA FRATERNIDADE - 88 \\ Deus de nossos pais, Senhor da História, Pais dos pobres! \\ Tu que ouviste o clamor de teu povo Israel e o libertaste da terra da \\ servidão,
}

Arranca de nosso coração, da tua lgreja e de nossa sociedade, as marcas do pecado da escravidão, que dominou o Brasil, por tantos séculos! Livra-nos do racismo, do preconceito e da discriminação! Ouve o clamor do povo negro, com todos os empobrecidos da Terra, a caminho da Libertação!

Faze reinar entre nós tua justiça "derruba do trono os poderosos e exalta os humildes, sacia de bens famintos e despede os ricos sem nada". Senhor, apressa o dia, em que vivendo o teu Amor, sejamos, no coração da história, semente do Povo Novo, livre de toda injustiça e de todo pecado.

Isso te pedimos com a Virgem Aparecida, por Jesus Cristo, na unidade do Espírito Santo! 
Amém

\section{4}

\section{A Pastoral Afro-brasileira e sua reflexão social}

Através da Campanha da Fraternidade de 1988, a Igreja Católica visava chamar a atenção para as demandas em que os negros estavam expostos socialmente, assim como, agir nas suas vulnerabilidades, como a desigualdade racial, racismo, preconceito e discriminação. Com o intuito de contribuir para o melhor entendimento do cristão leigo sobre a questão racial e a identidade do negro, através das ações concretas realizadas pela Pastoral Afro-brasileira, por meio da sua reflexão social.

A reflexão social da Pastoral Afro-brasileira consiste em realizar atividades que buscam conscientizar o negro sobre sua negritude, sua ancestralidade e sua riqueza cultural. A CNBB aponta em seus estudos sobre a Pastoral Afrobrasileira, a importância de contribuir para a superação dos obstáculos que impede a população negra de viver em situação digna. Assumindo o compromisso de revelar que a Igreja Católica nas diferentes regiões do Brasil, compreende seu papel diante da situação de desigualdade que vive o negro.

O trabalho da Pastoral Afro-brasileira em diversos Estados e regiões consistem em animar grupos em comunidades, seja eclesial ou não. Pois, em muitos Estados a PAB se organiza para participar de movimentações sociais, que evidenciam as demandas dos grupos ditos como "excluídos". Com o intuito de colaborar com esses movimentos e fortalecer sua militância. Visto também, que diversos movimentos sociais, militam pela igualdade racial, a fim de que a população negra descubra e valorize sua origem tradicional africana dentro do Brasil, assim como, ser solidário a difícil realidade dos negros e excluídos.

Porém, não há como dissociar totalmente a fé do trabalho social desenvolvido pela Pastoral Afro-brasileira, até mesmo por ser um grupo de origem religiosa e essa não é a intenção dos membros articuladores e tão pouco dos líderes religiosos envolvidos com a PAB. Pelo contrário, o propósito da Pastoral é confrontar a fé com as injustiças, fruto das desigualdades advindas do sistema capitalistas, conforme analisa o assessor nacional da PAB, Jurandyr (2016).

"A atuação junto aos afro-brasileiros concretiza o compromisso da Igreja assumido nas comemorações dos 500 Anos de evangelização do Brasil, quando manifestou a obrigação de se empenhar na defesa das diferenças culturais, com especial 
atenção para com as populações afro-brasileiras e indígenas". (CNBB, 2000, p. 59)

É importante esclarecer que o trabalho social da Pastoral Afro-brasileira tem o propósito de se tornar visíveis nos cenários em que os negros estão presentes, com o intuito de serem notados pela população e para que ocorra também, o fortalecimento da atuação e da conscientização sobre a questão racial. Sem esquecer de salientar, para que esse feito ocorra, a PAB precisa dispor de incentivo, compromisso e participação dos líderes religiosos, da comunidade e principalmente dos agentes pastorais.

O compromisso com os mais pobres, assim como a valorização das experiências apresentadas pelas comunidades, compõe a reflexão social da Pastoral Afro-brasileira, conquistando um espaço de fala no âmbito social, que permite evidenciar sinais que revelam a espiritualidade da PAB. Esses sinais que entrelaçam a espiritualidade com a luta social são evidenciados através de direcionamentos que a Igreja Católica aponta como uma postura cristã, que é o acolhimento e prática solidária aos desprezados e pequenos socialmente falando.

A conquista pelo novo é um dos papéis da Pastoral Afro-brasileira, pois Jurandyr Azevedo (2016) informa que a conservação do que já foi conquistado, não vai corroborar para a conquista de um novo caminho. A questão principal da $P A B$ é galgar novas estratégias para contemplar a luta em prol dos direitos e a favor da igualdade racial, priorizando as demandas evidenciadas pelas comunidades negras.

"É uma necessidade pautada na estratégia sócio-política-transformadora. Como fruto deste trabalho de alinhamento e fortalecimento do diálogo, foi programado para 2017, um novo formato para reformar sua estratégia e seus instrumentos de modo a priorizar trabalho dos grupos organizados ou que estão em fase de organização". (Araújo, 2016, p.01)

A preocupação da Pastoral Afro-brasileira com a questão social, em atuar nas expressões que propiciam as desigualdades que assolam a população negra até os dias atuais, fez com que fosse criado o Congresso Nacional das Entidades Negras Católicas (CONENC). O Congresso é um encontro de formação de lideranças negras, que visa o estudo de subsídios relacionados com alguma temática pertinente a população negra e também se dispõe a ensinar os líderes/agentes técnicos para ser colocada em prática nas suas dioceses, paróquias e comunidades. 
As entidades negras observaram a necessidade de buscar novos caminhos para a evangelização, com isso, em 1998 foi criado o CONENC, a fim de respeitar toda a cultura e tradições afro-brasileiras, assim como a identidade do negro. Com o propósito também de revelar a vitalidade e a sintonia que existe entre os seguimentos representativos que envolvem as Comunidades Negras. Os primeiros encontros aconteciam de dois em dois anos e após o ano de 2009, começou a ser realizado a cada três anos.

A responsabilidade social que a Pastoral Afro-brasileira desenvolve, também transparece através das considerações advindas dos encontros do CONENC. O Congresso contribui ao pensar ações afirmativas que colaborassem na conjuntura sócio-econômica-cultural, inclusive para a questão política do Brasil que estigmatiza, exclui e discrimina a população negra. A formação e o desenvolvimento dos cristãos que integram as comunidades negras também é a prioridade do CONENC, pois, busca intensificar o processo de conhecimento e aceitação das expressões da cultura afro-brasileira.

"Esse Encontro Nacional tem como finalidade discutir, refletir, apresentar propostas e compromisso para novas estratégias de atuação em cada entidade, buscando um relacionamento cooperativo e ético que conduza a novas atitudes de parceria e de construção coletiva". (CONENC, 2012, p.05)

A cada ano que é realizado o CONENC é abordado um tema referente a uma expressão da questão sociale assim como a Campanha da Fraternidade, é redigido um manual que serve de subsídio para o Congresso, a fim de pautar o debate $\mathrm{e}$ as atividades do encontro. O no manual do VII CONENC, que aconteceu no município de Duque de Caxias, no ano de 2015, encontra-se a preocupação direta com o negro, referente às demandas emergidas desde o período da escravidão, evidenciando a situação de pobreza que grande parte da população negra está exposta, decorrente da conjuntura de preconceito, discriminação e racismo que os negros se encontram.

O manual também atenta para a militância dos negros que são expostos a situação discriminatórias dentro da sociedade civil, visando pressionar o Estado para alcançar seus direitos, através de Políticas Afirmativas. Salientando também o desígnio de refletir sobre a missão dos Agentes de Pastoral do futuro, que estão envolvidos com a caminhada da Pastoral Afro-brasileira, com o propósito de fazer com que cada agente compreenda a dinâmica do outro.

"A Pastoral Afro-brasileira tem procurado fazer subsídios de formação e a cada Congresso Nacional, que se realiza hoje a cada três anos, nós fazemos um subsídio com temas próprios para a ocasião. Uma diocese se encarrega para organizar cada congresso. Durante dois anos preparamos todo o material e toda a Organização". (Araújo, 2017) 
Para o Congresso, os grupos realizam estudos em suas regiões, para discutir sobre o tema do encontro, munidos do manual para dialogar com enfoque nas questões emanadas do subsídio, que serão expostas no encontro. $\mathrm{Na}$ verdade, o CONENC da continuidade ao trabalho que foi iniciado em cada região, trabalhando e dialogando com base nos questionamentos que foram expostos nesses grupos, com o propósito de intensificar o comprometimento com a ação evangelizadora e fortalecer a responsabilidade social com os negros.

"Queremos assumir o desafio de intensificar a ação comprometida com os negros e negras que permanecem a margem da sociedade, em situação de vulnerabilidade social. São vidas ameaçadas enquanto vidas e na dignidade do seu desenvolvimento. A pertença eclesial é fato de animação e compromisso com o outro, sobretudo o mais fragilizado". (CONENC, 2015, p. 10)

Alguns dos objetivos do CONENC são promover um maior entrosamento entre os integrantes da Pastoral Afro-brasileira, proporcionar a troca de experiências, dialogar, estudar e pensar propostas para melhor promoção e assistência do negro. Além de pensar sobre uma teologia afro e aumentar o estudo sobre ações afirmativas, com a finalidade de propor mais Políticas Públicas que favoreçam a população afro-brasileira.

Conclui-se, portanto, que o propósito do Congresso Nacional das Entidades Negras Católicas é contribuir para a melhor articulação das ações tidas como concretas que a Pastoral Afro-brasileira desenvolve nas diversas regiões do Brasil, através da formação dos Agentes Pastorais presente. Para que os mesmos regressem para suas comunidades, dioceses e paróquias, mais fortalecidos pela fé, consciente da responsabilidade social da PAB e permeados pela tradição afro-brasileira que enriquece a cultural do Brasil.

Conforme aponta o manual da Campanha da Fraternidade de 88, o Brasil foi o último país que pôs fim na prática da escravidão, o que não significou o rompimento da exploração e da situação de subalternidade dos negros, pois, o Estado não consumou políticas que desse apoio à população negra, após esse doloroso e discriminatório período da escravidão. E esse questionamento faz parte dos debates da Pastoral Afro-brasileira, salientando ainda mais a responsabilidade e reflexão social que a PAB desenvolve em suas ações em prol da igualdade racial, visando agir na profunda desigualdade que os negros sofrem em relação à população branca.

$\mathrm{Na}$ educação, por exemplo, o índice de analfabetismo na população negra era, praticamente, o dobro, em relação à população branca. Na área econômica, os 
negros tinham menos oportunidades de emprego. Se estavam empregados, a renda média era inferior à dos brancos. (CNBB, 1988, p.16)

Outra ação que evidencia a responsabilidade social da Pastoral Afrobrasileira é o Conselho Epsiscopal Latino-Americano (CELAM) ${ }^{12}$ da Igreja Católica. No ano de 2002, o CELAM chamou atenção para as demandas dos negros e reuniu no Quito, os Bispos comprometidos com a Pastoral Afroamericana, que envolve a Pastoral Afro da América Latina e Caribe. Esse encontro tinha o propósito de interagir e compartilhar as experiências das Pastorais, para que assim pudessem assumir as perspectivas dos grupos existentes.

Assim como todos os encontros relacionados à Pastoral Afro a preocupação concomitante com a evangelização, sempre é a reflexão social, ou seja, qual a posição e as mazelas sofridas pela população negra. E assim, ocorreu no encontro do CELAM em 2002, que discutiu sobre as demandas relacionadas a questão racial, como a "Exclusão-pobreza do Povo Negro", ressaltando também o papel de resistência que o negro desenvolve na sociedade, por ser exposto a diversas situações de desigualdades.

O encontro também evidenciou a opção da Igreja Católica pelos pobres, a preocupação de seguir a linha da fraternidade, assim como, assumir o compromisso pela evangelização inculturada, que se faz presente nas ações concretas da Pastoral Afro. Os Bispos que participaram, também sinalizaram o papel que a Igreja assume de defensora dos direitos humanos, em prol de uma sociedade mais justa, fraterna e igual, a fim de incidir de forma direta nas transformações sociais.

Tanto o CONENC, quanto o CELAM, têm as mesmas características, que é a articulação da reflexão das demandas expostas pela população negra. Esse ato favorece a luta em prol da igualdade racial que a Pastoral Afro se debruça em seu exercício. A reflexão é a base para dialogar sobre o pilar social, que pauta a articulação das Pastorais de todos os Continentes e do Caribe.

A interação da Pastoral Afro-brasileira com agentes de outros movimentos sociais, principalmente o Movimento Negro, faz com que transpareça a responsabilidade social que a $\mathrm{PAB}$ desenvolve. Embora, cada agente tenha sua

\footnotetext{
${ }^{12}$ CELAM é um organismo da Igreja Católica fundado em 1955 pelo Papa Pio XII a pedido dos bispos da América Latina e do Caribe.
} 
peculiaridade de pensamento e atuação, o fortalecimento da igualdade racial, que é o produto final da militância dos movimentos que visam à questão racial, assim como a Pastoral Afro, será beneficiado e vai tornar a luta em questão mais visível.

Conclui-se que o grande objetivo da ação articuladora da Pastoral Afrobrasileira é tornar perceptível a necessidade de dialogar e efetivar ações que vissem a igualdade racial, através da sua ação evangelizadora e da sua responsabilidade social. Pois, através das considerações de kabengele Munanga (2006), que ressalva o compromisso do Movimento Negro, que tem a finalidade de conscientizar o negro de que a sociedade vive uma discriminação racial camuflada, que afeta diretamente a vida da população negra.

Essa finalidade do Movimento Negro e de todos os outros Movimentos Sociais, que militam em prol da igualdade racial, aqui mencionados, vão de encontro ao propósito da Pastoral Afro-brasileira. Pois, mesmo que a PAB seja um movimento de maior protagonismo dentro da Igreja Católica, ela soma a ação evangelizadora com a sua responsabilidade social, através das reflexões e contextualizações das demandas da questão social.

\section{5}

\section{O pilar de atuação da Pastoral Afro-brasileira}

Evidenciar que a Pastoral Afro-brasileira dispõe de uma sobre a reflexão social, provém da importância de discorrer sobre preconceito racial, discriminação e racismo, que compõem o pilar de atuação da Pastoral. E para que esse diálogo flua de forma coerente, é necessário deslindar sobre identidade negra, que não é algo tão simples.

Para Nilma Lino (2012), ainda não há de fato uma resposta tida como satisfatória, para a indagação do que é identidade. E mesmo que ainda não tenha essa explicação, a identidade pode ser vista como uma construção social, que envolve a história e a cultura de um grupo étnico/racial.

De acordo com Silvia Novaes (1993), citada por Nilma Lino (2012), a identidade é a criação do ser coletivo. Cada grupo tem sua caracterização específica, que é essencial para enfrentar os desafios da modernidade, como por exemplo, a população negra, que sofre com ações negativas como o 
racismo, a discriminação e preconceito racial, denominado como problema social:

(...) Qualquer grupo humano, através do seu sistema axiológico sempre selecionou alguns aspectos pertinentes de sua cultura para definir-se em contraposição ao alheio. A definição de si (autodefinição) e a definição dos outros (identidade atribuída) têm funções conhecidas: a defesa da unidade do grupo, a proteção do território contra inimigos externos, as manipulações ideológicas por interesses econômicos, políticos, psicológicos, etc. (Munanga, 1994, p. 177-178)

A identidade é individual de cada grupo, o que os tornam diferentes socialmente, emergindo a cultura e costumes específicos nas relações sociais, permitindo afirmar que a identidade é uma construção social. Tratando especificamente da questão racial, deve-se ressaltar que há um padrão social seguido e determinado, que discrimina e muita das vezes exclui o que é diferente do tido como "correto", mesmo sabendo que as diferenças também não são hereditárias. O autor Philiph Gleason (1980), relata através de seus estudos sobre identidade:

(...) necessita de uma sensibilidade às complexidades intrínsecas ao assunto e maior atenção à demanda de precisão e consistência na sua aplicação. Porém, a enorme popularização do termo tem resultado em um efeito o oposto, tornando o termo identidade cada vez mais difuso e próximo de um clichê, encorajado, assim, um crescente uso mais relaxado e irresponsável do mesmo.

A identidade vai além de ressaltar os costumes de um grupo, ela visa evidenciar também a música, religião, a alimentação, as referências tradicionais que marcam cada civilização. Porém, não é fácil compreender que cada "povo" tem características próprias e no caso da população negra até hoje esses costumes são menosprezados, por conta da estigmatização carregada desde o período da escravidão. Essa situação causa grave danos no cotidiano do negro, que sofre com o preterimento na vida profissional, social e até mesmo amorosa. (Nilma Lino,2012)

Essa estigmatização que o negro sofre socialmente influi diretamente na formação da identidade da população negra, visto que, a identidade é uma construção social. E a estereotipação desse "povo", faz com que os negros tenham de si, uma visão inferiorizada e seu auto-conceito não seja positivo. llustrando assim, a forma com que o preconceito racial, a discriminação racial e o racismo, atuam em suas vidas, colaborando para que a população negra desconsidere suas potencialidades e sua riqueza cultural.

A violência racista ainda hoje exerce um poder de destruir a identidade do indivíduo negro. Esta identidade é negada através de falsos valores, que a comunidade negra é obrigada a absolver. As imagens distorcidas do povo negro, divulgadas nos meios de comunicação, nos livros didáticos e em outros veículos 
de comunicação, ou ainda as obrigatoriedades da boa aparência vão criando distâncias entre a pessoa e sua própria identidade. (Cabral, 2007, p. 15)

Dissertar sobre a identidade negra é bastante complexo, por envolver questões pessoais, sociais e raciais. Pois, a identidade envolve um sentido de pertencimento do grupo social referente, sinalizando sua cultura e principalmente sua história. A formação da identidade negra é gradativa, principalmente por envolver diversas variáveis, que colaboram na construção da sua identidade. (Nilma Lino, 2012)

Stuar Hall (1995) tem uma grande significância no debate sobre identidade, ele discorre que a construção social é o pilar da identidade, pois ela é advinda de práticas sociais que estão em grande processo de vicissitudes. O que faz com que cada "povo" tenha suas próprias características, pois cada período de mudança é refletido de forma diferente em determinado grupo.

Com base na construção da sociedade moderna, entende-se que a identidade não é unificada. Pelo contrário, a identidade se encontra de forma fraturada e fragmentada, por se tratar de uma construção social. Pois, se tem em vista que a identidade não é apenas uma expressão cultural, contrariamente, ela permeia os aspectos políticos, sociais e históricos, conforme sinaliza a afirmativa “(...) um eu coletivo capaz de estabilizar, fixar ou garantir o pertencimento cultural ou uma "unidade" imutável que se sobrepõe a todas as outras diferenças - supostamente superficiais". (Stuart Haal, 1995, p. 108).

A identidade é tida como ponto de apego temporário às posições-desujeito que as práticas discursivas constroem para nós, ou seja, a identidade é o ponto de encontro entre o discurso e a prática, tornando cada grupo particular em seu discurso, em suas práticas, em seus costumes. Na maioria das vezes, essa identidade é fruto de alguma falta interceptada por uma divisão e que não podem ser parecidas.

A complexidade em discorrer sobre identidade é refletida através da resistência que o grupo dominante tem em respeitar e entender a especificidade de cada "povo", entendendo sua cultura, costumes e hábitos como absolutos. Essa dominação desconsidera a formação da identidade de outros grupos, que é construída através da particularidade da história, da sua vivência e até mesmo dos traumas de cada um, como é no caso da população negra.

O debate em torno da identidade é um dos pilares para dialogar sobre identidade negra. Para Nilma Lino (2012), nenhuma identidade é construída no isolamento, ela é construída através da história, do diálogo e ao longo da vida, 
portanto com a identidade negra não poderia ser diferente. A história é indispensável para formação da identidade do negro, que foi construída gradativamente, principalmente por sua trajetória ter sido fruto de uma prática de exploração da população negra.

Essa prática deixou marcas na história do negro e hoje os torna um grupo que simboliza resistência dentro da sociedade. $O$ negro carrega socialmente 0 sinônimo de algo negativo e essa análise pode ser comprovada através de constantes relatos de pessoas negras sendo alvo de piadas negativas, dentro de instituições, estabelecimentos, órgãos públicos e principalmente nas redes sociais. São histórias discriminatórias e vexatórias que se referem à cor da pele do negro, aos seus costumes, seus hábitos e até mesmo demonizando sua expressão religiosa (religiões de Matriz Africana).

Esses ataques racistas é o que muitas das vezes aflora a militância em alguns indivíduos, que passam a enxergar a luta em prol da igualdade racial, como um auto-cuidado e ativam o exercício de cuidar do próximo. O religioso Padre Clovis Cabral (2007), discorre sobre essa questão e relata essa tomada de consciência, resistindo ao que lhe é imposto socialmente e assumindo seus hábitos, costumes, usar seu cabelo e se vestir conforme seu próprio gosto. $\mathrm{O}$ que passa a fortalecer a identidade do negro na sociedade.

A superação do que é imposto historicamente pela sociedade referente ao negro é necessário, mesmo que a construção da identidade negra seja fruto de uma prática de exploração, da relação com o outro, tratando o negro como um ser impregnado de fracassos, derrotas, que não possui beleza e inteligência. $E$ a partir desse olhar social, que se encontra a necessidade de movimentos e organizações em intervir contra o racismo, com o propósito de fortalecer a identidade negra.

Tendo em vista que a identidade é proveniente da construção social, tornase indispensável salientar que a escravidão teve um grande papel na formação da identidade negra, pois de acordo com Stuart Hall (1995), o passado histórico é percebível nas identidades. Assim, acontece com a construção da identidade negra, mesmo tendo em vista que a escravidão foi um momento de prática de exploração do negro, há atualmente reflexos do período escravagista na identidade desse "povo", que é demarcado historicamente por estigmatizações e discriminações.

Cabe também compreender que a identidade não é apenas a diferenciação da cor da pele e sim o fruto de um processo histórico, conforme já 
fora mencionado, que rende até os tempos atuais o menosprezo das demandas da população negra, que são advindas do período da escravidão. Desta forma Kabengele Munanga (2015) alerta para o fato de que a construção da identidade do negro perpassou pelas relações mercantilistas, tráfico negreiro, existente no período da escravidão, assim como a colonização, processos que não foi vivido por brancos, o que exemplifica a importância da história na construção da identidade.

Desde o período da escravidão que o negro é menosprezado perante a sociedade. E essa prática de discriminação não é exclusividade do Brasil, pelo contrário, essa visão estereotipada que o negro dispõe é uma concepção mundial. Porém, cabe sinalizar que a cultura negra muito influi nos hábitos da sociedade brasileira, conforme relata o próprio manual da campanha da Fraternidade de 88 da Igreja Católica. Esse mesmo manual discorre sobre a importância da identidade negra para a formação do Brasil, identificando sua influência na culinária, literatura, religião, música, dança e até mesmo na economia, através do seu trabalho explorado no período da escravidão.

"É nesse contexto histórico que devemos entender a chamada
identidade negra no Brasil, num país onde quase não se houve
um discurso ideológico articulado sobre a identidade "amarela"
e a identidade "branca", justamente porque os que
coletivamente são portadores das cores da pele branca e
amarela não passaram por uma história semelhante à dos
brasileiros coletivamente portadores da pigmentação".
(Munanga, 2015, p.01)

Outro aspecto relevante no campo do debate da identidade é a influência da família, que pode ser vista como base para a formação da identidade do indivíduo. Pois, é a família que ao longo das transformações sociais, vão criando ramificações provenientes das relações estabelecidas com outros grupos e indivíduos, através também da sua conscientização e entendimento da história vivida pela população negra. (Gomes, 2012)

$\mathrm{Na}$ Pastoral Afro-brasileira, geralmente os jovens que participam das atividades, foram impulsionados por seus pais que também são membros da PAB e que tem trajetória de militância e responsabilidade em relação à questão racial. Dificilmente encontram-se jovens atuantes na PAB envolvidos com a militância por outras vias se não a familiar, o que preocupa os membros da Pastoral em relação ao seu futuro, pois poucos jovens encontram-se comprometidos com o ativismo em prol da igualdade racial. 
Conforme sinaliza Paulo Vinícius Baptista (2008), no Brasil, a cor da pele das pessoas e suas características fenotípicas, são utilizadas como uma das formas que classificam o ser humano. E essa classificação racial determina a oportunidade que cada indivíduo terá, pois, a sociedade se apropria de diversas questões para discriminar o negro, seja pela sua história, pela cor da sua pele, pelo seu cabelo, pela sua cultura e religiosidade.

Porém, o debate sobre identidade negra, não se esgota e nem se resume em apenas dissertar sobre sua construção, pelo contrário, o debate permeia toda a questão racial, que está imbricada com a questão da discriminação racial, preconceito racial e principalmente o racismo. Sendo assim, o objeto principal de atuação da Pastoral Afro-brasileira, influenciado também pela estereotipação física que atribuem ao negro, caracterizando seus traços como fora do padrão socialmente aceito. Que é fruto da hierarquização racial, de acordo com Nilma Lino (2013), que foi estabelecida desde o início da relação de exploração entre capitalista e escravo durante o período da escravidão.

“(...)tomada de consciência de um segmento étnico-racial excluído da participação na sociedade, para a qual a contribui economicamente, com trabalho gratuito como escravo, e também culturalmente, em todos os tempos na história do Brasil". ( Munanga, 1994, p.187)

Desta forma considera-se no presente projeto que o preconceito racial, discriminação racial e racismo, formam o conjunto das expressões da questão racial por serem conceitos que caminham juntos. Octavio lanni (2004) ressalta que a questão racial tem uma íntima relação com a questão nacional, por externar o desafio que é integrar o negro em diversos âmbitos, por termos uma sociedade racista e classista. Identificando o racismo como um problema social e não como uma atribulação apenas para o negro.

Ao dissertar sobre as expressões da questão racial, percebe-se o quão importante é a atuação da Pastoral Afro-brasileira contra o racismo e suas ramificações. As ações da PAB tiveram início dentro da Igreja Católica, através de cursos de formação voltados para a temática racial, com presença de lideranças religiosa e leigos, para dialogar e capacitar os membros da Pastoral, com o propósito de dissertar sobre sua história, identidade, sobre "raça" e racismo.

Há autores como Gilberto Freire (1944), que propagam que no Brasil há uma cordialidade racial, ou seja, que há uma democracia racial, porém, não é isso que se presencia diariamente. A sociedade é permeada de racismo, 
discriminação racial e preconceito racial, porém, grande parcela da sociedade não tem conhecimento de que se trata de conceitos diferentes. $E$ essas diferenças serão sinalizadas por alguns autores que discutem a temática da questão racial.

A imagem do Brasil como país onde as relações raciais seriam predominantemente pacíficas foi fundamental para escolher recair sobre o país, que representava a esperança de relações raciais harmônicas. A concepção que motivou os estudos era de um país como "laboratório da civilização" ou uma "democracia étnica" (expressões de Arthur Ramos e Gilberto Freire). (Baptista, 2008, p.74)

O cenário atual é um observatório das questões raciais, pois se percebe que o negro ainda se depara com discriminações, precariedade nas relações de trabalho, na academia e em relacionamentos amorosos, o que evidencia ainda mais o caráter de resistência da população negra. Essas expressões citadas exprimem as mazelas que os negros estão expostos em seu cotidiano, que são frutos do período de exploração que foi a escravidão. Porém, a libertação desses escravizados conforme relata Paulo Vinícius Baptista (2008) não significou que os negros não seriam mais discriminados, pelo contrário, eles continuam expostos à discriminação que é o pilar do racismo e do preconceito racial.

Dentre as expressões da questão racial, que carecem de maior atenção, por expressar bastante sobre cada população, está a cultura, que muitas das vezes enfrentam um caráter discriminatório. Pois, a cultura tem o corpo como objeto de alteração exercida, capaz de ser modelado e modificado socialmente. Criando uma relação com as expressões da questão de gênero, que assim como a discriminação racial, significa diferenciar, discernir, distinguir o outro, como base dessa prática discriminatória. (Nilma Lino, 2013)

A discriminação é um ato de se manifestar preferência por um grupo ou indivíduo, ou seja, um comportamento externado através de atitudes que excluem pessoas que estão na mesma situação ou em situações semelhantes, refletido por Jorge da Silva (2008). Contemplado por Nilma Lino (2012), que relata que a pessoa discriminada é excluída apenas pela cor da sua pele, pelo seu cabelo crespo, que é tido pela sociedade como sinônimo de falta de beleza, levando a questão latente do branqueamento ${ }^{13}$.

\footnotetext{
${ }^{13}$ Branqueamento é tornar o branco como exemplo e padrão de beleza social de acordo com explanações de Nilma Lino (2012).
} 
A discriminação racial é consequência do período da escravidão, que degrada totalmente a relação de igualdade e interação do negro na estrutura social. Carlos Hasenbalg (1979) através de Florestan Fernandes, assinala que nem mesmo após abolição da escravatura os negros escravizados se tornaram livres da situação de preconceito e discriminação que eles sempre foram expostos socialmente.

Tomando-se a rede de relações raciais como se apresenta em nossos dias, poderia parecer que a desigualdade econômica, social e política existente entre "negro" e "branco" fosse fruto do preconceito de cor e da discriminação racial. (Fernandes, 1979, p. 80)

A discriminação também é temática exposta no texto base da Campanha da Fraternidade de 88 , onde exprime que não há realmente oportunidade para todos, reconhecendo que há sim práticas racistas e discriminatórias na sociedade. O texto ressalva que o negro enfrenta discriminação no trabalho, apresentando dados de pesquisas realizadas, que aponta o maior número de brancos do que negros empregados.

O manual da CF de 88, também sinaliza a diferença salarial entre negros e brancos, apontando que há um número mais elevado de negros em "ocupações manuais". Além de ressaltar a questão da chamada "boa aparência", segue o padrão social de beleza, discriminando as características fenotípicas do negro, assim como reconhecendo que a população negra ocupa os lugares mais segregados no âmbito social, corroborando com a conceituação dos autores citados.

A ausência de negros nos graus mais elevados da hierarquia social é flagrante: é praticamente nula, por exemplo, a presença de negros nos primeiros escalões dos diversos níveis do governo e do poder legislativo e judiciário. O mesmo fenômeno se reproduz no topo da hierarquia militar, acadêmica e na carreira diplomática. (Campanha da Fraternidade, 1988, p.39)

Porém, a herança do período escravocrata, rendeu ao negro outra ação negativa, que é o preconceito racial. Antônio Sérgio Guimarães (2004) discorre que o preconceito racial é o obstáculo principal para a interação do negro, pois é um julgamento que o inferioriza. Por tomar propriedade da conceituação do referido autor, denomino o preconceito como ação negativa, por exteriorizar uma atitude não positiva de um determinado grupo ou indivíduo, por ter como referência de padrão social, seu próprio grupo.

O preconceito racial, segundo Jorge Silva (2008) se compreende em ter uma opinião negativa de um grupo ou indivíduo, que normalmente não são claras. Que não se consiste em ter tido experiências negativas, que nutri esse 
sentimento ruim, ressaltando e atentando para o fato de que todos nós podemos ser cometidos por essa ação, pois somos adestrados a ter algum tipo de preconceito.

"É claro que o preconceito afeta as pessoas ou grupos aos quais se dirige, mas não se deve desconsiderar o fato de que ele afeta também as pessoas que o nutrem, independentemente de manifestar-se objetivamente sob a forma de discriminação". (Silva, 2008, p. 31)

O preconceito racial é algo que se aprende na sociedade, quer dizer que ele não é inato. Vide por exemplo às crianças, elas não nascem com preconceitos, os adquirem ao longo da sua vida. Dando como observatório o relato da Senhora $\mathrm{V}^{14}$, integrante da Pastoral Afro-brasileira Achiropita, que relatando que ensinou suas filhas desde infância a terem autoestima e saber da história da população negra, para que ninguém pudesse trata-las com indiferença.

Outro exemplo bastante latente dentro das universidades são os cotistas que sofrem recorrentes preconceitos, advindos de pessoas que tem uma opinião formada antecipadamente sem conhecimento dos fatos e sem saber por qual motivo há as cotas raciais, segundo Bentes (1999), citado por Nilma Lino (2012).

Por isso, faz-se necessário discutirmos a superação do preconceito, juntamente com as formas de superação do racismo e da discriminação racial, pois estes três processos: "se realimentam mutuamente, mas diferem um pouco entre si. O racismo como doutrina da supremacia racial, se apresenta como fonte principal do preconceito racial. (Bentes, 1999, p.21)

As marcas da escravidão se consumam nessas ações negativas, conforme analisa o manual da Campanha da Fraternidade de 88, ressaltando que os sinais do período em que os negros foram escravizados, são encontrados no trabalho denominado como manual. Sinalizando a grande ojeriza que a sociedade de uma maneira geral, tem do trabalho manual, e é exatamente esses trabalhos que agregam grande números de negros, que até hoje passam por situação de exploração nas relações de trabalho, exemplificando, portanto, uma das formas de preconceito racial.

As expressões negativas proferidas socialmente, relacionadas ao negro contribuem para o alargamento do preconceito racial, que é um dos causadores da desigualdade social. Esse também é um alerta que o manual da Campanha

\footnotetext{
${ }^{14}$ Depoimento de entrevista realizada pelo próprio pesquisador, com a Senhora Valéria na Paróquia Nossa Senhora de Achiropita.
} 
da Fraternidade de 88 ressalta, pois, o texto considera que as marcas da escravidão introjetou na sociedade, a visão inferiorizada da população negra. Considerando que a cor da pele negra é uma forma de justificar toda a situação de desigualdade e preconceito exacerbado que o negro sofre socialmente, porém, é velado, principalmente dentro da Igreja Católica, o que justifica a existência de práticas que visem a igualdade de racial.

A discriminação do negro o aliena duplamente, por fora da sociedade de classes e por força do racismo. As reações da população negra permanecem por muito tempo apenas no campo da religião e da arte. As tentativas no campo político sofreram repressão. Exemplo: em 1931, organiza-se a Frente Brasileira Negra que, logo depois, a ditadura de Vargas extingue, em 1937. Nas eleições de 1945, 1975 e 1982 aparecem candidatos aglutinando os interesses da população negra. (Texto base da Campanha da Fraternidade, 1988, p.49)

A diferença entre discriminação e preconceito é algo que precisa ficar claro dentro da sociedade brasileira. Principalmente porque o preconceito vai acompanhar constantemente seu condutor, tendo na maioria das vezes um caráter implícito. Pois, geralmente a pessoa carrega consigo o preconceito, mas, não declara o fato de não gostar de determinado grupo ou indivíduo, por simplesmente ser contra o que eles consideram "diferentes" do seu próprio grupo. (Jorge da Silva, 2008)

Dialogar sobre racismo é um assunto de extrema complexidade, principalmente por se tratar da supremacia racial, conforme citado por Bentes (1993). De acordo com autores que dialogam sobre a temática, o racismo assim como a identidade, é uma construção ideológica, que permeia a ideia de que a sociedade é construída por raças biológicas, que segundo Jorge Silva (2008), estão em períodos de evolução diferentes.

Essa síntese corrobora para que a sociedade absorva que há a referida supremacia racial, com os brancos ocupando a parte superior da pirâmide e os negros na parte debaixo dela. Esse pensamento favorece também a dominação de um determinado grupo sobre o outro que é tido como inferior, da mesma forma que aconteceu no período da escravidão, através da exploração dos negros escravizados no trabalho.

$\mathrm{E}$ mesmo que se comprove biologicamente, que a sociedade não é formada de raças biológicas, o racismo ainda será um fato consumado socialmente e de maneira hostil. A luta contra o racismo tem o papel de disseminar que traços fenotípicos, a ancestralidade, a cor da pele e muito menos a aparência diferenciada não são portadores do caráter do indivíduo, da sua cultura e nem tão pouco do seu entendimento intelectual. Tendo em vista, que 
essas sinalizações, não podem servir para caracterizar um grupo e o expor de maneira discriminatória socialmente.

No caso brasileiro, vamos ficar com os componentes "raça" (não raça biológica), e "cor", associada a outros traços fenotípicos indicativos de ancestralidade africana, para entender o racismo brasileiro como a afirmação da superioridade da 'raça branca' sobre a 'raça negra', e a hierarquia das pessoas e grupos de acordo com a gradação de cor da pele, isto é, quanto mais 'preto' (ou menos branco), mais inferior. (Silva, 2008, p. 29)

Já o racismo é fruto da aversão de um grupo que se enxerga de maneira suprema, que denomina sua raça como superior, o que pode resultar no ódio. A vontade de se impor como raça superior e também como uma crença verdadeira e única, que se manifesta como um ato discriminatório, podendo atingir o máximo da violência, como agressão e assassinato, se resulta no racismo.

O racismo é uma questão estudada por vários pesquisadores. Alguns deles, como Edson Borges, Carlos Alberto Medeiros e Jacques d'Adesky (2002), afirmam que o racismo é um comportamento social que está presente na história da humanidade e que se expressa de variadas formas, em diferentes contextos e sociedades. Segundo eles, o racismo se expressa de duas formas interligadas: a individual e a institucional. (Lino, 2012, p.52)

A Campanha da Fraternidade de 88 através do seu manual teve a preocupação de salientar que o negro sofre racismo na estrutura de classes e que isso afeta suas relações sociais. $O$ texto base atenta para a exposição que o negro sofre devido ao sistema capitalista, agregando duas condições que os colocam em situação desigual, que é a pobreza, que assola majoritariamente a população negra e o racimo de fato. Sinalizando também, que o racismo é um ato velado e que isso dificulta ainda mais a superação dessa ação social negativa que o negro está acometido.

Decorrente das conceituações ressaltadas acima, se deve compreender que o preconceito racial e a discriminação racial, são frutos do racismo, ou seja, é inevitável dialogar sobre alguma dessas ações negativas que assolam a população negra, sem beber da fonte do racismo, mesmo entendendo que essas palavras não são sinônimas. Jorge Silva (2008) demarca esse entrelaço, apontando que o preconceito racial é o sentimento calcado na estereotipação do outro, que não afeta de maneira intensa a vida da população negra.

Já a discriminação racial, afeta de maneira agravante a vida do negro, pois, ela é o instrumento do preconceito, que nem sempre vem velado. E já o racismo é o ato de afirmar que há sim uma superioridade da denominada "raça branca" em relação às outras "raças" socialmente analisando. Logo, o diálogo que envolve as demandas da questão racial, não é consumado sem que haja o 
entendimento de que esses termos e conceitos, estão interligados e que geralmente, um não está dissociado do outro em suas práticas de exposição negativa ao negro.

Esse entendimento salienta a colocação de Octavio lanni (2004), que ressalta a vivência do mito da democracia racial no Brasil, que é proveniente do processo de miscigenação que o país teve. Que faz com que a militância seja algo imprescindível para a população negra, a fim de encontrar formas de disseminar a igualdade racial, assim como extinguir ou reduzir o racismo estrutural.

Desse modo, torna-se importante entender que a questão do Brasil viver o mito da democracia racial não favorece a população negra, que ainda hoje é oprimida, discriminada, marginalizada, subalternizada, menosprezada e estigmatizada. O que favorece todo o sentimento e ações que desqualificam o negro, contribuindo de maneira efetiva para o processo de divisão social.

Trata-se de elaboração psicossocial e cultural com qual a "marca" transfigura-se em "estigma", expresso em algum signo, emblema, estereótipo, com o qual se assinala, demarca, descreve, qualifica, desqualifica, delimita ou subordina o "outro" e a "outra", indivíduo ou coletivo. (Ianni, 2004, p.23)

A importância de compreender que o mito da democracia é algo que não contribui para a melhor aceitação do negro socialmente transcende do ato de mascarar a desigualdade racial. Colaborando para uma leitura romantizada da história do negro, que é permeada por exploração e maus tratos, contribuindo para que grande parte da sociedade interiorize que houve certa cordialidade no período da escravidão, conforme sinaliza o manual da Campanha da Fraternidade de 88.

O fato de expor que a democracia racial existe, e que ela não é um mito, torna-se perigoso para o andamento da luta em prol da igualdade racial. Pois, corre-se o risco de proferirem, que o Brasil é democrático em relação às demandas referentes à questão racial, pelo motivo, da população negra saber seu lugar, saber em quais espaços habitar.

Com isso, compreende-se que a Pastoral Afro-brasileira desenvolve o papel de agente social, interventor da questão racial e tem sua reflexão social pautada no preconceito, discriminação e racismo. Reforçando a afirmativa que fora proferida algumas vezes na pesquisa, que a Campanha da Fraternidade e a consumação de uma Pastoral voltada às demandas do negro, foram um reparo social da Igreja Católica para a população negra, ou seja, um pedido de desculpas para esse "povo". Assemelhando-se com as políticas de 
reconhecimento, redistribuição de renda e de ação afirmativa, que têm o caráter de reparação social, devido ao período da escravidão, conforme ressalta a autora Andréia Clapp (2010).

"As políticas de viés afirmativo são uma resposta às exigências feitas por grupos sociais como negros, mulheres, homossexuais, entre outros, por direitos coletivos e culturais. No caso do Brasil, esses grupos, que vêm se organizando como movimentos sociais principalmente a partir das décadas de 1980 e 1990, têm lutado não só por direitos que historicamente Ihes têm sido negados, como também pelo reconhecimento de suas especificidades enquanto grupo social". (Clapp, 2010, p. 138)

A Pastoral Afro-brasileira, como já mencionado, focaliza sua articulação na questão do racismo que faz parte do cotidiano da população negra e transforma a questão racial em um dos maiores dilemas do mundo moderno. Juntamente com a intolerância religiosa, com a homofobia, desigualdade social e de gênero, dentre outras mazelas das expressões da questão social. (Octavio lanni, 2004).

Consumando então, que as diferenças hereditárias e inatas são advindas do individualismo de grupos sociais, que reproduzem todas essas ações negativas que já foram citadas e contextualizadas. Esses grupos fizeram com que a escravidão fosse tida como uma prática social, demarcando por estigmatizações, subalternidades, discriminações e exploração no trabalho à população negra. (Antônio Sérgio, 2004). 


\section{A gênese da Pastoral Afro-brasileira no olhar dos seus protagonistas}

A pesquisa além de analisar a gênese da Pastoral Afro-brasileira e identificar a sua ação na questão racial, visa também, apontar os principais protagonistas da PAB e reconhecer qual a visão de cada um desses articuladores sobre a identificação que a questão racial tem nas ações desenvolvidas pela Pastoral.

A Pastoral Afro-brasileira é composta por alguns protagonistas, denominados como líderes religiosos e leigos, que organizam as ações da PAB tidas como concretas dentro da Igreja Católica. No que se refere à importância de lideranças leigas e não leigas na Pastoral Afro-brasileira, existem diversas pessoas que podem ser reconhecidas no seu processo de formação, porém, os quatro entrevistados foram previamente determinados tendo em vista a efetiva participação na fase inicial de construção da Pastoral e por serem reconhecidos como protagonistas desse processo. São eles:

- Padre Jurandyr - Líder religioso

- Frei Tata - Líder religioso

- Cecília - Membro leigo

- Dona Zica - Membro leigo

Os membros leigos escolhidos para realizar a entrevista, foi Dona Zica e a Senhora Cecília, que são consideradas protagonistas do processo de construção da PAB no Rio de Janeiro, por sua atuação efetiva e por serem reconhecidas como líderes leigas e que serão apresentadas posteriormente. E os líderes religiosos optados, foi o Padre Jurandyr Azevedo Araújo por ser um dos ativistas religiosos que impulsionou a criação da Pastoral Afro-brasileira e por ter sido o assessor nacional da PAB durante anos. E o Frei Athaylton Jorge Monteiro Belo, conhecido como Frei Tatá, como segundo líder religioso, por ser atuante e presente nas ações da PAB no Rio de Janeiro desde a construção da Pastoral Afro-brasileira.

Para ter acesso a esses protagonistas, participei de algumas articulações realizadas pela Pastoral Afro-brasileira no Rio de Janeiro e visitei na cidade de Belo Horizonte - MG, o assessor nacional Padre Jurandyr. Durante a pesquisa empírica, tive contato com núcleos da PAB de três Estados diferentes, como Rio 
de Janeiro, Curitiba e São Paulo (Pastoral Afro-brasileira Achiropita), o que enriqueceu a pesquisa, além de proporcionar um maior entendimento da articulação da Pastoral, que são diferenciadas em cada região.

\section{1}

\section{As perspectivas sobre a Pastoral Afro-brasileira na visão dos líderes religiosos}

A Pastoral Afro-brasileira tem como objetivo central, intervir nos atos perversos que já foram mencionados ao longo da pesquisa, como a discriminação racial, preconceito racial e racismo, que até hoje assolam a população negra. Mas, para que a PAB obtenha êxito nas suas ações concretas, torna-se imprescindível que protagonistas atuem na articulação dessas ações, pensando formas pertinentes de combate a esses atos e pensamentos racistas.

Com isso, através da pesquisa empírica em alguns núcleos da Pastoral Afro-brasileira existentes, identifiquei protagonistas que atuam desde a gênese da PAB e persistem na militância até os dias atuais. Padre Jurandyr, assessor ${ }^{15}$ nacional da Pastoral Afro-brasileira, desde a sua criação e o Frei Tata que pertence a Paróquia Nossa Senhora da Conceição e Paróquia Nossa Senhora Aparecida, ambas localizadas no bairro de Nilópolis no Rio de Janeiro.

Padre Jurandyr além de ser assessor nacional da Pastoral Afro-brasileira, também disserta através de artigos sobre os objetivos, atuação e compromisso social da PAB. Nesses artigos, o mesmo ressalta com frequência o convite que Deus faz para os cristãos através de leituras bíblicas ou não, a ser solidário a população que vive em situação de exclusão social, extrema pobreza e que é discriminada por serem marcadas por suas diferenças, tidas como inferiores na sociedade.

Respondendo ao chamado do Papa Francisco que nos convida a "...despertar nossa consciência, muitas vezes adormecida diante do drama da pobreza, para entrar mais no coração do Evangelho, onde os pobres são os privilegiados da misericórdia divina". Como também o convite de "ir à frente, saber tomar a iniciativa sem medo, ir ao encontro, procurar os afastados e chegar às encruzilhadas dos caminhos para convidar os excluídos. (Araújo, 2015, p. 01)

\footnotetext{
15 ...hoje a PAB tem sua orientação nacional a partir de SP. O Padre Enes responde pela Pastoral".
} (TATA, 2017) 
Mediante ao chamado dos ensinamentos cristãos e da militância que a identidade negra desperta em alguns indivíduos, assim como, os protagonistas religiosos Padre Jurandyr e Frei Tatá, se envolveram com a militância cristã através da Pastoral Afro-brasileira. Intervindo e articulando ações em prol da luta contra o racismo, que também envolve a Igreja Católica, assumindo a responsabilidade social, que todo ser humano deveria exercer em busca de uma sociedade mais justa e igualitária, independente de ser cristão ou não.

Para o andamento da Pastoral Afro-brasileira é extremamente necessário que o clero seja concordante com as ações da PAB, assim como, terem Padres que militem próximos dos membros leigos. E dessa forma, aconteceu com os líderes protagonistas Padre Jurandyr e Frei Tata, ambos analisaram de forma bem intimista a importância que a Pastoral tem no âmbito religioso e social.

Considerando essa análise que enfatiza o trabalho em conjunto da Igreja Católica com os cristãos, Frei Tata, relata que: "A PAB conta com o apoio dos Padres, Bispos e Diáconos negros organizados em um Instituto chamado IMA. Instituto Negra Mariama". O que permite um diálogo mais expandido sobre a questão racial dentro da Igreja Católica, conforme almejado pelos membros e líderes da Pastoral Afro-brasileira.

Porém, Padre Jurandyr em seu diálogo sobre a importância da existência da Pastoral Afro-brasileira dentro da Igreja Católica, atenta para a questão da instituição ainda não discutir abertamente determinadas temáticas, como por exemplo, a questão racial que engloba várias expressões e que é um dos dilemas da modernidade, considerado por Octavio lanni (2004). Padre Jurandyr aponta que a participação do clero, não é unânime em todas as dioceses do Brasil, embora exista Pastoral Afro em todas elas.

Podemos dizer que no Brasil existe Pastoral em todas as dioceses, sendo que um bom grupo não está ligado à Igreja pela dificuldade de bispos ou sacerdotes ou religiosos aceitarem essa Pastoral, mas ela existe e às vezes os grupos são bem organizados. Os demais são organizados e orientados pela própria Pastoral. Cada um tem seu trabalho específico com a comunidade negra. Hoje estamos desenvolvendo já um trabalho com os Quilombos. Foi feito um subsídio de estudo número 45, sobre a Igreja e os Quilombos.

Tendo a preservação da identidade cultural do negro e a luta do combate aos atos e expressões racistas, como base de atuação da Pastoral Afro-brasileira, conforme assinala Rosangela Borges (2001). Padre Jurandyr, também analisa o quão valorável é a consideração da autora demarcada através da sua fala durante a entrevista. 
"A Pastoral é para dar consciência sobre a diversidade cultural, sobre a presença do negro desde o início da nossa Pátria e as consequências da escravidão que durou 400 anos. Também dentro da lgreja e as questões da religiosidade popular do povo negro. O que a Pastoral faz é no sentido de articular os grupos".

A importância de conscientizar e edificar a história do negro, iniciou antes do período dos APNs, na verdade foram desses diálogos que emergiram os APNs. E foi nesse momento de mobilização dentro da Igreja Católica, advinda dos negros cristãos, que instaurou articulações favoráveis a questão social, para que a comunidade entendesse o protagonismo que a população negra tem na influência da cultura do Brasil, assim como estimular o respeito às diferenças provenientes da construção social, pertencente a cada grupo.

Como eixo de articulação deste novo processo de conhecimento, partilhas, formação, discussão política, teológica e organização popular neste período, é que nasce os Agentes de Pastoral - APNs. Como um grupo de conscientização e buscando a verdadeira identidade do negro e da negra no espaço da fé, dentro e fora da Igreja. (Silva, 1993, p. 08)

As práticas adotadas pelos APNs, para exaltar a temática racial se assemelham com as ações concretas articuladas pela Pastoral Afro-brasileira. Porém, atualmente com a PAB são realizados Congressos, Encontros e Caminhadas que abordam temas referentes a questão racial, assim como, temas concernentes às expressões da questão social, que assolam a população negra majoritariamente, de acordo com Padre Jurandyr.

"Estamos trabalhando nisso. Estamos organizando o IX Encontro da Pastoral Afro-
brasileira (IX CONENC). Temos parceria com outros grupos, por exemplo, os
Agentes de Pastoral Negro (APNs), o Instituto Mariama, que congrega bispos,
padres e diáconos negros. Podemos dizer que há sempre uma relação com esses
grupos, não só da Igreja, como também da sociedade civil".

É importante atentar nas declarações dos protagonistas da Pastoral Afrobrasileira, a responsabilidade social que a PAB exerce na sociedade civil, como sinalizado na consideração anterior do Padre Jurandyr. Mas, não se pode esquecer de que esse compromisso, nem sempre esteve presente nas preocupações e nas intervenções da Igreja Católica, pelo contrário, essa foi uma percepção que aflorou a partir do Concílio Vaticano II, fortalecida a seguir, nas Conferências de Medellín e Puebla. (Campanha da Fraternidade de 1988)

Outro ponto que demarca a reflexão social da Pastoral Afro-brasileira, que culminou antes mesmo da consumação da Campanha da Fraternidade de 88, que teoricamente comemorava a celebração dos 100 anos da Abolição da Escravatura. Esse feito que pode ser considerado uma das comprovações da responsabilidade social que a $\mathrm{PAB}$ dispõe, visto que, o racismo é um problema 
social. A Romaria também é tida como uma ação concreta articulada pela Pastoral Afro-brasileira.

A Romaria teve início no ano de 1996, na Basílica de Nossa Senhora Aparecida, em Aparecida do Norte em São Paulo. Ela acontece no primeiro sábado do mês de novembro, que é reconhecido principalmente entre a população negra, como mês da Consciência Negra, por celebrar Zumbi dos Palmares no dia 20. Ele é a representatividade da resistência do negro, pois, Zumbi foi uma das figuras que mais lutou pela libertação dos negros escravizados, abrigando em seu Quilombo mais de 20.000 escravizados que fugiram.

\footnotetext{
"Na saga pela libertação, Zumbi estabeleceu a república do Quilombo dos Palmares, a mais bem-sucedida aventura libertária do povo negro. Palmares resistiu quase 70 anos às expedições enviadas pelas autoridades governamentais. Chegou a abrigar em torno de 20.000 escravos fugidos. Foi destruído em 1693 por um exército de mais de 6.000 soldados mercenários e assim mesmo porque, após um mês de cerco e munição e os víveres acabaram". (Texto base da Campanha da Fraternidade de 1988, p. 55)
}

Considerando que todas essas ações articuladas pela $P A B$ são pertinentes para a conscientização da negritude, porém, elas não se tornam isentas de todas as dificuldades, que assolam as demandas da população negra. Ao dissertar sobre a Romaria, Padre Jurandyr aponta a riqueza que traz cada ação concreta, assim como, as dificuldades imbuídas nessas ações, salientando também o posicionamento resistente que os protagonistas envolvidos com a Pastoral devem desenvolver nessa vida de militância.

\begin{abstract}
"A Romaria em Aparecida no primeiro sábado do mês da consciência negra. Nesse ano é a diocese de Mogi das Cruzes que está preparando a Romaria e o tema é "Escravos ontem, escravos hoje também na Igreja". O trabalho pode ser lento, mas é um trabalho de base. Sobretudo a partir de 2015, no segundo Congresso Nacional, estamos preparando lideranças e essas lideranças estão atuando em cada estado, em cada comunidade e diocese. Esse é o grande trabalho hoje de lideranças".
\end{abstract}

E por falar em lideranças, no ano de 2018, após alguns anos consecutivos, a Pastoral Afro-brasileira terá um novo assessor nacional, desse modo Frei Tatá também atenta para outras representatividades que vão fazer parte do calendário da PAB "No ano de 2018, a PAB vai comemorar 30 anos, se tomarmos como referência a Campanha da Fraternidade de 1988 histórica”. Já o Padre Jurandyr, sinaliza que além da mudança do assessor e a comemoração dos trinta anos de PAB, em 2018 também vai ocorrer o Congresso Nacional das Entidades Negras Católicas. 
"Também o próximo ano (2018) vai ser em janeiro de 2018, na arquidiocese de Maringá (PR). Estamos preparando para que outras lideranças participem. É um trabalho que vai continuando no sentido de uma perspectiva de abertura".

A mudança do assessor nacional da Pastoral Afro-brasileira que vai ocorrer no ano de 2018, foi decidida na última assembléia, que ocorreu em Aparecida do Norte, no mês de julho de 2017. A sede da PAB, que era localizada em Belo Horizonte e estava sendo coordenada pelo Padre Jurandyr, migrou para São Paulo e com isso, terá um novo assessor, de acordo com as sinalizações do mesmo.

"O bispo auxiliar Dom Eduardo vai assumir essa Pastoral e o Padre José Henri é que vai internamente assumir o Pastoral. Porque estou realmente deixando essa pastoral pelo tempo e acho importante a mudança. Portanto, eu e o Padre Fernando daremos continuidade a essa Pastoral até o fim do ano em algumas tarefas que iniciamos".

Contudo, é relevante entender a partir da percepção dos líderes religiosos, aqui mencionados, a importância da Pastoral Afro-brasileira no âmbito religioso, decorrente de toda a trajetória racista e discriminatória que demarcam a história da Igreja Católica. Influenciando a trajetória de construção da gênese da Pastoral, sendo pontuado de acordo com a vivência e atuação de cada um dos líderes religiosos envolvidos com a PAB.

\subsection{1}

\section{O surgimento da Pastoral Afro-brasileira através do olhar dos líderes} religiosos

Embora a Campanha da Fraternidade de 1988, seja o marco que demarca a data de surgimento da Pastoral Afro-brasileira para a maioria dos envolvidos, essa questão ainda gera incompatibilidade de informações vindo dos seus protagonistas. Um dos principais motivos dessa divergência de datas provém da denominação da PAB como o resultado da movimentação dos negros, surgidos em momentos anteriores dentro da Igreja Católica. (Rosenilton Oliveira, 2016)

“(...) O texto base da CF de 1988 diz que a ideia da pastoral surgiu na década de 1970, quando dom Helder Câmara realizou a missa dos quilombos. O documento número 85 da série Estudos da CNBB (Pastoral Afro-brasileira) apresenta o ano de 1988, como sendo marco inicial; já os coordenadores, localizam seu início entre os anos de 1986 e 1988". (Oliveira, 2016, p.77)

A pluralidade em relação aos movimentos sociais, que se alastrou na década de 80, corrobora para que o início da Pastoral Afro-brasileira tenha de 
fato como marco inicial, a Campanha da Fraternidade de 88. Até mesmo, pelo fato da Igreja Católica já ter passado pelos períodos em que iniciou priorização pelo social em suas ações cristãs, como o período da Concílio Vaticano II, Conferência de Medellín, Teologia da Libertação e Conferência de Puebla.

No entanto, na concepção e vivência do Padre Jurandyr, a movimentação na Igreja Católica em relação à questão racial, iniciou em 1978, com a militância de um Padre negro. Mestre em Filosofia da educação, Antonio Aparecido da Silva, o Padre Toninho, antes de se tornar referência na história da Pastoral Afro-brasileira, passou por situações discriminatórias durante sua tentativa de ingressar na vida eclesial.

A cor retinta da pele negra do Padre Toninho, quase o excluiu da vida sacerdotal, pois, antes do Concílio Vaticano II, era ainda mais latente o racismo dentro da Igreja Católica e com isso, haviam poucos seminaristas negros. Mas, de acordo com relatos de membros da Pastoral Afro-brasileira Achiropitae do ex aluno do Padre Toninho, o mesmo não se abateu e manteve sua militância em prol da igualdade racial.

"De tudo que aprendi de Pe. Toninho e levarei sempre, fica principalmente a leveza e a ternura no trato das questões étnicos-raciais, sem perder a segurança de denunciar o racismo onde não se espera encontrá-lo, mas também a fé no Quilombo, Páscoa-Ressureição do Reino da igualdade, na irmandade quilombola daqueles e daquelas que sonham, lutam, celebram e dançam na utopia de um mundo justo e igualitário". (Passos, 2013, p. 03)

Para contextualização da gênese da Pastoral Afro-brasileira cabe ressaltar que a oficialização derivou de Brasília, onde está localizada a Conferência Nacional dos Bispos do Brasil (CNBB). Local para onde foram convocados alguns padres para construir subsídios que demandasse questões referentes à situação social da população negra. De acordo com Padre Jurandyr.

Em 1982 começou a secretaria da Pastoral na sede em Brasília. Essa Pastoral começou a se organizar. À secretaria da CRB Nacional doou os móveis e a irmã Raimunda da Congregação Jesus Crucificado ficou como secretária.

A divergência no momento de datar o início da Pastoral Afro-brasileira, também foi identificada nos relatos dos líderes religiosos entrevistados. Frei Tata, demarcou o surgimento da PAB através do trabalho desenvolvido pelas Comunidades Eclesiais de Base $(\mathrm{CEBs})^{16}$ e pelo Encontro de Pastoral Americana (EPAs).

\footnotetext{
${ }^{16}$ Segundo Frei "As comunidades eclesiais de Bases (CEB's) são pequenos grupos organizados em torno de uma paróquia (urbana) ou capela (rural), por iniciativas de leigos, padres ou bispos".
} 
"A pastoral neste início contou com uma Igreja que acreditava nas Comunidades Eclesiais de Base. Contamos com bispos corajosos como: D. Helder Câmara e de D. José Maria Pires recém-falecido. A PAB se organizou nos Regionais da CNBB, no Continente a partir dos grandes encontros chamado: EPA. Encontros de Pastoral Afro Latino Americano".

As duas referências que Frei Tatá considerou para sinalizar o início da Pastoral Afro-brasileira, também tem seu lugar de destaque na luta em prol da igualdade racial. A CEBs, surgiu aproximadamente em 1960 e são consideradas comunidades, por agregar pessoas da mesma localidade, da mesma Igreja e que compartilham da mesma fé. Os membros também partilham das mesmas questões sociais, que envolve a luta por melhores condições de vida, o que abrange também a questão da discriminação. (Frei Betto, 1981)

"São eclesiais, porque congregadas na lgreja, como núcleos básicos de
comunidade de fé. São de base, porque integradas por pessoas que trabalham
com as próprias mãos (classes populares): donas-de-casa, operários,
subempregados, aposentados, jovens e empregados dos setores de serviços, na
periferia urbana; zona rural, assalariados agrícolas, posseiros, pequenos
proprietários, arrendatários, peões e seus familiares". (Betto, 1981, p. 07)

Assim como as Pastorais, as CEBs têm como animadores, agentes pastorais como Padres, leigos e religiosos geralmente, que são pertencentes da própria comunidade local. Essas comunidades tiveram protagonismo no período da Ditadura Militar, se posicionando ao lado da população, ou seja, se colocam contra ao governo ditador e com isso, tiveram muitos dos seus articuladores torturados e presos.

Atualmente as CEBs tem sua reflexão evangelizadora pautada nas atividades sociais, se disponibilizando ao oprimido. Outra ligação que a Comunidade Eclesial de Base desenvolve é a ligação com os movimentos sociais, por isso, Frei Tatá também considerou a importância das suas ações como um início para a construção da Pastoral Afro-brasileira. Pois, as CEBs propõem em seus encontros, dialogar sobre questões que geralmente estão relacionadas as demandas sociais, o que permite o diálogo com os movimentos sociais locais, que intervém nas demandas expostas pela comunidade. Frei Tatá também mencionou o EPA, que é o Encontro de Pastoral Afro-americana, que iniciou em 1980, após alguns marcos histórico que antecederam a criação da PAB, como já fora mencionado, mas, em especial a Conferência de Puebla, que foi o momento que a Igreja Católica falou abertamente sobre os negros.

\footnotetext{
${ }^{17}$ Segundo Frei "As comunidades eclesiais de Bases (CEB's) são pequenos grupos organizados em torno de uma paróquia (urbana) ou capela (rural), por iniciativas de leigos, padres ou bispos".
} 
Todos os EPA abordavam assuntos de interesse da população negra, mesmo que a temática estivesse relacionada com a questão religiosa ou não.

O primeiro EPA aconteceu em Buenaventura (Colômbia) e contou com a presença de 50 pessoas, a maioria dos participantes eram Agentes de Pastoral. Esse Encontro acontece a cada três anos e aborda problemáticas diversas referentes à situação social e religiosa do negro. Alguns dos primeiros temas abordados e a quantidade de delegados participantes foram:

- 1ำTema no ano de 1980: Religiosidade Popular e Cultura Negra, com 50 participantes;

- 2o Tema no ano de 1983: Grupos Afro-americanos em Situação Rural e Urbana, com 104 participantes;

- 3ํTema no ano de 1986: Identidade e História do Afro-americano à Luz da História da salvação, com 150 participantes;

- 4ํ Tema no ano de 1989: A família Afro-americana, com 118 participantes;

- 5ํ Tema no ano de 1991: Educação e Pastoral Afro-americana, sem número específico de participantes

É notório que os temas abordados nos EPAs eram de extrema importância para os negros, que compareciam em números significantes. Os encontros tinham a solidariedade como base das suas reflexões, a caracterizando como um dos caminhos para alcançar o desenvolvimento das Comunidades Negras. Além do prestígio que os EPA tiveram com os movimentos sociais, suas reflexões e encontros também tiveram grande relevância, na construção da secretaria responsável pela articulação das ações concretas da Pastoral Afrolatino-americana e Caribenha, SEPAC.

Os EPAs, foram ganhando maior importância na medida em que o Movimento Negro foi tomando maior vulto na sociedade como um todo e na Igreja, em particular. É importante mencionar a grande colaboração do DEMIS-CELAM, através, sobretudo dos seus secretários executivos, no processo dos EPAs. Ao longo deste processo, duas ferramentas importantes foram construídas. "Uma foi a criação da secretaria de Pastoral Afro-latino-americana e Caribenha (SEPAC). (EPA, 1999, p.12)

As considerações sinalizadas pelos líderes religiosos a respeito da construção da Pastoral Afro-brasileira são plausíveis para demarcar o seu processo de surgimento, porém, a Campanha da Fraternidade ainda é fortemente considerada o marco principal da criação da PAB. Ressaltado por alguns líderes pertencentes da Pastoral, como o próprio Padre Jurandyr, assinalando em suas considerações, que a movimentação para a criação da 
PAB, adveio da importância de celebrar os 100 Anos da Abolição da

Escravatura.

Justamente em 1987 já estava no processo para a celebração de 100 anos da abolição. E então houve a proposta da Campanha da Fraternidade em 1988. Essa Campanha da Fraternidade foi organizada pela Pastoral. Fizemos um texto base e passamos em muitas dioceses conversando sobre isso. Em 1988 foi um marco para a Pastoral Afro-brasileira. A partir de 1988 começou essa organização.

Antes da consumação da Campanha da Fraternidade de 1988, de acordo com o que já foi mencionado, houve uma movimentação dos APNs, para que a temática sobre a questão racial fosse mais presente na Igreja Católica. E foi nesse momento que muitas lideranças religiosas, leigos e padres iniciaram a sua militância na Igreja, assim como, Frei Tatá, que relatou sobre o início do seu ativismo em prol da igualdade racial "Há 27 anos. Antes de sermos a PAB, éramos APNs (Agentes de Pastoral Negros)."O início da sua militância, foi em um momento em que os negros cristãos clamavam muito por espaço dentro da Igreja Católica e por isso, deram início a criação dos APNs.

Junto à necessidade de abrir um espaço no interior da Igreja e "acolher o negro como tal", somou-se a dificuldade de definir quem é o negro católico. Podemos destacar, no final do século XX, três momentos da inclusão do negro na Igreja Católica: o surgimento e articulação dos APNs, a Campanha da Fraternidade de 1988 e a criação da Pastoral Afro. (Oliveira, 2016, p. 53)

A articulação que os APNs desenvolviam dentro da Igreja Católica, também fazia parte do discurso da maioria dos membros da Pastoral Afrobrasileira, principalmente quando o questionamento era sobre o início da PAB. A Senhora M, membro da Pastoral Afro-brasileira Achiropita, adenda que os cristãos negros participantes dos APNs, tinham bastante envolvimento político e com o passar do tempo a participação como Agentes de Pastoral Negros, ficou mais restritos e os paroquianos começaram a não saírem muito das suas paróquias para militar.

E em relação a trajetória de envolvimento com a questão racial no território da Igreja Católica, Padre Jurandyr assinala a importância do Movimento Negro Unificado (MNU) “Comecei após minha ordenação sacerdotal, em 1973, no Rio de janeiro a participar do MNU para tomar consciência da minha negritude, porque minha formação dentro da Congregação eu era branco ou pardo". O MNU teve muita representatividade em relação as lutas em prol da igualdade racial na década de 80 e inspirou muitos militantes, inclusive membros da Pastoral Afro-brasileira atuantes. 
Ainda no início da construção do diálogo sobre a negritude e suas demandas dentro da Igreja Católica, muitas das ações interventivas do MNU foram analisadas por membros leigos, religiosos e padres da Igreja, a fim de subsidiar a problematização sobre a situação de desigualdade que a população negra estava exposta dentro da própria instituição.

\begin{abstract}
"A bandeira erguida nos anos 80 , nas praças, nas universidades e no campo político democrático pelo Movimento Negro Unificado (MNU) caracterizava a base propulsora do Movimento Negro que, em suas atuações, reivindicava, medidas de combate ao racismo e da discriminação racial, que examinadas por padres, leigos, leigas e bispos negros corajosamente, iniciam fortes reflexões no sei da Igreja face a problematização da pobreza e da desigualdade racial da população negra no Brasil" (Paixão, 2013, p.01)
\end{abstract}

A Pastoral Afro-brasileira foi resultado de uma série dessas movimentações dentro da Igreja Católica, conforme já foi explorado ao longo da pesquisa e assim como relata Padre Jurandyr discorre em relação ao início da sua militância dentro da Igreja. Ele relata, que após passar oito anos trabalhando na Angola e ao voltar para o Brasil se envolveu com grupos que visava à conscientização negra na Igreja Católica.

\begin{abstract}
"Ao voltar em 1983, comecei a participar do grupo "União Consciência Negra" que era da Igreja. E aí comecei em 1987 esse trabalho. São mais de 14-15 anos nesse trabalho. R nós estávamos, até 2015 , na Sede da CNBB. Tínhamos a secretaria lá e era muito importante como aspecto pedagógico para que a gente pudesse também ajudar todas as Pastorais das Igrejas a repensar as suas práticas com relação ao povo afro-brasileiro".
\end{abstract}

E de acordo com as considerações aqui expostas, percebe-se que a militância dos negros cristãos, não é recente, pelo contrário, eles apenas não tinham o espaço que precisavam dentro da Igreja Católica. Pois, percebe-se que foi grande a articulação dos negros que estavam inseridos na instituição e que buscavam evidenciar a cultura e identidade afro, seja através de ações concretas, diálogos e cursos de formação.

\title{
3.1 .2
}

\section{A importância das atividades da Pastoral Afro-brasileira na perspectiva dos líderes religiosos}

Os grupos formados por negros cristãos se organizavam para debater sobre as demandas da questão racial e almejavam inicialmente notoriedade dentro da Igreja Católica abordando suas reivindicações. Mas, essa notoriedade 
exigia que houvesse atividades concretas evidenciando a cultura e identidade afro-brasileira. E essa era a tarefa de maior importância que esses grupos desenvolviam enquanto disseminadores da igualdade racial, assim como os precursores da Pastoral Afro-brasileira, os APNs,

"Como eixo de articulação deste novo processo de conhecimento, partilhas, formação, discussão política, teológica e organização popular neste período, é que nasce os Agentes de Pastoral - APNs. Como um grupo de conscientização e buscando a verdadeira identidade do negro e da negra no espaço da fé, dentro e fora da Igreja". (Silva, 1993, p. 08)

Desta forma, a Pastoral Afro-brasileira desenvolve em caráter de importância as ações concretas, que foram pautadas através das sugestões advindas do manual da Campanha da Fraternidade de 1988, que subsidiou os documentos da CNBB, que direcionam as atividades e exercício da PAB. Esse direcionamento é sinalizado no texto base da CF de 88, que aponta que as ações concretas que a Igreja Católica deve ter com a população negra, é fruto do reconhecimento de um pecado histórico.

O manual da Campanha da Fraternidade de 88 também expõe que a Igreja Católica deve em suas ações concretas em relação às demandas da questão racial, evidenciar seu pedido de perdão ao negro, por ser conivente com a prática da escravidão durante anos, sem denunciá-la. Assim como, não ter agido contra a discriminação da população negra no seu seio, o que só corroborou para que o negro não se identificasse como membro da instituição.

Em decorrência dessa percepção da Igreja Católica, em relação a sua postura em relação a população negra, o texto base da Campanha da Fraternidade de 88, aponta como sugestões de ações concretas: o pedido de perdão ao negro por sua conivência a prática da escravidão; o ato de superar sinais de racismo na Igreja; libertar agentes de Pastorais negros para atuarem apenas nas Pastorais específicas da sua população; promover e apoiar grupos negros; introjetar na vida da Igreja a cultura e causa negra e impulsionar o diálogo inter-religioso.

Essas sugestões derivadas do manual da Campanha da Fraternidade comprova a consideração exposta por Padre Jurandyr, que assimila a importância das ações concretas exercidas pela Pastoral Afro-brasileira, aos desafios provenientes das demandas sociais. Ele aponta que a importância dessas ações provém do racismo social: "Porque ainda no Brasil existe racismo, então é preciso trabalhar". 
Assim como o Padre Jurandyr, Frei Tatá assinala que o racismo é o maior provedor da importância articuladora da Pastoral Afro-brasileira. Visto que, a postura racista da sociedade é proveniente da escravidão e a Igreja Católica, não se colocou contrária a essa prática, portanto, entende-se o motivo dos líderes religiosos denominarem o racismo como a maior causa da importância das ações concretas da Igreja, conforme sinaliza Frei Tata.

"A importância da $P A B$ em especial, continua sendo a luta da superação do racismo dentro e fora da Igreja. Hoje, a luta contra a intolerância religiosa. A luta contra a morte da juventude negra. Na Igreja de forma particular, é continuar a luta por uma Igreja que fez uma "opção preferencial pelos pobres". Pois aqui, negros e negras são maioria dentre os pobres! Está decisão da Igreja passa pela Conferência de Puebla em 1979".

Os materiais referentes a Pastoral Afro-brasileira, também apontam o racismo e a discriminação como base da atuação da Pastoral. Enxergando a necessidade da articulação em prol da igualdade racial no âmbito religioso e social, que além de ser um dos maiores anseios que fez surgir a PAB, considerase também, que são os principais componentes das ações interventivas da Pastoral.

(...), a condição de discriminação e exclusão em que vive a maioria deles e as muitas atividades surgidas na esfera pastoral, por iniciativas dos próprios agentes negros, com o apoio das Igrejas locais, levaram à criação da Pastoral Afrobrasileira, vinculada à Dimensão sócio transformadora. (CNBB, 2002, p. 39)

E embora as ações concretas da PAB sejam de extrema importância para a luta em prol da igualdade racial, não a isenta de passar por diversos desafios, até mesmo dentro da Igreja Católica. Esses desafios derivam geralmente das ações articuladoras da Pastoral Afro-brasileira, que tem como missão, proporcionar a comunidade paroquial e local uma maior vivência a partir da tradição da lgreja, dos valores da cultura afro.

Um dos grandes desafios apontados pela Pastoral Afro-brasileira, é que a Igreja Católica entenda que há múltiplas expressões culturais, respeitando a diversidade de cada "povo". Até mesmo pelo fato da população negra ter grande influência na formação cultural, social, política, econômica e religiosa do país, esse apontamento foi feito no II Seminário de Teologia da Pastoral Afro-brasileira em 2010, concluindo também que esses desafios requer uma mudança permanente e integral na articulação sobre a questão racial.

"O Brasil tem dívida para com a África. As Igrejas podem crescer mais com as comunidades afro-brasileiras, de forma efetiva e comprometida com a sua casa, 
com ações afirmativas e políticas públicas e mudando psicologicamente a maneira de resgatar a dívida". (Araújo, 2010, p. 08)

E permeando as próprias considerações feitas por Padre Jurandyr nesse II Seminário de Teologia da Pastoral Afro-brasileira, o mesmo descreve em sua entrevista, que "Os desafios vêm da sociedade, por isso, temos que conscientizá-la das riquezas e dos valores das culturas afro-brasileiras". E visto que a lgreja é pertencente da estrutura social, Padre Jurandyr também denominada o processo de branqueamento, como um grande agravante dos desafios que a PAB está exposta.

"Ora a Igreja está dentro da sociedade e assim precisamos também trabalhar na Igreja porque há muitos leigos e leigas, sacerdotes, bispos e religiosos que ainda não aceitam a Pastoral Afro-brasileira por causa da questão do branqueamento que existe até hoje. Isso porque o padrão da sociedade e da Igreja é o padrão do branco e o negro sempre é tido como inferior, o negro não sabe, o negro não é capaz, o negro não trabalha direito".

O que significa que há uma teoria do branqueamento dentro da Igreja Católica, que é reconhecida no período da CF de 88, mas que não assola somente a Igreja, mas sim todo o âmbito social. Porém, esse foi um dos apontamentos que as considerações do texto base da referida Campanha ressaltou, sinalizando que essa superioridade do branco é de grande aceitação da elite, influenciando toda a sociedade, que teve grande aceitação entre os séculos XIX e XX, criando medidas de desaparecimento do negro, negando que haja uma sociedade multi-étnica.

Essa ideologia do branqueamento, ainda traz diversos danos para os negros, que sofrem com a falta de oportunidade e de espaço também, pois poucos são os lugares que permitem ao negro o espaço de fala, ou seja, os tratam como protagonistas. E essa situação é atentada pelos militantes cristãos, visto que, a Igreja Católica é um desses espaços, que não permite o total protagonismo da população negra, como nas leituras, coroações a Nossa Senhora, participação em peças e danças, contribuindo para o não pertencimento do negro dentro da Igreja, como é exposto por Frei Tatá.

"É a negação do negro e da negra no período pós Abolição. A constância na negação dos direitos de negras e negras! É uma Sociedade que teve a coragem de fazer de forma oficial o projeto de Ideologia do Embranquecimento. Uma sociedade que trouxe europeus em especial para o Sul do país em detrimento de negros e negras. Aos migrantes europeus o governo de terras. Para negros e negras, até hoje, a terra é um problema! As comunidades Quilombolas estão aí, cerceadas em seus direitos, ameaçadas na legalidade de suas terras". 
As declarações dos líderes religiosos envolvidos com a Pastoral Afrobrasileira, contemplam a consideração de Florestan Fernandes (2008), que disserta sobre a perpetuação dos padrões raciais, da relação estabelecida socialmente, que determina que o padrão social seja o branco. Essa análise é fruto da prática da escravidão, que se estabelece até hoje e que determina que o negro seja visto constantemente em situação de inferioridade, não ameaçando o branco em nenhuma relação de poder e protagonismo.

"Por isso, na raiz desse fenômeno não se encontra nenhuma espécie de ansiedade ou de inquietação, nem qualquer sorte de intolerância e de ódios raciais, que essas duas condições fizessem irromper na cena histórica. Em nenhum ponto ou momento o "homem de cor" chegou a ameaçar seja a posição do "homem branco" na estrutura de poder da sociedade inclusiva, seja a respeitabilidade e a exclusividade de seu estilo de vida". (Fernandes, 2008, p. 304)

Essa relação de poder estabelecida socialmente, reflete no seio da Igreja Católica também, de acordo com declarações dos líderes religiosos, enfatizado por Frei Tata, que aponta que "As maiores dificuldades para a PAB em minha opinião é o enfretamento cotidiano do racismo dentro e fora da Igreja ainda hoje". Porém, o Frei atenta para outra demanda que assola a população negra, que é o "extermínio" dos negros, assim como a grande participação dos jovens negros no tráfico, proveniente da desigualdade social.

"A violência na sociedade em que os Jovens Negros são as maiores vítimas. O tráfego de drogas nas Comunidades, Milicianos... A falta de infra estrutura básica em nossas Comunidades, o atual desemprego. Ressalto dentro da Igreja a não aceitação da continuidade do trabalho de muitos grupos de base, a formação religiosa e sócio-político".

O que nos permite refletir sobre o estudo de classes, que é denominado por Marx, como o início da sua teoria sobre a luta de classes, conforme aponta Antônio Sérgio (2002). Ressalvo essa afirmativa, para expressar o quão importante é caracterizar a importância da Pastoral Afro-brasileira nas questões sócias, pois, a luta de classes envolve as transformações sociais, que é um dos maiores anseios da população negra, que sofre com a exacerbada desigualdade racial e social.

"O sucesso científico da teoria deveu-se, em grande medida, à articulação que ela propunha entre as esferas sociais - a economia, a sociedade, a política e a cultura - de tal modo que uma certa ordem prevaleceria sempre entre elas; o segredo de tal ordenamento devendo ser buscado na produção da vida material (na economia, em última instância)". (Guimarães, 2002, p. 35)

Esse também é um aspecto evidente no texto base da Campanha da Fraternidade de 88 , que demarca como herança do período da escravidão, a 
esteriotipação e marginalização que o negro carrega socialmente. Os expondo a situação de injustiça, luta pelo poder, cobiça e a situação de violência, por serem denominados no período em que eram escravizados, como violentos e recebendo a falsa identificação de seres inferiores, assim como de ignorantes e miseráveis.

Os líderes religiosos também apontam como um grande desafio no exercício das articulações da Pastoral Afro-brasileira, o diálogo inter-religioso. Que é reconhecido também, como uma das ações concretas de grande importância da PAB, por entrar em contato com a maior fonte de cultura do negro, que são as religiões de matriz africana, que evidenciam as expressões que identificam a população negra.

A religiosidade na vida do negro ocupa lugar de destaque e mesmo tendo sofrido supressão de direitos e não podendo expressar seus valores na época em que foram explorados e escravizados, os negros não perderam seus valores e identidades culturais. O negro dispõe do conceito de profunda religiosidade, como apontado no manual da CF de 88, analisando também, que a família da população negra, não era apenas constituída de pais, filhos e parentes, os antepassados também faziam parte, assim como, os elementos da natureza.

"O nascimento é um ato divino e a morte é vista também sob ótica religiosa. A ligação com os ancestrais, a vinculação com a Mãe-África projetada como "terra prometida" e sentida como "paraíso perdido" é garantia de identidade negra e fonte de resistência". (Texto base da Campanha da Fraternidade de 1988, p. 52)

E embora a religiosidade dos negros seja uma das principais fonte da sua cultura afro, ainda há discriminação em relação as religiões de matrizes africana, o que dificulta ainda mais que o diálogo inter-religioso seja consumado entre as ações concretas que a Pastoral Afro-brasileira desenvolve em sua militância. Faustino Teixeira (2014) discorre que essa não é uma dificuldade apenas para a $P A B$, ele explica que o diálogo inter-religioso é um grande desafio dos tempos atuais, por ser uma relação que envolve interlocutores diferentes.

O diálogo inter-religioso é um processo que constrói pautado no conhecimento entre ambos e na reciprocidade. Por isso, Padre Jurandyr classifica que esse diálogo é um dos grandes desafios enfrentado pela PAB principalmente dentro da Igreja Católica, porque muitos dos paroquianos identificam a prática de militar e evidenciar a cultura afro, como exaltação e consumação das práticas das religiões de matrizes africana, tendo o Candomblé e Umbanda como exemplo. Desta forma, Padre Jurandyr assinala que o: 


\begin{abstract}
"Segundo desafio é o diálogo inter-religioso. Nós temos então as religiões de matrizes africanas: o Candomblé que nasceu na África, veio para o Brasil e foi readaptado aqui; a Umbanda que nasceu no Brasil, em Niterói, é uma junção do espiritismo com as religiões de matrizes africanas e indígenas; a Quimbanda, um grupo menor que é uma junção da Umbanda e do Candomblé. Portanto, as pessoas têm muito preconceitos, sobretudo muitos grupos da Igreja, movimentos que acham que não é uma religião, mas coisa do demônio. Não é verdade; é uma religião como outras".
\end{abstract}

Permeando ainda o diálogo inter-religioso, evidencia-se a conquista do sincretismo religioso pelos negros, que exprime a junção dos seus ancestrais e Orixás e os Santos da Igreja Católica. Ressaltando, portanto, a importância do Candomblé que é caracterizado como uma religião de resistência, por juntar as diversas etnias africanas, com o propósito de salvar os negros escravizados. (Márcia Meireles, 2014)

E o esforço que a Pastoral Afro-brasileira tem para evidenciar o sincretismo alcançado pelos negros esteja presente nas ações, celebrações inculturadas e nos diálogos é notório principalmente nos cantos. Pois é importante salientar que o sincretismo cultuado pelo Candomblé, resistiu ao período escravocrata e vivia na ilegalidade, sendo até perseguido pela polícia, porém, guardou toda a ancestralidade, cultura e identidade da população negra, portanto, deve ser exaltado de maneira constante pela PAB. Vide um dos cantos costumeiros das celebrações inculturadas:

Hino de Glória

Glória ê, ê, Glória ê, povo negro dá Glória, ao Senhor, Glória ê!(Bis)

1. Glória Olorum, o criador, Glória Oxalá, Libertador, Glória ao Espírito. Que abriu o caminho que nos confirmou.

2. Pela ressurreição, daí Glória ê! Pela compaixão, daí Glória ê! Pela inculturação, daí Glória ê!

3. Pela comunidade, daí Glória ê! Pela irmandade, daí Glória ê! Pela liberdade, daí Glória ê!

4. Pela natureza, daí Glória ê! Pela alegria, daí Glória ê! Pela alegria, daí Glória ê! Pela utopia, daí Glória ê!

A religião de matriz africana Candomblé, é uma das diversas faces da religiosidade afro-brasileira, como já fora mencionado e o Padre Jurandyr, faz suas ressalvas em relação sua grandiosidade para a contextualização das ações 
concretas da Pastoral Afro-brasileira, que enfrentam desafios. Sinalizando que ela não é uma religião avulsa, que ela dispõe assim como as diversas religiões de subsídios para seus cultos.

"Candomblé tem suas tradições, seus livros, cultos, sacerdotes e sacerdotais. Então, é uma organização inclusive tem um instituto de teologia do Candomblé. Portanto, estamos nesse trabalho (...). Além disso, há o aspecto da dupla pertença. Porque até hoje essas religiões de matrizes africana não são aceitas e são perseguidas; hoje ainda algumas Igrejas perseguem essas religiões (...) O próprio Papa já disse que todas as religiões são boas, salvam".

Mas, a Pastoral Afro-brasileira, não desfruta apenas de dificuldades e desafios, a mesma, dispõe também de conquistas. E tendo como marco principal a Campanha da Fraternidade de 1988, a Pastoral Afro-brasileira completa 30 anos de militância e responsabilidade social. "Nestes 30 anos de pastoral Afrobrasileira fomos conquistando com a nossa metodologia participativa não só as pessoas, mas os grupos, dioceses e comunidades" (Padre Jurandyr)

A partir desse trabalho com as dioceses e comunidades locais, que as perspectivas em relação as demandas da Pastoral Afro-brasileira, foram florescendo e centralizando de acordo com as questões evidenciadas pela população negra. Além de permitir a melhor compreensão do racismo institucional existente em todos os âmbitos sociais.

Uma das conquistas mais importantes sinalizadas pelo Padre Jurandyr, foi a compreensão dos membros das PAB e dos participantes das ações articuladoras contra o racismo, de como funciona o sistema que exclui os grupos subordinados racialmente. Percebendo que o racismo é a alavanca utilizada para a exclusão dos grupos denominados diferentes dos grupos dominantes.

"Trata-se da forma estratégica como o racismo garante a apropriação dos resultados positivos da produção de riquezas pelos segmentos raciais privilegiados na sociedade, ao mesmo tempo em que ajuda a manter a fragmentação da distribuição destes resultados no seu interior".

Porém, Padre Jurandyr atenta para uma das maiores conquistas da Pastoral Afro-brasileira, que é o instrumento que norteia os líderes leigos e leigas articuladores da PAB, denominado como Cartilha do Documento da Pastoral Afro-brasileira, o mais importante subsídio ligado a Pastoral. Após esse norteador das ações da PAB, foram instituídas outros sobre as demandas emergentes da população negra, com o propósito também de criar novos grupos nas dioceses, paróquias e nas comunidades locais, que visassem a questão racial. 
Como a maioria dos espaços dispõe de opiniões e ações divergentes, Frei Tata, sinaliza como conquistas significantes obtidas através da articulação religiosa e social da Pastoral Afro-brasileira, a organização da auto imagem do negro. Assim como, novos espaços de militância, principalmente religioso, como as Irmandades, que fazem parte da vida do negro desde o período em que eles eram escravizados, conforme relato pelo mesmo a seguir.

Na minha opinião foram a reorganização da auto imagem de sermos negros e negras na Igreja e na sociedade. Os espaços e momentos celebrativos; a redescoberta das irmandades Negras como: a Irmandade de N. Sra. Do Rosário e S.Benedito centenária. Valorização dos Santos e Santas Negras (S. Benedito, Santa Efigênia...).

É importante ressaltar a importância que as Irmandades ocupam na história da população afro, visto que, esses foram espaços de organização dos negros durante o período da escravidão e que até hoje são lugares de referência religiosa, por evidenciar a identidade do negro. As Irmandades eram bem organizadas e embelezadas pelos negros, para que não devessem nada as Igrejas dos brancos.

Muitas das residências hoje em dia, reservam lugares sagrados para colocar suas imagens, como por exemplo, de Nossa Senhora do Rosário, que é a representação de Nossa Senhora identificada pelos religiosos católicos, como a grande mãe. A imagem do Preto Velho, também é bastante encontrada na casa de negros religiosos de religião de matriz africana, por representar a ancestralidade desse povo e a tão importante mãe-África. Pois, através dessas imagens é mantida a presença do sagrado que se encontra presente nas celebrações afro.

"Realizavam suas festas com todo brilho e esplendor e conseguiam fazê-las mais animadas e mais frequentadas que as de outras Irmandades e mesmo da Matriz dos arraiais e das cidades. Uma herança importante desta ligação com a Igreja e ao mesmo tempo de preservação de tradição africana encontra-se nas corporações de negros congadeiros existentes até hoje". (Texto base da Campanha da Fraternidade de 1988, p. 53)

As conquistas identificadas pelos líderes religiosos referente a Pastoral Afro-brasileira permeiam também criação e a execução de Congressos, Encontros temáticos, Secretarias, Grupos de discussões, Curso de formação, que não abrange apenas âmbito religioso. Pelo contrário, Frei Tata, sinaliza que socialmente as conquistas da PAB envolvem "A estética negra, o empreendedorismo negro, os Pré Vestibulares e cota"!

A Pastoral Afro-brasileira é um agente social, que intervém no seio da Igreja Católica, por isso, cabe salientar a importância das suas conquistas em 
prol da igualdade racial. Assim como, apontar os desafios que a Pastoral enfrenta através da militância de seus agentes articuladores, para que, possam se fortalecer em seus espaços de luta e principalmente, obter argumentos, para dialogar com os grupos dominantes, que constantemente tentam desmobilizar toda a articulação e trajetória dos movimentos sociais que prezam pela igualdade racial.

\section{2}

\section{A análise dos membros leigos sobre a importância da Pastoral Afro- brasileira}

Para analisar quais são os protagonistas leigos da Igreja Católica, que atuam nas articulações da Pastoral Afro-brasileira, é cabível entender o significado do que é ser leigo dentro da Igreja e qual o seu papel. Pois, a participação do leigo dentro da instituição é de suam importância para o andamento das ações concretas que a Igreja desenvolve principalmente o trabalho, conforme desenvolve a PAB.

O leigo não é apenas um participante das celebrações, pelo contrário, o cristão leigo é tido como parte da Igreja, sendo visto até, como parte da hierarquia da Igreja Católica. O leigo atua na realidade do tempo e não só nas demandas da comunidade eclesial, o que cabe a eles o papel de Corpo Místico de Cristo, ou seja, pertencentes da estrutura da Igreja. (Alcides Andreatta, 2009)

Essa denominação faz com que o cristão leigo, seja um membro pleno e efetivo no alicerce da Igreja Católica, não sendo somente um membro sem total pertença ou de representatividade inferior. Tendo uma maravilhosa missão e natureza espiritual, carregando também grande responsabilidade na sua vida religiosa, por servir de maneira legitima seu encargo religioso.

"Como frutos da "flor de inesperada primavera", o Concílio nos ofereceu diretrizes teóricas e práticas sobre o significado positivo do cristão leigo, superando interpretações que o considerem como cristão de segunda categoria dentro e fora da Igreja. Trata-se, agora, de continuar buscando as considerações e os meios para que essas diretrizes sejam praticadas em toda a sua profundidade e extensão". (CNBB 105, 2016, p. 24)

Um dos grandes motivos da Igreja Católica consumar cristãos leigos é a escassez da hierarquia da Igreja, como os padres, nos arredores das Paróquias, em conjunto coma dificuldade exposta muita das vezes pela falta de acesso ou crime organizado em ocupar alguns espaços e a grande demanda de fiéis para 
poucos sacerdotes. Essas sinalizações são os principais fatores que chamam os leigos para uma maior participação na vida eclesial.

Nessa linha de exposição sobre o papel do leigo, cabe ao mesmo fazer com que a Igreja "aconteça", conforme sinaliza o Documento 105 da CNBB, os denominando como "protagonistas da transformação social". Cabendo, portanto, uma maior valorização dos leigos, visto também, que um dos seus papéis é auxiliar o clero onde ele não consegue chegar, onde ele não consegue intervir, com isso, os leigos podem ser chamados pela Igreja de "auxiliares do clero".

Percebe-se então, que chamar os protagonistas da Pastoral Afro-brasileira, que são os coordenadores e os membros de leigo é pertinente, por desenvolver as funções que o leigo cristão desenvolve. Os participantes da PAB são imbuídos dessas responsabilidades dentro e fora da Igreja, por serem militantes de uma causa que afeta de forma latente toda a sociedade, embora seja velada.

"Na exortação Apostólica Evangelii Gaudium (n.20 - 24), o Papa Francisco lança um vigoroso chamado para que todo o povo de Deus saia para evangelizar. Toda a Igreja é convidada a sair agora para o encontro com Cristo vivo e com os irmãos em um mundo que clama por melhores condições de vida". (CNBB 105, 2016, p. 26)

Feitas as considerações que permite o reconhecimento de quem é o leigo dentro da estrutura hierárquica da Igreja Católica, cabe nesse momento, identificar quem são os protagonistas da Pastoral Afro-brasileira e em seguida analisar quais são suas percepções em relação à articulação e a atuação de cada entrevistado.

E para entender de forma mais consistente a gênese e a movimentação da $\mathrm{PAB}$, foram visitados os lugares de articulação, onde os membros da Pastoral desenvolvem suas ações concretas no Rio de Janeiro. A escolha pelo território empírico foi pela facilidade de acesso da pesquisadora e pela forte presença dos cristãos e militantes envolvidos com a Pastoral Afro-brasileira da arquidiocese do Rio de Janeiro estão presentes.

A aproximação e escolha pelas líderes leigas ocorreu devido à vivência que tive com os membros e participação nas atividades da Pastoral Afrobrasileira da arquidiocese do Rio de Janeiro. Principalmente pela trajetória de militância que Anazir Maria de Oliveira, conhecida como Dona Zica, coordenadora da Pastoral Afro-brasileira da Paróquia Menino Jesus de Praga, localiza na comunidade Vila Aliança no bairro de Bangu, Zona Oeste do Rio de Janeiro e a Cecília Costa, referendada na pesquisa como Senhora Cecília, 
coordenadora da Pastoral Afro-brasileira da Paróquia São Lourenço no bairro de Bangu, Zona Oeste do Rio de Janeiro, desenvolvem ao longo de suas vidas.

A Pastoral Afro-brasileira desenvolve grande importância na vida dessas líderes leigas, que denominam a PAB como um dos grandes desafios da sua vida, de acordo com a consideração de Dona Zica:

“(...), a Pastoral Afro pra mim é um grande desafio na minha vida. Por quê? $\mathrm{Na}$ minha origem de mulher negra, ex-empregada doméstica, moradora de favela, não tem nada de comunidade é favela mesmo, moradora de favela. Então, a Pastoral Afro é um desafio na minha vida. Eu vejo hoje uma das minhas lutas com as mulheres negras, a identidade das mulheres negras(...)"

Essa colocação da Dona Zica, corrobora para atentar a responsabilidade social que PAB desenvolve, sendo colaborativa para a construção da identidade dos negros, que também é estruturada através da interação social. Considerando esse processo de interação, mais amplo para potencializar ações concretas que tem como intuito intervir na construção da identidade do negro.

"E a identidade? Como ela pode ser vista? Jacques d'ADESKY (2001: 76) destaca que a identidade, para se constituir como realidade, pressupõe uma interação. A ideia que um indivíduo faz de si mesmo, de seu "eu", é intermediada pelo reconhecimento obtido dos outros, em decorrência de sua ação". (Gomes, 2003, p. 02)

A Senhora Cecília, quando perguntada qual a importância da Pastoral Afro em sua vida, a mesma foi categórica e fez uma comparação decorrente da fala de uma fala que ela ouviu em um encontro litúrgico. Cecília comparou o céu e o inferno, analisando que ambos não são lugares físicos, mas que o céu está perto de Deus, porém, deixou claro que não tinha uma opinião formada sobre essa comparação, mas atrelou a PAB ao céu e fez sua consideração.

"É o céu para quem? Pra quem luta por uma vida melhor, por um mundo onde as pessoas independentes de ser negro, indiano, ser islâmico, que as pessoas sejam reconhecidas e respeitadas. Então, eu acho que o céu é isso. Que é pra gente que está junto nessa luta, às vezes a gente fica um pouco triste porque pensa que não avançou, mas, como é bom parar com calma para refletir sobre isso".

É perceptível nas colocações de Dona Zica e da Senhora Cecília, o lugar de destaque que a Pastoral Afro-brasileira exerce na vida dessas protagonistas leigas. Assim como é notório em suas falas, que nessa "caminhada" o cuidado com o outro, em especial com a população negra é imprescindível, seguindo a missão do leigo que é de agente da transformação.

"O leigo deixa de ser agente de transformação da sociedade no sentido de uma verdadeira evangelização libertadora nos vários espaços da vida social, da política, da economia, da educação, dos meios de comunicação. Assim favorece, 
como agente do sistema dominante, a reprodução das estruturas injustas opostas aos princípios evangélicos". (Andreatta, 2009, p. 09)

Dona Zica, reconhece a importância da Pastoral Afro-brasileira para a questão social, porém, não deixa de atentar para a dificuldade que o seu exercício emana "Muitas das vezes, você encontra dificuldade, mas, nada acontece através do medo. O que sustenta a nossa fé hoje é uma fé efetiva, a outra parte é sacrifício e esperança". Essa declaração expressa de forma sucinta à história do negro, que é marcada por sacrifícios e não se resume na exploração e desgaste físico. Envolve o sacrifício de ter visto como mercadoria, como "raça" inferior, como desprovidos de beleza e inteligência, e principalmente o sacrifício de ter seus laços familiares fragilizados e deflagrados.

Ressalvo o sacrifício da degradação da familiar, por entender que a família é um dos pilares da construção da identidade, conforme aponta Nilma Lino (2011), contemplado também por considerações da Senhora Cecília, em relação à importância da Pastoral Afro-brasileira na sua família. "E assim, a pastoral pra mim, pessoalmente tem uma importância muito grande, por conta dessa influência na vida religiosa dos meus filhos".

A família é aparentemente um ponto em comum entre alguns dos núcleos da PAB que pude visitar. Durante o contato com os membros da Pastoral Afrobrasileira Achiropita, a vivência e a condução da família em relação aos mais novos, foi bastante mencionado. A Senhora M, membro da PAB Achiropita, relatou que costuma dialogar com seus filhos sobre a condição do negro em relação ao período que o escravizou, enfatizando que a população negra, não é e não foi culpada por sofrer essa prática de exploração.

Nas articulações da Pastoral Afro-brasileira, que pude acompanhar, observei que há um baixo número de jovens atuantes e que quase todos os que participam, são por influência da família. Essa estatística causa grande preocupação nos participantes atuais da PAB, visto que, o futuro da Pastoral depende da articulação da nova geração. Mas, conforme uma das declarações da Dona Zica, que ressalva que "Nada acontece através do medo", a Pastoral Afro segue se organizando, se movimentando e levando a conscientização negra dentro da Igreja e ocupando espaços de militância junto com movimentos sociais, não se antecipando em sofrer com o futuro da Pastoral. 


\title{
3.2.1
}

\section{O surgimento da Pastoral Afro-brasileira através do olhar dos leigos}

O ano específico que a ocorreu o surgimento da Pastoral Afro-brasileira ainda gera controvérsias, conforme fora mencionado, porém, para os articuladores envolvidos com a PAB entrevistados, o marco inicial foi a Campanha da Fraternidade de 1988. Embora, eles reconheçam que antes da CF de 88, tiveram na Igreja Católica movimentações advindas de grupos envolvidos com a questão racial dentro da Igreja, conforme analisa Dona Cecília.

"Eu sinceramente tenho uma certa dificuldade para falar sobre isso. Eles tinham um movimento, antes dos 100 anos da abolição já existia um movimento de padres, bispos e negros leigos dentro da Igreja Católica para que essas coisas fossem acontecer. Mas, efetivamente a pastoral afro começou a fazer um trabalho a partir da campanha da Fraternidade de 88".

A maioria dos membros atuantes da Pastoral Afro-brasileira, de diversos núcleos do Brasil, considera que Padre Toninho, sacerdote da Igreja Nossa Senhora da Achiropita, foi o patriarca da PAB. Conforme relatos da Senhora $\mathrm{M}^{17}$, Padre Toninho, chamou a Tia Jenny ${ }^{18}$, que iniciou a articulação junto com ele para realizarem uma Missa incultura, convidando os paroquianos para participar também. E logo após essa movimentação, foi realizada a Campanha da Fraternidade de 88 "Ouvi o clamor deste povo!".

\begin{abstract}
"Segundo Cida Godoy, o Grupo da Amizade foi precursor da Pastoral Afro na Igreja N. Senhora Achiropita. Esse grupo foi fundado na paróquia em 1986, no mesmo período em que o padre Toninho era Reitor da Faculdade de Teologia N. Senhora da Assunção, e lá criou outro grupo (Grupo Atabaque) para discutir a presença do negro na teologia e Igreja Católica". (Oliveira, 2011, p. 105)
\end{abstract}

Mesmo que Padre Toninho seja considerado o patriarca da Pastoral afro no Brasil, a Campanha da Fraternidade de 88 é o principal marco de surgimento da $\mathrm{PAB}$, pois foi a parti dela que o interesse sobre os problemas dos negros, ficaram mais latentes dentro da Igreja Católica. Dona Zica, que é considerada entre os membros da Pastoral Afro do Rio de Janeiro, pontua a importância da

\footnotetext{
${ }^{17}$ Senhora M: Membro pertencente da Pastoral Afro-brasileira Achiropita

${ }^{18}$ Tia Jenny: Jenny Teixeira Francisco, ou Tia Jenny, como é carinhosamente conhecida, foi a primeira pessoa que o Padre Toninho convidou para participar de uma nova Pastoral que ele iria iniciar
} 
Campanha da Fraternidade de 88 para os negros e pontua a não aceitação do tema na diocese do RJ.

"E foi uma campanha que deveria ter dado frutos igual a Campanha do menor. Campanha do menor deu fruto, que foi criado a pastoral do menor e que foi de visibilidade mundial. Pouco se falou da Campanha (88) aqui no RJ".

A Pastoral do Menor deu início na cidade de São Paulo em 1977 segundo a CNBB (2016) e só após 10 anos ocorreu a Campanha da Fraternidade referida ao menor. O tema da CF era "Fraternidade e o Menor", com o lema "Quem acolhe o Menor a Mim acolhe", refletindo novamente as considerações das Conferências de Medellín e Puebla, que centralizava o olhar da Igreja Católica, para os mais pobres e excluídos, socialmente.

Diferente da Campanha da Fraternidade de 88, que levantava as questões da população negra, a Campanha da Fraternidade de 87 , que tratava as mazelas dos menores infratores, ganhou visibilidade em todo o território nacional. A Pastoral do Menor, assim como a Pastoral Afro-brasileira, desenvolve sua responsabilidade social, atuando através de ações sociais e com o Conselho Nacional dos Direitos da Criança e do Adolescente (Conanda), de acordo com a CNBB (2016).

Conforme salientado por Dona Zica, a Campanha da Fraternidade de 88, não obteve êxito no Estado do Rio de Janeiro, porém, não desmobilizou a militância dos cristãos negros, envolvidos com a questão racial dentro da Igreja Católica e no âmbito social. Rosenilto Oliveira (2011) apontou à dificuldade de instaurar a referida CF no RJ, com o propósito de invisibilizar as mazelas expostas pelos negros dentro da Igreja. Senhora Cecília, relata que no RJ a voz dos negros foi calada pela a iniciativa do Dom Eugênio, que mudou até mesmo o tema da Campanha.

"Eu não lembro o tema, mas, eu sei que Dom Eugênio achou que o tema era um absurdo. Você está falando de preto por quê? Mas, é isso. Porque tinha um montão de gente necessitado, um montão de gente com problemas né. Como as pessoas falam, porque que vocês vão ficar falando, conforme já falaram para mim na minha paróquia. Porque que vocês vão falar de preto, com tanta gente precisando de coisas? Então, eu acho que a discussão tinha que ser mais aprofundada. Dom Eugênio achou que a gente não poderia estar falando. A campanha foi uma campanha nacional que no RJ não existiu".

Com isso, observa-se o quão grande é a dificuldade que os membros dos núcleos da Pastoral Afro-brasileira enfrentam, não só no Rio de Janeiro, mas em todo o âmbito nacional. Porém, a Senhora Cecília descreve como se torna pesado militar em prol da igualdade racial dentro da Igreja Católica, enfatizando 
sua cidade, que é o Rio de Janeiro, atentando para a dificuldade que ainda existe nessa diocese, em dialogar sobre a questão racial. E essa é uma característica ainda existente, mesmo passado um grande período, essa dificuldade ainda é latente, ou seja, não ocorreu transformação referente a visibilidade que envolve a questão racial dentro da Igreja Católica.

E essa dificuldade é externada, também através dos relatos que refletem o início da criação de cada núcleo da Pastoral Afro-brasileira e um dos maiores exemplos desses obstáculos, provém do relato de membros da Igreja Nossa Senhora da Achiropita, que tem como patrimônio da Paróquia, a Pastoral Afro. A Senhora M, ao dialogar sobre a construção da PAB na Achiropita, sinalizou um dos primeiros movimentos do patriarca Padre Toninho que foi a criação do Grupo da Amizade que foi antes de 1988.

O Grupo visava dialogar sobre a negritude e tinha o propósito de realizar Missas inculturadas, com isso, Padre Toninho, contou com a ajuda de Tia Jenny, conforme já mencionado ao longo da pesquisa. Tia Jenny assim como Padre Toninho, são tidos como símbolos de resistência e sabedoria por evidencia a negritude, segundo membros da PAB Achiropita. E exaltando a negritude, que esses ícones da Pastoral Afro da Achiropita, organizaram as primeiras Missas inculturadas, mesmo sendo impedido pelos membros da lgreja de realizá-las, mas, eles não esmoreceram e realizaram a celebração.

Os núcleos da Pastoral Afro-brasileira, que tive contato, também relataram suas dificuldades em criar a PAB em suas paróquias, principalmente pela resistência dos paroquianos em não enxergar que a lgreja católica, ainda hoje é uma instituição imbuída de racismo e preconceito. Dona Zica e a Senhora Cecília, iniciaram na Pastoral praticamente juntas, e ressaltaram que já haviam conhecimento e um sobre diversos movimentos envolvidos com a questão racial. Essas protagonistas leigas da PAB entrevistas, são católicas desde muito novas, conforme elas relataram que vieram de família católica, mas só tiveram conhecimento da Pastoral Afro-brasileira tardiamente. A Senhora Cecília relata que sua atuação na Pastoral iniciou através de um convite para fotografar uma Missa inculturada, presidida por Frei Tata.

\footnotetext{
"Ai eu fui, quando chegamos lá, era o Frei Tata que estava celebrando com o pessoal de São João de Meriti e era uma Missa inculturada. E a gente descobriu que celebrava Missa ali, Missa de Zumbi e Missa de São Jorge. Me parece que foi a primeira Missa que a gente foi, foi a Missa de São Jorge. Ai a gente começou a ter contato com São João de Meriti e com o Frei Tata. Ai a gente resolveu ir na Romaria, que anunciaram a Romaria lá em Aparecida".
} 
Senhora Cecília, em um dos momentos da entrevista relatou que a Pastoral Afro-brasileira, tem um papel importante na formação dos seus filhos, que também cresceram frequentando a Igreja Católica. Esse apontamento é caracteriza por Nilma Lino (2011), como fundamental na criação do indivíduo, pois, a autora caracteriza a família como um dos principais componentes para a construção da militância negra. Visto que, a família durante toda a história da população negra, sempre sofreu com toda a prática de exploração do período escravocrata, pois, era deflagrada devido às condições de trabalho e venda dos negros escravizados.

Durante o diálogo, a Senhora Cecília ressaltou que nos primeiros contatos com a Pastoral Afro-brasileira, seus filhos que as atividades exercidas pela Pastoral não eram da Igreja Católica "E e L não queriam ir, que achavam que não era da Igreja Católica. Enfim, quando a gente chegou lá foi à conversão da família inteira e converteu a Pastoral afro". A conversão fez com a família assumisse o compromisso de todo primeiro domingo participar das celebrações inculturada e a iniciar um trabalho de criação da PAB em sua Paróquia.

E para que desse início na construção da Pastoral Afro-brasileira, a Senhora Cecília, fez seu primeiro convite para a Dona Zica, que segundo ela, prontamente aceitou e também começou a participar das Missas em São João de Meriti, "Ela que ajudava a organizar a Missa aqui, né, ela era assessora do Carlos Santana, mas era quem promovia as festas e ela começou a ajudar a organizar as Missas aqui".

As ações da Pastoral Afro-brasileiras, como encontros, curso de formação e Congressos, além de evangelizar, sinaliza a responsabilidade social que a PAB desenvolve e torna-se uma ferramenta de apresentação dos núcleos, além de fortalecer o elo entre os grupos existentes. E foi dessa forma, através do já mencionado CONENC (Congresso Nacional das Entidades Negras Católicas), que a Senhora Cecília e Dona Zica, tiveram contato com outros coordenadores de núcleos da Pastoral Afro-brasileira do Rio de Janeiro e de outros Estados.

"CONEC de 2012 e lá a gente foi conversando e soube que a Adriana e o pessoal de Santa Cruz já tinham tido contato com a Pastoral Afro, através do curso do Rio. Que no curso do Rio fizeram oficina sobre a Pastoral Afro e tal. Então, a Adriana já tava. Santa Cruz já tava vindo com um trabalho anterior, ao nosso ingresso lá em São João lá em Santa Cruz, na CEBS Santa Veridiana. Ai nós viemos com a missão lá do CONENNC de organizar a Pastoral Afro nos diversos espaços. E ai a gente veio com o compromisso de organizar, essa era a missão do CONENC. Organizar a Pastoral Afro nos seus espaços" 
A formação dos grupos da Pastoral Afro-brasileira também era beneficiada por esses Encontros, pois, um fortalecia o outro para instituir um grupo. Cada participante saia dos encontros mais estimulados para criar PABs em suas paróquias. E foi dessa forma, que A Senhora Cecília saiu do CONENC de 2012, decidia a criar uma Pastora Afro-brasileira na sua paróquia e iniciar a militância cristã, visando à igualdade racial.

"Me parece que tinham poucos grupos organizados como Pastoral Afro e ai a gente veio com essa função. Ai nós fizemos uma reunião pós CONEC lá em São João ainda. Ai foi o pessoal de Santa Cruz, pessoal de Lucas, foi na época Niraldo ${ }^{19} \mathrm{e}$ Carlos Henrique ${ }^{20}$ também foi muito legal. E ai a gente começou a pensar em organizar a Pastoral Afro aqui".

Porém, a organização segundo Cecília, não foi suficiente para que a criação da Pastoral Afro-brasileira, pois, conforme deslinda Nilma Lino (2002), a história do negro é permeada de resistência e essa característica segue presente na vida da população negra até hoje, não diferindo da história da PAB. O mito da democracia racial é algo que está imbricado socialmente e é um dos fatores que mais contribuem para que o negro ainda sofra com ações negativas constantemente, os tornando ainda mais resistentes as demandas da questão racial.

"Paralelamente a toda uma sorte de situações de discriminação e da construção de uma representação social negativa sobre o "ser negro" no Brasil, nós, os negros, construímos uma história rica de reação e resistência, produzimos cultura e impregnamos o Brasil com a nossa estética, nossa visão de mundo, nossas crenças, nossa forma de fazer política e nossos valores". (GOMES, 2002, p. 10)

Os relatos referentes à construção da Pastoral Afro-brasileira na maioria dos grupos demonstram essa resistência que é parte do negro. Quando a Senhora Cecília, dissertou sobre a criação da PAB na sua Paróquia, a mesma sinalizou que os primeiros encontros da Pastoral, para articular as primeiras ações, aconteciam nas casas dos membros participantes e não na própria Igreja como habitualmente.

"Enquanto a gente não conseguia isso a gente se reunia nas casas para ver quais as ações, como a gente ia fazer e fomos amadurecendo a ideia e começamos a levantar esse questionamento aqui no Rio. Padre Jurandyr sempre com a gente né. Tentando conversar com o cardeal Dom Orani ${ }^{21 " .}$

\footnotetext{
${ }_{19}^{19}$ Niraldo - Padre simpatizante com a Pastoral Afro-brasileira.

${ }^{20}$ Carlos Henrique- Padre simpatizante com a Pastoral Afro-brasileira.

${ }^{21}$ Dom Orani Tempesta - arcebispo do Rio, foi nomeado cardeal pelo Papa Francisco em 2014.
} 
Os relatos que descrevem a trajetória de surgimento da Pastoral Afrobrasileira envolvem explícita e implicitamente todos os desafios que a população negra está exposta socialmente em seu cotidiano. Perpassando desde as questões de invisibilidade de suas demandas, desde a falta de interesse que a classe dominante não desenvolve em relação às mazelas que o negro emana em seu cotidiano, até suas conquistas, pois, a construção de uma Pastoral que atua em prol da igualdade racial, dentro de uma instituição até hoje conservadora como a Igreja Católica deve ser considerado uma vitória.

Essa conquista é fruto do posicionamento dos negros cristãos, que através da sua militância almeja sempre externar e lutar para que sua negritude seja evidenciada e respeitada perante a sociedade que vive o mito da democracia racial, mas, que explicita constantes ações preconceituosas, que relativizam o racismo. Evidenciando ainda mais o quanto a sociedade é racista e classista, corroborando também, para que o racismo continue sendo institucional, reproduzindo ações opressoras a população negra nos diversos espaços.

Canto das celebrações inculturadas que remetem as Vitórias dos negros:

Foi Olorum que mandou celebrar nossa história.

E festejar as vitórias, conquistadas por quem lutando tombou.

Povo negro trazido de longe, escravo, a queriza gerou.

Não aceitou a chibata. Quilombo liberdade, de uma raça com valor! Foi Olorum!

\section{2 .2}

\section{A análise sobre as atividades concretas desenvolvidas pela Pastoral Afro-brasileira}

Elucidar sobre a identidade negra é o principal caminho para entender toda a articulação da Pastoral Afro-brasileira, que desenvolve desde o seu surgimento ações concretas em prol da questão racial. Pois, a identidade é a forma como cada "povo" se enxerga, de acordo com a contextualização de Nilma Lino (2002).

E com base na contextualização já exposta nessa pesquisa, a identidade é uma construção social, que provém da história de cada "povo", ou seja, ela é fruto de uma herança, que no caso da população negra é permeada de racismo, estigmatização, discriminação e preconceito. E decorrente dessas ações negativas, a Igreja Católica, através do subsídio da Campanha da Fraternidade de 88 , assinala o quão importante é reconhecer, que o negro ainda desfruta 
dessas ações negativas, que o impede de ser tratado de forma igual na sociedade.

"Trata-se, isto sim, de reconhecer, à luz da fé, que os traços deste passado permanecem ainda hoje e não contrários à dignidade do homem, à fraternidade $\mathrm{e}$ à justiça. A consciência e denúncia dessa situação são indispensáveis para a conversão e consequente mudança efetiva de nossas atitudes e para a necessária transformação social". (Texto base da Campanha da Fraternidade de 1988, p. 33)

Não constrói identidade através do isolamento, sem troca, sem o diálogo, a relação social, ou seja, a identidade é estabelecida com o outro, com experiências. E desta forma a identidade negra foi construída, através da densidade dos conflitos, da evidenciação cultural e religiosa, por isso, torna-se pertinente que os próprios negros disseminem sua identidade, a fim de externa também sua rica contribuição na construção do país.

Sendo assim, a Pastoral Afro-brasileira, deve ser considerado um grande agente interventor da disseminação da identidade afro no Brasil. Por exercer um importante papel de responsabilidade social, mediando diretamente o diálogo sobre a conscientização da identidade negra na comunidade local, através das ações concretas realizadas com os paroquianos, com o propósito de evidenciar cultura negra e agir na desigualdade racial dentro e fora da Igreja Católica.

Dona Zica, salienta, portanto, que nem todos os negros envolvidos com a Pastoral Afro-brasileira da sua paróquia, tem o conhecimento de que a exaltação da identidade negra é um grande instrumento de luta contra o racismo. A mesma ressalta na entrevista qual a sua forma de atuação principalmente com os jovens da paróquia.

\footnotetext{
"Usam como estética, como moda, mas tem que ter o compromisso racial. Essa é uma grande importância. Trabalhar essas meninas para estar intuindo, para intuindo essas meninas na pastoral. Para que elas também tenham essa visibilidade, que ser negro é bonito, que ser negro é bom, que ser negro é defender uma raça".
}

É importante destacar, com base nas considerações expostas por Dona Zica, que a juventude desenvolve um importante papel no seio da lgreja Católica, que os denominam como seres renovadores de experiências e evangelização. Um dos documentos da CNBB que faz menção a esse protagonismo dos jovens, mencionando a grandiosidade que é a missão de evangelizador essa fonte de riqueza que é a juventude, os mostrando o quanto seu papel é representa frente aos desafios de toda a transformação histórica que a sociedade vive. 
"A juventude mora no coração da Igreja e é fonte de renovação da sociedade. Os jovens de todos os tempos e lugares buscam a felicidade. A Igreja continua olhando com amor para os jovens, mostrando-lhes o verdadeiro Mestre Caminho, Verdade e Vida - que os convida a viver com ele". (CNBB, 2010, p. 09)

Por essas questões, que Dona Zica priorizou na entrevista, sua atuação com as adolescentes que visivelmente estão preocupadas com a moda, com a estética e não com a exaltação da identidade afro, conforme ela assinala "Uma das grandes importâncias é querer aproximar essas meninas, fazer essas meninas a tomarem consciência de qual seu papel enquanto negritude, enquanto compromisso e ter uma visão de que a transformação tem que partir de nós".

E assim como Dona Zica destacou a importância da transformação, para os jovens negros, Cecília, também pontua a questão de transformar esses jovens, pois, a mesma é professora na Rede Pública de Ensino do Rio de Janeiro. Sua turma é composta majoritariamente por meninos negros, moradores de favela e que constante são perseguidos por policiais armados. Então, Cecília diálogo com seus alunos sobre a questão racial constantemente, apontando a importância da transformação.

“(...) é a questão da transformação, conscientizar, de transformar, a gente pode transformar. Eu não tenho que ser aquilo que as pessoas estão dizendo que eu sou. Tenho que mostrar que eu sou diferente ou posso me transformar. É uma coisa que eu estou sempre colocando para os meus alunos. Vocês podem ser diferentes".

Esses relatos, só transparecem o quanto a cidadania, a responsabilidade social dos envolvidos com a Pastoral Afro-brasileira se tona importante na articulação da Pastoral, pois, diálogo sobre negritude no Brasil ainda enfrenta muita resistência. E essa é uma das grandes responsabilidades da PAB, juntamente com a luta pela conquista da cidadania para população. (Subsídio de Estudo e Formação para Agentes de Pastoral Afro, 2007)

Um dos caminhos para conquistar a cidadania dos negros, é o reconhecimento da identidade negra, visto que, a sociedade é desenvolvida sobre a perspectiva da população branca, que ainda hoje renega e desqualifica a cidadania dos negros, reduzindo muitas vezes, sua presença como meros reprodutores de força de trabalho. E é exatamente sobre a importância de refletir sobre a identidade negra, que Dona Zica pauta os encontros da Pastoral Afrobrasileira na sua paróquia, chamando os cristãos participantes da PAB a se permearem na cultura afro. 
"Descobrir identidade, ele vai lutar pelos direitos dele, por direito de igualdade. Ele mesmo vai perceber está discriminação sutil. Ele mesmo vai perceber o preconceito no olhar, numa palavra. Porque é sutil, né. Ele vai perceber. Mas, a partir do momento que ele descubra a identidade dele. E essas jovens são um grande compromisso para a gente".

A questão da hegemonia branca, da ideologia do branqueamento está intrínseca na sociedade e é algo que não causa indisposição na população branca em relação às mazelas apresentadas pelos negros, que estão constantemente em situação de desvantagem socialmente, confirmando a supremacia branca, conforme relata Florestan Fernande (2008). O monopólio da "raça branca" está imbuído até mesmo na Igreja Católica, que é eurocêntrica.

Os convites e explicações em relação a atuação da Pastoral Afrobrasileira, geralmente transparecem a supremacia da população branca, por achar que há necessidade de existir uma Pastoral, que atua contra as desigualdades que assolam os negros desde o período escravocrata. Os relatos da Dona Zica, exemplifica exatamente essa afirmativa da hegemonia, assim como, a importância de conscientizar os jovens negros da sua ancestralidade.

\begin{abstract}
"No meu grupo tem o $E^{22}$, que é branco né e ele fala sempre: Eu bato numa tecla que a gente só vai avançar quando trouxer a juventude, trabalhar a juventude. Esse também é um desafio para a Pastoral Afro. Aqui na paróquia já perguntaram porquê da pastoral. Porque então também vou criar a pastoral do branco. Eu respondi: Se vocês sentirem necessidade, criem. Então, vê como a discriminação é sutil. A gente na hora não rir".
\end{abstract}

Uma das dificuldades que os negros sofrem dentro da Igreja católica é o não pertencimento daquele espaço, por falta de participação em todas as dinâmicas das Missas e atividades religiosas, como celebrações dos Santos e coroações.

O religioso dos Direitos Humanos, Frei Davi Raimundo dos Santos (2014) militante também das causas da questão racial e que teve um importante papel no período do surgimento dos APNs, assinala em suas considerações que a Igreja Católica não se colocava disposta a aceitar as diversidades culturais existentes. Não se importando também com a religiosidade que a população negra exala o que atualmente não se difere muito, pois, em sua base a Igreja

\footnotetext{
${ }^{22}$ E - Membro da Pastoral Afro-brasileira da Paróquia Menino Jesus de Praga, localiza na comunidade Vila Aliança no bairro de Bangu, Zona Oeste do Rio de Janeiro, que se identifica etnicamente como branco.
} 
habitualmente não se coloca à disposição dessa diversidade, se mantendo minimamente ecumênica em sua estrutura religiosa.

Esses apontamentos foram constantemente expostos pelos negros cristãos e foi sinalizado no manual da Campanha da Fraternidade de 88 critérios que podem serusados para a supressão de atitudes negativas que discriminam os negros dentro da Igreja Católica, dificultando ainda mais o pertencimento dos negros nesse espaço. Essas situações sinalizadas foram relatadas pelas líderes leigas da $P A B$ na entrevista, levando a refletir o quanto a Igreja sempre foi discriminatória com o negro, conforme analisou Dona Zica.

“(...)sonhava cantar no coral e sempre que abria inscrições para novos cantores, eu era a primeira me apresentar para novos cantores. Eu era a primeira me apresentar, mas nunca me chamaram. E ainda tinha no mês de Maria, mês de maio, as coroações eram só aquelas meninas brancas, então nós meninas negras, todo mundo, a criançada da catequese buscava as meninas em casa para trazer para a Igreja, era procissão para coroar Nossa Senhora. Mas, eu me lembro de nunca ter coroado nenhuma menina negra e isso foi me torturando a memória".

As experiências da Senhora Cecília não diverge muito das experiências vividas por Dona Zica, pois, ambas por influência da família, frequentam a Igreja Católica desde criança "Eu sempre fui de família, os avós católicos. Meu avô era liderança religiosa, minha avó também. Então, a gente vem de uma tradição mesmo católica". Corroborando para o entendimento de que a família é um instrumento fundamental para a conscientização da identidade do indivíduo.

Dona Zica e a Senhora Cecília, durante a entrevista, apontaram para algumas mudanças que tiveram nas paróquias em que fazem parte. Elas sinalizaram que após o surgimento da Pastoral Afro-brasileira houve transformações em relação à participação do negro nas celebrações e festas. Dona Zica, relata que seu posicionamento em prol da questão racial, influenciado pelas ações concretas executadas pela PAB, mesmo encontrando desafios, surtiram efeito e assinala a mudança que tiveram, quanto ao seu questionamento em relação a não participação de crianças na festa de Coroação de Nossa Senhora.

\footnotetext{
"Depois de adulta aqui na Igreja, avó de neto e tudo, eu questionei isso, questionava sempre, mas o questionamento nesse momento foi muito mais forte. Porque essa discriminação? Nós tínhamos famílias portuguesas, as filhas das portuguesas coroando e o que fizeram, depois do meu questionamento? No mês de maio seguinte convidaram a minha neta para coroar Nossa Senhora. Eu digo, não é isso, eu não questionei para minha neta coroar, eu questionei para abrir espaço para crianças da catequese. Negras tem o mesmo direito, entende? Então,
} 
você vê que é complexo, não se percebe é sutil. Se você não gritar, a sua voz não é ouvida".

A vivência da Senhora Cecília, também é permeada de episódios de discriminação dentro da Igreja Católica, expressando com mais afinco o quanto a Igreja mesmo depois do período em que os negros foram escravizados ainda externando racismo. E mesmo a instituição tendo entendimento de todas as dificuldades vividas pela população negra socialmente, ela ainda seguia/segue reproduzindo ações preconceituosa e racista em suas atividades, conforme a Senhora Cecília relata.

“(...)porque eu era de uma família religiosa e costumava rezar o terço nessa casa, na gruta. As crianças não participavam porque não tinham o hábito de rezar em casa, mas, quando chegava o dia de coroar Nossa Senhora, tinham as pessoas branquinhas para coroar Nossa Senhora e a gente nunca teve a oportunidade disso, eu nunca tive a oportunidade nem de me vestir de anjinho, quem dirá de coroar Nossa Senhora".

Embora existam notórias mudanças em relação ao posicionamento da Igreja Católica, que são decorrentes da centralização do olhar da Igreja para a questão social, fruto do Concílio Vaticano II e das Conferências de Medellín em 1968 e de Puebla em 1979, que denunciavam a discriminação e o preconceito dentro da Igreja. Resultados que deixam mais latente a responsabilidade social da instituição, que é refletida principalmente nas ações concretas desenvolvidas pelo grupo das Pastorais Sociais, enfaticamente na Pastoral Afro-brasileira, que tem grande responsabilidade com a população negra.

"Olhando o momento atual da Igreja, principalmente nas últimas décadas, nota-se maior consciência sobre a realidade afro. Assuntos de interesse da população negra são discutidos e tornam-se prioridade pastorais em diversas dioceses e regionais. Em alguns casos, o apoio da Pastoral tem sido importante para que parcelas da população negra consigam seus objetivos, por exemplo, a titulação das terras de antigos Quilombos". (CNBB, 2008, p. 51)

Porém, cabe salientar que o fato da lgreja ter atentado para a não participação do negro nas atividades promovidas e os ter inserido em decorrência da militância dos negros cristãos, surtindo como cota racial para alguns membros da Pastoral Afro-brasileira, conforme atentou a Senhora Cecília "Eles mesmos falam, eu já ouvi falar: olha só, tem que colocar um pretinho aqui. Tipo tem que ter a cota. Não interessa se eles ainda não aprenderam, mas, as crianças pretinhas que estão lá na plateia, as pessoas negras, se sentirem 
incluídas". Mas, a mesma reconhece que o entendimento da questão racial, dos danos que ela causa no cotidiano dos negros, talvez não tenha sido alcançado.

"É o que eu falo para a $L^{23}$, não interessa que o cara que colocou, botou só para não ficar mal na fita, claro que a gente preferia que ele tivesse se convertido (entendesse sobre questão racial) já, mas, a criancinha pretinha que está lá sentadinha, fala: poxa tem alguém igual a mim ali. Ih, aquela moça preta que está lá, né. Lá eu acho isso muito bom. Claro que é a cota, mas, já é um caminho".

Dona Zica também entende que essas ações não são suficientes para que um dos objetivos da Pastoral Afro-brasileira, que é contribuir para a união de todas as "raças", em prol de uma melhor sociabilidade entre os "povos", seja alcançada, almejando também o não isolamento da população negra no espaço da Igreja Católica (CNBB, 2008). Porém, entende-se que essas atitudes que determinam a participação de pelo menos um negro nas atividades da paróquia, são imprescindíveis para continuar o trabalho da $P A B$, estimando reduzir as dificuldades que assolam os negros.

\begin{abstract}
"O menininho negro vai lá e faz ofertório. Mas, o que a gente precisa é trabalhar esse menininho negro que faz ofertório, faz a leitura, para ele descobrir a identidade dele enquanto negro. Porque senão, ele vai crescer e vai ser como as meninas que usam a imagem negra como estética. Esse menino tem que ser trabalho desde a catequese para isso. Eu achei assim interessante, a coroação dos meninos né. Eu achei muito bonitinho o menino (negro) da Irene, vestido de anjo. Eu digo, alguma coisa está mudando e também assim, eu acho que a gente tem que ser perseverante".
\end{abstract}

A estimativa dos membros da Pastoral Afro-brasileira é conscientizar a sociedade da importância que a população negra desenvolve na construção do país, assim como, evidenciar sua cultura, religião e costumes. Porém, para que a $\mathrm{PAB}$ alcance esse objetivo é necessário que os membros envolvidos com a Pastoral se articulem e realizem ações que visem e enfatizem a importância da cultura e identidade negra. Essa articulação que atualmente a PAB desenvolve é herança do período em que os negros eram escravizados, conforme suas práticas antigas realizadas nas Irmandades.

"As Irmandades, entre os negros, tinham um desempenho eminentemente pastoral. Seu escopo era reunir irmãos e as irmãs em comunidade para a oração e para conseguir recursos para se obter a alforria (libertação) dos que continuavam escravos. Caso a ação libertadora não chegasse há tempo, zelavam pelo funeral digno dos irmãos defuntos (Irmandades de N.Sra. da Boa Morte). (Pastoral Afro Achiropita, 2013, p.07)"

\footnotetext{
${ }^{23} \mathrm{~L}$ : É a filha da Senhora Cecília, que também faz parte da Pastoral Afro-brasileira.
} 
E essa herança é algo que perpetua entre a população negra, seja no âmbito religioso ou social. Tomando a Igreja Católica como referência e a Pastoral Afro-brasileira como contexto central, cabe com isso, ressaltar que as atividades promovidas pela PAB ocupam lugar de destaque na luta em prol da igualdade racial. Mas, é uma prática que já havia sendo desenvolvida através dos APNs, porém, com algumas ressalvas que diferenciam suas atuações com as ações concretas da PAB.

Ao visitar a Pastoral Afro-brasileira Achiropita, um dos membros, relatou que o patriarca da PAB, Padre Toninho, antes mesmo do surgimento da Pastoral, criou um grupo chamado Atabaque, que visava o diálogo sobre as demandas da questão racial, mas, alguns religiosos que faziam parte desse grupo, em determinado momento começaram a divergir nas ideias e se ausentaram dos encontros.

Os grupos de discussão, troca e articulação de ações concretas em prol da questão racial, tornaram-se mais presentes após o novo olhar da Igreja Católica para a questão social, centralizando suas ações nos mais pobres, nos negros e nos marginalizados. Grupos como os APNs continuaram a desenvolver estratégias para dialogar sobre as mazelas que atingem a população negra. $E$ assim também, a Pastoral Afro-brasileira seguiu com o compromisso de intervir na igualdade racial através reuniões, encontros, curso de formação e congressos.

Porém, cada núcleo da Pastoral Afro-brasileira tem sua maneira de conduzir seu grupo, seus encontros, sua dinâmica de intervenção, mas, atentei para o fato de que embora cada grupo exerça de forma diferenciada suas ações, a maioria dos núcleos, ainda dispõe de reuniões e cursos de formação. Dona Zica, relatou como funciona na Paróquia Menino Jesus de Praga, em que a mesma coordena o grupo da PAB.

(...) na paróquia de Menino Jesus de Praga, nós fizemos nosso calendário de termos quatro atividades em 2017. Dia internacional da mulher, buscando essas datas marcantes. Dia internacional da mulher. É mês da Bíblia e o curso de formação. No dia internacional da mulher, nós nos reunimos para falar das mulheres na Bíblia, as mulheres da Bíblia no antigo testamento, escolhemos quem? Rute e Ester, certo. (...)O outro foi o curso de formação, a semana de formação, ai nós vimos o que vai ser atraente, que a gente pode estar trazendo uma visão de que a pastoral, qual o papel da pastoral enquanto Igreja. Ai escolhemos para discutir o Documento 105 e o Documento de Aparecida.

A descrição das atividades que os núcleos da Pastoral Afro-brasileira desenvolvem, explicita ainda mais a responsabilidade social que a mesma 
exerce, pois, de acordo com seus coordenadores o convite para participar dessas atividades é estendido a todos, não só negros cristãos envolvidos ou não como a PAB. A própria Dona Zica, relatou que nesse haviam pessoas que são envolvidas com a Pastoral, mas que se sentiram a vontade para participar.

As atividades desenvolvidas pela Pastoral Afro-brasileira incluem estudo de documentos religiosos que elucidam sobre a importância de agir sobre as mazelas que excluem um determinado grupo socialmente, assim como a responsabilidade de ser um cristão em meio às transformações sociais, afirmativa essa relatada por Dona Zica.

"O outro foi o curso de formação, a semana de formação, ai nós vimos o que vai ser atraente, que a gente pode estar trazendo uma visão de que a pastoral, qual o papel da pastoral enquanto Igreja. Ai escolhemos para discutir o Documento $105 \mathrm{e}$ o Documento de Aparecida".

O Documento de número 105 da CNBB (2016) atenta para as responsabilidades de leigos e leigas cristãs dentro da Igreja Católica, refletindo sobre a sua postura nessa sociedade tão discriminatória, que exclui os denominados "diferentes". Fazendo menção a passagem bíblica que sinaliza que o cristão deve ser Sal da terra e Luz do mundo não só no seio da Igreja, mas também na sociedade em geral.

“(...) O dom do Espírito se efetiva na ação concreta de cada membro da comunidade, como explica o apóstolo Paulo. O critério da ação é a edificação da comunidade (1Cor 14,12). Em função do bem comum, a comunidade organiza-se no compromisso de cada membro e busca os meios de tornar mais operantes os dons recebidos do Espírito". (CNBB, 2016, p. 10)

Conforme fora mencionado, cada núcleo da PAB desenvolve suas atividades de acordo com as necessidades e disponibilidade do seu grupo Pastoral. A senhora Cecília mencionou como ocorre a dinâmica na Paróquia de São Lourenço no Bairro de Bangu em que a mesma coordena um dos núcleos da Pastoral Afro-brasileira do RJ, explicitando que embora ambas as coordenadoras iniciaram juntas a atuação na $\mathrm{PAB}$, as dinâmicas dos núcleos ocorrem de maneira diferente.

"E a agente lá na São Lourenço, o que a gente faz? A gente trabalha os temas (...) É aberto para a comunidade, só que o pessoal não vai e a gente faz a discussão dentro das nossas reuniões, as discussões são feitas dentro das nossas reuniões. A gente escolhe um tema. Por exemplo, no início de agosto, porque no outro não teve. A gente fez um trabalho sobre Santo Agostinho, Santo africano na base da Igreja". 
A Senhora Cecília sinalizou que não há curso de formação na PAB da sua Paróquia, mas assinala que "Então, a nossa formação é uma formação que é continuada, entendeu? É dentro do grupo é dentro de nós. A gente escolhe um tempo para fazer essas discussões. Entendeu? " Ela ressalta também, que com a falta de participação da comunidade nas atividades da PAB, formar outra liderança para continuar a articulação da Pastoral fica muito difícil, assim como na Paróquia Menino Jesus de Praga.

"É difícil você formar uma liderança para assumir, é difícil. É muito tempo. Hoje lá na São Lourenço e na Menino Jesus nós temos duas pessoas apontando como liderança. E a gente está rezando a Deus por elas. Lá na São Lourenço é a Odete. Odete levou dois anos namorando a pastoral, a gente tem três anos de pastoral. Hoje ela é uma pessoa assim, que toma bastante atitude, da palpite e sai. Então, a gente está rezando a Deus para que ela possa assumir".

Durante a pesquisa, tive contato mais efetivo com os núcleos da Pastoral Afro-brasileira do RJ, com isso, identifiquei que há uma grande interação entre os grupos do RJ e eles se articulam também com movimentos sociais. Visto que, muitos dos membros da PAB estão envolvidos em movimentos sociais, como por exemplo, Dona Zica, que é a matriarca do Sindicato das empregadas domésticas, por isso, a mesma sempre que há possibilidade, alinha as atividades do grupo da Pastoral Afro-brasileira, com atividades sociais em prol da questão social.

"Outra coisa também no social, no âmbito social, eu estou fazendo por exemplo através das domésticas em 2015 e 2016, organizamos junto com a pastoral das domésticas e do pré-vestibular o encontro com alunos de intercâmbio do Texas. Como pastoral Afro, esse ano também são três anos seguidos".

Após esse relato, Dona Zica também revelou que há uma interação da $\mathrm{PAB}$ com os movimentos sociais "A gente aqui na paróquia caminha muito junto com o pré-vestibular. Então, essas são as atividades dentro e fora da lgreja". Salientando, que o papel social da Pastoral não se restringe apenas no espaço da Igreja Católica, mesmo que a articulação seja com outro grupo da Pastoral Social, como acontece com a Pastoral de Favelas, que também exerce eminentemente sua responsabilidade social, intervindo nas mazelas expostas nas favelas locais.

No Rio de Janeiro os núcleos da Pastoral Afro-brasileira se unem para pensar articulações em conjunto, além das exercidas em sua Paróquia, conforme descreve a Senhora Cecília " $A$ pastoral é uma só, mas é diferenciado $o$ trabalho. Quando a gente fala da pastoral do $R J$, todo $R J$ arquidiocese, ai sim, a gente tem um trabalho". E todas têm liberdade para pesar e exercer suas 
atividades individuais, de acordo com Dona Zica "Cada grupo tem sua forma de trabalhar.São Sebastião trabalha da sua forma. Santa Veridiana trabalha da sua forma. Entendeu? Essa liberdade de cada grupo".

As líderes religiosas leigas, mencionam a importância do contato entre os núcleos da PAB, destacando a diferença de cada um dos grupos. Mas sinalizaram também, o quanto é rico a aproximação dos núcleos, a articulação das ações concretas que eles desenvolvem juntos e a realiza dos cursos de formação que acontece em torno de três vezes ao ano. Segundo a Senhora Cecília:

"O que acontece. A pastoral de Lucas, a pastoral de Cavalcanti, a pastoral de Jardim América, Santa Cruz, as duas de Bangu, nós somos diferentes. O engraçado é que a gente até falou isso lá na pastoral de São Lourenço, nós somos diferentes. Isso é muito rico, porque quando a gente tem reunião, quebra o maior pau, mas um acrescenta o outro. Um grupo acrescenta o outro. A pastoral é rica. A nossa pastoral, a pastoral do RJ ela é muito rica com isso. Que ela não é um grupo só, ela não é única. A diversidade enriquece".

E são das diversidades e desses encontros que acontecem mensalmente, conforme as líderes entrevistadas relataram que surgem o calendário anual da Pastoral Afro-brasileira do RJ, que inclui as atividades desenvolvida por cada PAB em sua Paróquia, os compromissos sociais em conjunto com os movimentos sociais e os importantes cursos de formação, de acordo com a consideração da Senhora Cecília.

\footnotetext{
"Mas, sem divergência não tem crescimento. Imagina todo mundo pensar a mesma coisa, vai ficar um montão de coisa fora. Às vezes a gente tem que ceder ao que o outro grupo lá falou, mesmo sem concordar, que o grupo falou, a gente tem que ceder. Depois que a gente cede que a gente vem perceber, caramba como foi bom ter cedido. Isso é uma verdade".
}

Desde o período em que o Padre Toninho começou a articular as ações concretas da Pastoral Afro-brasileira, que há os encontros e cursos de formação, que dialogam sobre a temática racial. E embora o início da PAB tenha sido após as Conferências que trouxeram visibilidade aos negros, o patriarca ainda enfrentou muita resistência na Paróquia Nossa Senhora Achiropita, para desenvolver suas ações em prol da conscientização racial.

"Em 1989, com a efetivação do Padre Toninho como pároco da Igreja Nossa Senhora Achiropita, o grupo Pastoral Negro começou a se tornar uma realidade. De início, as primeiras reuniões contavam, quando muito, com vinte pessoas. Hoje, os integrantes da Pastoral Afro ultrapassaram a casa dos setenta". (BORGES, 2001, p.20) 
Os cursos de formação iniciados por Padre Toninho, tornaram-se característicos da Pastoral Afro de todo o Brasil, porém, a Senhora A, da Paróquia Nossa Senhora Achiropita, informou que atualmente não há mais cursos na Paróquia. A mesma ressaltou, que os cursos formação não prosseguiram por falta de interesse dos Padres que passaram pela Paróquia, impedindo a perpetuação dos cursos, fazendo com que a PAB buscasse suas próprias estratégias de conscientização com a comunidade.

Entretanto, essa não é uma realidade dos núcleos do Rio de Janeiro, as líderes leigas da Pastoral Afro-brasileira relataram que no planejamento que acontece com os coordenadores de cada grupo da PAB do RJ, conforme discorre a Senhora Cecília.

"Eu não sei se eu já falei, mas, os nossos encontros são sempre no último sábado de cada mês e nós temos o encontro de formação, que ai normalmente são 2, 3 meses de diferença para o outro de espaço. Então, nós temos um trabalho, o trabalho é conjunto. A gente briga, mas, o trabalho é assim. As discussões são feitas nos seus grupos, que são levadas para essa comissão de coordenação".

As líderes leigas ressaltaram também, que o convite para participar desses cursos, não se restringe apenas aos paroquianos e membros da PAB, assim como, os convites que são feitos para ingressar na Pastoral. Não há restrição de membros, conforme destaca a Senhora Cecília "nós nunca dissemos que a pastoral é do negro. É aberto para quem veste a camisa, não importa se é branco dos olhos azuis, mas, vestiu a camisa, tá junto. A pastoral é para isso". $\mathrm{E}$ é dessa forma, que a mesma relata acontecer nos cursos de formação, enfatizando que todos são bem-vindos nos encontros, reuniões e principalmente nos cursos de formação, até mesmo pelo propósito de haver uma responsabilidade social, através desses cursos.

"A gente convida na paróquia e fala que as paróquias estão convidadas. Às vezes tem eventos como aconteceu em Santa Rosa de Lima (paróquia de Jardim América) convidaram os professores, porque era para falar da lei 10.639. E foram convidados. A gente amplia o público".

Portanto, entender e refletir sobre as considerações aqui expostas, referentes à importância da articulação das ações concretas da Pastoral Afrobrasileira, é de extrema contribuição, para que a PAB se torne mais visível. E principalmente para que os cristãos que não percebem o quanto entender a história da população negra, edifica sua missão evangelizadora, tendo em vista o propósito do leigo e da leiga, supracitado através dos documentos religiosos da Igreja Católica, exercendo o compromisso de se preocupar com o outro. 
E entender que embora a Igreja Católica tenha possibilitado o diálogo sobre a questão racial e ter permitido que existisse uma Pastoral que visse as demandas emanadas pela população negra, há também uma movimentação da própria instituição e de alguns cristãos que ainda tentam trazer invisibilidade para a Pastoral Afro-brasileira, impossibilitando que a PAB alcance seus objetivos.

"A Pastoral Afro-brasileira surge, portanto, como consequência de um longo processo de conscientização e militância de gerações de negros e negras, que assumem viver sua fé eclesial, tendo como referência a realidade da população afro-descendente no continente e no país". (Pastoral Afro Achiropita, 2013, p.07)

\subsection{3}

\section{A questão racial e a reflexão social da Pastoral Afro-brasileira através dos protagonistas da Pastoral Afro-brasileira}

Embora a Pastoral Afro-brasileira seja um instrumento de militância religiosa, a reflexão social é quem rege a maioria das articulações da Pastoral, visto que, o racismo é um problema social e não uma particularidade dentro da Igreja Católica. E desta forma, ela torna-se a base de atuação da PAB, direcionando as ações concretas e evidenciando a luta contra a discriminação racial, preconceito racial e racismo, em prol da igualdade racial.

Essas ações negativas que a população negra sofre é o tripé de atuação da Pastoral Afro-brasileira. E são pertinentes que sejam essas as demandas evidenciadas nas ações da Pastoral, pois, elas vêm sendo a preocupação dos negros cristãos desde que iniciaram sua articulação dentro da Igreja Católica, principalmente após a Conferência de Puebla em 1979, que falou abertamente sobre os negros.

Conforme relatado anteriormente, os líderes religiosos começaram sua militância em prol da questão racial, através dos movimentos sociais e pelas questões identificadas como atos negativos em relação à população negra. $E$ desta maneira, Padre Jurandyr ressalta o quão importante é saber distinguir cada um desses atos, que são conceitualmente diferentes, porém, são interligados, proporcionando uma maior propriedade das situações em que os negros estão expostos socialmente.

"Diferente do que pensamos, não é o preconceito que impulsiona o racismo, mas é através do racismo que surgem diferentes tipos de preconceitos. O racismo é fruto um mito criado sobre a cor de pele negra na qual o fenótipo (conjunto de características físicas de uma pessoa) são os escolhidos para terem criado um ódio e características negativas às pessoas com concentração alta de melanina". 
Para melhor contextualizar a questão do racismo, é preciso entender que ele além de ser fruto da escravidão, que denominavam como seres inferiores, incapazes e que dava de maneira ética o direito de explorá-los, desconsiderando totalmente a sua condição de ser humano. Mas, também da estrutural social em que estamos expostos, que acaba impedindo que as relações de dominação se perpetue. $O$ que fez com que despertasse nos beneficiários dessa prática, conceitos e atos preconceituosos em relação ao negro. A Igreja Católica também foi grande colaboradora dessa concepção, pois, dizia que Deus que determinava a inferioridade do negro.

"(...)O processo começou antes do primeiro africano chegar ao Brasil, teve sutis formas de sedimentação e arraigou-se a tal ponto na sociedade escravista que os preconceitos passaram à história e prevalecem ainda hoje, mais de cem anos depois da abolição". (CHIAVENATO, 1986, p.150)

O racismo corrobora para a perpetuação da estigmatização do negro, os expondo a situações discriminatórias, subalternidade, hierarquização, exigindo que a organização dessa população em prol da igualdade racial seja legítima. Esse aspecto contribui para fortalecer o grande mito da democracia racial, que está presente na sociedade desde o período da Abolição da escravatura, colaborando para o controle social e mantendo uma estrutura desigual em relação as "raças", com o propósito de não tornar o racismo e toda essa conjuntura um problema público. (Florestan Fernandes, 2005)

Essa afirmativa é enfatizada pelas considerações do Padre Jurandyr, ao dissertar sobre a questão racial e a sua representatividade na Pastoral Afrobrasileira. Considerando que as atribuições negativas que os negros recebiam no período em que foram escravizados se perpetuam até os tempos atuais, mesmo que a militância dos negros seja bastante efusiva atualmente.

"Á essas pessoas foram atribuídas diversas características negativas (gente amaldiçoada, suja, violenta, cabelo duro e ruim e etc), sustentadas pelas elites sociais em todas as épocas da história da humanidade, que se inseriram e perpetuaram no imaginário social, mantidas até os dias atuais".

Frei Tata também sinaliza, que a importância que a questão racial também para a articulação da Pastoral Afro-brasileira, se configura desde o surgimento da Pastoral. Principalmente por ela ter nascido no contexto das Conferências dos Bispos Latinos e Americanos, que consumaram a mudança centralizadora 
da Igreja Católica, para a questão social, assim como, no momento em que se almejavam políticas públicas para intervir nas expressões da questão social, aumentando sua responsabilidade com os tidos como excluídos socialmente, conforme sinaliza o Frei.

"Nasce no bojo do Movimento Negro Unificado, nasce no caldo político busca de políticas públicas para Negros e Negras representadas, por exemplo, pelo líder negro, Senador Abidias Nascimento. Nasce no contexto da luta do negro e da negra se ver na sociedade, no mercado de trabalho e nos meios de Comunicação Social. Zezé Mota, Rute de Souza, Grande Otelo viveram isto".

O Documento de Aparecida também traz reflexões que aludem à representatividade que a questão social tem para a Igreja Católica após as já referidas Conferências Episcopal Latino-Americana e Caribenha, por isso, à importância da Pastoral Afro-brasileira em trabalhar tal Documento. Padre Jurandyr, observa que as considerações expostas no Documento de Aparecida continuam sendo contemporâneas.

\begin{abstract}
"Temos trabalhado segundo o Documento de Aparecida, elaborado em maio de 2007, na V Conferência Episcopal Latino-americana e Caribenha, continua atual quando afirma: "A história dos afro-americanos tem sido atravessada por uma exclusão social, econômica, política e, sobretudo, racial, onde a identidade étnica é fator de subordinação social. Muitos são discriminados na inserção do trabalho, na qualidade e conteúdo da formação escolar, nas relações cotidianas e, além disso, existe um processo de ocultamento sistemático de seus valores, história, cultura e expressões religiosas. Permanece, em alguns casos, uma mentalidade e um certo olhar de menor respeito em relação aos afro-americanos. Desse modo, descolonizar as mentes, o conhecimento, recuperar a memória histórica, fortalecer os espaços e relacionamentos interculturais, são condições para a afirmação da plena cidadania destes povos".
\end{abstract}

Padre Jurandyr também atenta para a consideração do Papa João Paulo II a respeito do pedido de desculpa da Igreja Católica, para todo o tipo de omissão e discriminação. Visto que, que o papel da instituição foi de extrema importância para o processo de colonização e suas práticas discriminatórias, justificando e usufruindo da escravidão, como aponta o manual da Campanha da Fraternidade de 88.

"A Igreja, realidade ao mesmo tempo humana e divina, povo santo e pecador, vive, em cada tempo, a permanente tensão entre exigências do Evangelho e os condicionamentos históricos. Consciente de sua missão de viver e anunciar a utopia do reino e de ser portadora da memória da prática de Jesus e da comunidade apostólica, ela sabe que vive num mundo marcado pela desigualdade e pela opressão. A escravidão, o racismo e a discriminação, presentes na história da sociedade, estão também na história da Igreja". (Texto base da Campanha da Fraternidade de 1988, p.56) 
Ainda permeando a perspectiva do Papa João Paulo II e com os objetivos da Pastoral Afro-brasileira, Padre Jurandyr sinaliza o chamado que o Papa faz aos cristãos em virtude da postura conivente que a Igreja Católica teve durante o período da escravidão.

"A Igreja Católica - que, como lembrou o Bem-aventurado Papa João Paulo II, pede perdão a Deus, por algumas ações equivocadas ou algumas omissões em sua missão pastoral junto à população negra - "denuncia a prática da discriminação e do racismo em suas diferentes expressões, pois ofende no mais profundo a dignidade humana criada à imagem e semelhança de Deus". (cf. Documento de Aparecida, 533)".

E mesmo que atualmente a Igreja Católica, através da militância em prol da igualdade racial de leigos, leigas e líderes religiosos, dentro do espaço religioso que se estende para o âmbito social, o racismo ainda se faz presente na Igreja. O clero é majoritariamente branco e o negro que opta por viver o sacerdócio, ainda enfrenta muitas dificuldades, principalmente no seu primeiro contato que é o seminário. Frei Tata é um religioso negro, que relata com propriedade sobre essa situação e sinaliza que há também dificuldade de formação de líderes religiosos para atuar em prol das demandas da população negra "Na lgreja, há dificuldade da formação dos padres para assumirem a PAB, mesmo entre os Seminaristas Negros".

A questão racial está represente nas ações da Pastoral Afro-brasileira, de acordo com as leigas Dona Zica e Senhora Cecília, que sinalizam que a cultura afro é um dos exemplos dessa representatividade, sendo um dos instrumentos mais presente nas articulações da PAB. Dona Zica aborda que é importante que a cultura seja evidenciada não só dentro da Igreja Católica, mas também socialmente.

"Essa realidade do nosso povo negro, que nós enquanto pastoral, enquanto Igreja comprometida com o pobre, a Igreja fora dos muros, a Igreja com comprometimento como pastoral social é um desafio pra gente".

Embora a Pastoral Afro-brasileira seja um grupo religioso, conforme ressalta a Senhora Cecília, “(...) é importante isso, a gente falar enquanto Igreja, que nós somos da Igreja Católica. Então, nós somos um grupo, uma pastoral social da Igreja Católica”. E é importante destacar que um dos objetivos da PAB é o diálogo com a sociedade civil, com as organizações e com os movimentos sociais, o que fortalece ainda mais a responsabilidade social desenvolvida pela 
Pastoral, que foi contextualizada por Dona Zica, que caracterizou a importância que caminhar em conjunto.

\begin{abstract}
"Agora mesmo teve a marcha da mulher negra. E ai nós saímos daqui de Bangu. Saíram dois grupos separados. A gente se encontrou em um determinado local, pegamos o metrô, fomos para Copacabana, lá nos encontramos com o pessoal de Santa Rosa de Lima, com o pessoal de Lucas, nos encontramos com o pessoal de Santa Cruz e formamos todo um grupo. Separados nós somos pequenininho, mas, no conjunto somos grandes".
\end{abstract}

Essa consideração da Dona Zica colabora para o maior entendimento que a Pastoral Afro-brasileira se encontra preocupada com a luta anti-racista não só na instituição Igreja Católica, mas em toda a extensão social, se unindo a grupos e movimentos sociais que legitimam a luta a favor da igualdade racial. A igualdade que mesmo com o final do período da escravidão não foi alcançada pelos negros e que viabilizou, portanto, o surgimento da Lei $n^{0} \mathbf{1 2 . 2 8 8}$, de julho de 2010 (Estatuto da Igualdade Racial).

O Estatuto da Igualdade Racial foi apontado por Frei Tata, como um instrumento de grande relevância, que precisa ser reativado, a fim de tornar a luta dos movimentos sociais ainda mais consistente. O referido Estatuto tem o propósito não só de combater a discriminação racial e o racismo, como promover a efetiva igualdade racial, influenciada pela noção da Constituição Federal de 1988, que visa a garantia de direitos de todos os cidadãos.

"Mais recentemente, a mudança - ou - de perspectiva ganhou relevo institucional com a implantação de agências dentro do Estado especialmente destinadas à promoção da igualdade racial. É assim que surgem entes como a Secretaria de Políticas de Promoção da Igualdade Racial da Presidência da república (Seppir) e o Conselho Nacional de Promoção da Igualdade Racial (CNPIR) e iniciativas como a Política Nacional de Promoção da Igualdade Racial (PNPIR) e o Plano Nacional de Promoção da Igualdade Racial (Planapir)". (PAIM, 2010, p.11)

E visto que o Brasil vive o racismo institucional, torna-se ainda mais pertinente que haja um Estatuto que vive a igualdade racial, visando garantir a igualdade de oportunidades da população negra. Advertindo também sobre a importância de se combater todo e qualquer tipo de intolerância étnica, assegurando, portanto, os direitos étnicos coletivos e individuais. Permeando essa temática, Padre Jurandyr faz uma ressalva pertinente que ilustra de maneira clara a preocupação do Estatuto da Igualdade Racial.

"O racismo institucional ou sistêmico opera de forma a induzir, manter e condicionar a organização e a ação do Estado, suas instituições e políticas 
públicas - atuando também nas instituições privadas, produzindo e reproduzindo a hierarquia racial. Grande parte da população assume esta bandeira sem perceber que a solução não passa pela criminalização da adolescência, mas pela educação das novas gerações. Um dos grandes problemas da humanidade é a delinquência. O Brasil é o terceiro país do mundo em número de prisioneiros"

Portanto, torna-se de extrema relevância que as ações concretas da Pastoral Afro-brasileira, sejam pautadas nas expressões da questão social, que assolam todas as classes sociais, porém, enfaticamente os tidos como excluídos que compõe a camada mais vulnerável da sociedade, como, por exemplo, os mais pobres, negros e marginalizados. 


\section{Conclusão}

Por todos as considerações mencionadas nessa pesquisa, em relação a gênese da Pastoral Afro-brasileira e sua articulação em prol da igualdade racial, em todos os âmbitos sociais, como no seio da Igreja Católica, com a população local e com os Movimentos Sociais, constato que é de suma importância que existam mais estudos que debrucem seu olhar para a PAB. Pois, sua reflexão, remete as questões mais latentes da sociedade, como o presente racismo, que faz parte da estrutura social e causa diretamente danos na vida dos negros e que alimenta ainda mais a exclusão dessa população.

A Pastoral Afro-brasileira é um campo rico para ser explorado academicamente, tendo em vista que um dos seus principais papéis é o de agente social, por agir no processo de construção da identidade racial. $E$ conforme sinalizado nessa pesquisa, a PAB traz profunda relevância na intervenção contra a desigualdade racial, pois, realiza ações que tangem a luta contra o racismo, a discriminação racial, preconceito e a desigualdade racial, exaltando a identidade negra. Intervindo através de ações concretas nessas questões expostas pelo mundo contemporâneo, de acordo com apontamentos de Octavio lanni (2003).

A pesquisa não só evidenciou a trajetória da criação da Pastoral Afrobrasileira, mas como também, a importância das suas ações concretas, que enaltecem a identidade e a cultura afro, que são articuladas e promovidas pelos principais protagonistas leigos e religiosos da $\mathrm{PAB}$. $O$ que colabora para evidenciar ainda mais a importância da Pastoral na luta contra o racismo, que faz parte da estrutura social do país, que é discriminatória em sua essência.

Considero também, que esse estudo se torna grandioso, por alertar que embora a instituição Igreja Católica, tenha consciência da sua conivência e participação durante o período escravocrata, afirmativa essa em concordância com as considerações do Manual da Campanha da Fraternidade de 1988, o racismo ainda é uma prática encontrada na instituição. E visto que, o Serviço Social é uma profissão que buscar intervir nas diversas expressões da questão social, que gera a grande desigualdade social, torna-se pertinente, o debate da profissão em relação a desigualdade racial.

O profissão de Serviço Social, deve prezar pela igualdade de todos os indivíduo, reforçando o compromisso que o assistente social deve ter em seu 
exercício profissional, salientando a construção de uma ordem igualitária socialmente. Corroborando ainda mais a importância de estudar a Pastoral Afrobrasileira, que mesmo que tenha surgido como resultado da militância dos negros cristãos, com o objetivo de dialogar sobre a questão racial e até mesmo amenizar o racismo na instituição, ainda se encontra ações excludentes em relação a cultura afro. Ocasionando atos racistas dentro da Igreja, por essa prática ser tão enraizada e compor a estrutura social.

Porém, não há como sucumbir que tiveram pontos positivos provenientes da inserção da Pastoral Afro-brasileira dentro da Igreja Católica, que contribuíram para que o negro se sentisse mais pertencente a instituição. Constata-se essa consideração através dos relatos das lideranças leigas, que sinalizaram que em suas paróquias atualmente, há mais participação dos negros nas atividades paroquiais, como leituras nas celebrações não inculturadas, presença nas coroações de Nossa Senhora, comando atividades religiosas, coordenando grupos pastorais, dentre outras iniciativas dentro da Paróquia.

Além do mais, um dos objetivos da Pastoral Afro-brasileira que é tornar visível a cultura afro, que tanto influência nos costumes do país, mas, que não é evidenciada, através das celebrações inculturadas, a Igreja passa a tornar visível a identidade do negro dentro da instituição, sinalizando o quão grande é sua influência nos hábitos sociais do país. Mas, essa visibilidade não é o suficiente para que todos os cristãos vejam a inserção da PAB como algo pertinente para os princípios da Igreja Católica, principalmente por ainda endemonizar tudo o que remete a ancestralidade negra, enfaticamente as religiões de Matriz africana.

Considero também, que através dos estudos realizados, se percebe que tenha tido avanço em relação a participação do negro e o entendimento da sua história, mas, que ainda não foi suficiente para a total supressão do racismo dentro da Igreja Católica. E que há muito para avançar, mesmo tendo em vista, a grande importância da reflexão social que a Pastoral Afro-brasileira desenvolve, ganhando um papel de grande destaque, em relação a responsabilidade social.

Portanto, o estudo sobre a Pastoral Afro-brasileira deve prosseguir, por trazer visibilidade as demandas da população negra, assim como, pelo importante papel social que a PAB desenvolve junto aos Movimentos Sociais, demonstrando que a militância negra deve estar presente em todos os âmbitos em que os negros estiverem presentes. E mesmo que a história revele o passado discriminatório da Igreja Católica, há negros que se sentem 
religiosamente contemplados nessa instituição e que por isso, almejam sentir-se parte dela.

A pesquisa além de relatar a gênese da Pastoral Afro-brasileira e sua responsabilidade social em prol da igualdade racial, visa também, externar a importância de pesquisar mais um agente social, que colabora para que as práticas que discriminam e excluem os negros socialmente sejam amenizadas na contemporaneidade. Abrindo um leque para que outros pesquisadores possam dissertar sobre as demandas que não foram sinalizadas nessa pesquisa, mas, que eu enquanto pesquisadora pude observar, como por exemplo, protagonismo da mulher negra a frente dos Movimentos Sociais, a invisibilidade e demonização das religiões de Matriz africana e a falta de diálogo sobre a questão racial dentro da Igreja Católica, mesmo com a existência da Pastoral Afro-brasileira.

Por tudo aqui exposto, considero que todas as ações concretas expostas na pesquisa, como o diálogo inter-religioso, a caminhada ao lado dos Movimentos Sociais que visam intervir nas demandas da população tida como excluídas e o debate sobre o tripé de atuação da PAB. Que está focado na discriminação racial, preconceito racial e racismo, são de indispensável importância para o a academia, no sentindo de desbravar as práticas discriminatórias e principalmente para a luta da população negra.

Ressaltando também, a importância de se desenvolver mais estudos nos departamentos de Serviço Social, que enfatizem a grande relevância de estudar sobre um agente social tão grandioso, que articula ações concretas em prol da igualdade racial, como a Pastoral Afro-brasileira. 


\section{Referências bibliográficas}

ANDREATTA, Alcides. Missão do Cristão leigo na Igreja e no mundo. Uma leitura Teológico-Pastoral à luz dos documentos das Conferências do Episcopado da América Latina e Caribe. FAJE Faculdade Jesuíta de Filosofia e Teologia. Belo Horizonte: 2009.

AGUIAR, Victor Rafael Laurenciano, and Claudio Melquiades Medeiros. Entrevistas na pesquisa social: o relato de um grupo de foco nas licenciaturas. Congr. Nac. Educação, EDUCERE 9 (2009): 10-710.

ARAUJO, Jurandyr Azevedo. II Seminário de Teologia da Pastoral Afrobrasileira: Um olhar sobre a caminhada da Pastoral Afro-brasileira da CNBB (PAB/CNBB) 2010 (Texto gentilmente cedido pelo autor).

Jurandyr Azevedo. Compromisso da Pastoral Afro-brasileira. Decenio Internacional para os Afrodescendentes (2015-2024). 2015 (Texto gentilmente cedido pelo autor).

, Jurandyr Azevedo. Uma nova pastoral Afro-brasileira precisa de coragem 2016 (Texto gentilmente cedido pelo autor).

AZEVEDO, Marcello de Carvalho. Viver a fé cristã nas diferentes culturas. Edicoes Loyola, 2001.

BETTO, Frei. O que é Comunidade Eclesial de Base (São Paulo: Brasiliense, 1981); Bruneau ThePoliticai Transformation, Ch. 9 on ChurchState Conflict; Marcio Moreira Alves. A Igreja e a Política no Brazil.

BORGES, Rosangela. Axé, madona Achiropita!: presença da cultura afro-brasileira nas celebrações da Igreja de Nossa Senhora Achiropita, em São Paulo. Edições Pulsar, 2001.

CALÓGERAS, P. de M. Formação Histórica do Brasil. São Paulo: 1927.

CELAM - Conselho Epsicopal Latino-Americano. Linhas Pastorais AfroAmericano. Bogotá-Colômbia: 2003.

CHIAVENATO, Julio José. O negro no Brasil: da senzala à Guerra do Paraguai. Brasiliense, 1986.

CICONELLO, Alexandre. 0 desafio de eliminar o racismo no Brasil: a nova institucionalidade no combate à desigualdade racial. Oxfam International, 2008. Disponível em: WWW.fp2p.org Acesso: 16 de maio de 2017. 
CONEGERO, Daniel. Como Evangelizar e o Que é Evangelismo? Disponível em: <https://estiloadoracao.com/como-evangelizar/> Acessado em: 05 de novembro de 2017.

CONGRESSO NACIONAL DAS ENTIDADES NEGRAS CATÓLICAS, 7 , 2011. Londrina PR. A Pastoral Afro-brasileira e os desafios no século XXI. Brasília: Confederação Nacional dos Bispos do Brasil, 2012.

CONGRESSO NACIONAL DAS ENTIDADES NEGRAS CATÓLICAS, 8, 2014. Duque de Caxias. Profetismo. Construindo uma sociedade justa e solidária. Brasília: Confederação Nacional dos Bispos do Brasil, 2015.

CONGRESSO NACIONAL DAS ENTIDADES NEGRAS CATÓLICAS, 7, 2017. Maringá PR. Articular a palavra de Deus e os documentos da Igreja para apontar caminhos. Brasília: Confederação Nacional dos Bispos do Brasil, 2018.

COSTA, Eduardo M.I. da. A Igreja no Brasil Colônia, 2010. Disponível em: <http://seguindopassoshistoria.blogspot.com.br/2010/02/igreja-nobrasil-colonia.html> Acesso em 05 de Setembro 2015.

CNBB: campanha pede oportunidade para adolescente infrator

Disponível em: <https://noticias.cancaonova.com/brasil/cnbb-campanhapede-oportunidade-para-adolescente-infrator/> Acessado em: 20/12/2017.

CNBB. O que é pastoral Social? Cartilhas de pastoral social, ㄲo 1. São Paulo: Edição Loyola, 2001.

CNBB. Pastoral Afro-brasileira. Estudos da CNBB no․ 85. São Paulo: Paulus, 2002.

CNBB. Pastoral Afro-Brasileira: Princípios de Orientação. Brasília: Edições CNBB, 2008.

CNBB. Brasil - $\mathbf{5 0 0}$ anos de diálogo e Esperança. São Paulo: Paulinas, 2000.

DA SILVA, Paulo Vinícius Baptista. Educação das relações étnico-raciais na terra das araucárias. Diversidade etnico-racial e educação superior Brasileira: experiências de intervenção (2008).

FERNANDES, Florestan. A integração do negro na sociedade de classes: no limiar de uma nova era. Globo Livros, 2008.

GIL, Antonio Carlos. Métodos e técnicas de pesquisa social. 6. ed. Ediitora Atlas SA, 2008. 
GODOY, Cida. Uma experiência de Deus na comunidade negra Afro Achiropita Fé, Resistência e Identidade Negra. 2013 (Texto gentilmente cedido pela Pastoral Afro Achiropita).

GOMES, Nilma Lino. Alguns termos e conceitos presentes no debate sobre relações raciais no Brasil. Brasil. MEC/SECAD. Educação antiracista: caminhos abertos pela Lei Federal 10.639/03 (2011).

, Nilma Lino. Educação e identidade negra. Aletria: Revista de Estudos de Literatura, v. 9, p. 38-47, 2002.

Nilma Lino. Educação, identidade negra e formação de professores/as: um olhar sobre 0 corpo negro e 0 cabelo crespo. Educação e pesquisa, v. 29, n. 1, p. 167-182, 2003.

Nilma Lino. Relações étnico-raciais, educação e descolonização dos currículos. Currículo sem fronteiras 12.1 (2012): 98-109.

GUIMARÃES, Antonio Sérgio Alfredo. Classes, raças e democracia. Editora 34, 2002.

HASENBALG, Carlos Alfredo. Discriminação e desigualdades raciais no Brasil. Rio de Janeiro: Graal, 1979.

IANNI, Octavio. Dialética das relações raciais. Revista Estudos avançados, no - 18, 2004.

IR, Márcio (Alagoinhas), EDMILSON, M.S. Oliveira (Cícero Dantas), ALBERTO, S. (Remanso), DIÁC. Genival J. Araújo (Rui Barbosa), AIDIL, Vaz, AMOURA, C. História do negro brasileiro. São Paulo: Ática, 1989.

LARA, Ricardo; SILVA, Mauri Antônio da. A ditadura civil-militar de 1964: os impactos de longa duração nos direitos trabalhistas e sociais no Brasil. Revista Serviço Social e Sociedade, n. 122, p. 275-293, 2015.

\section{LATINO- AMERICANO, CONSELHO EPISCOPAL. Conclusões da}

Conferência de Puebla: Evangelização no presente e no futuro da América Latina. São Paulo: Paulinas, 1982.

MINAYO, Maria Cecilia de Souza et al. Pesquisa Social: Teoria. Método e criatividade, v. 5, 1994. MIRANDA, Ana Paula Rocha, and Patrícia Barreto Cavalcanti. O Serviço Social e sua ética profissional. Revista Agora (2005).

MUNANGA, Kabengele. Algumas considerações sobre "raça", ação afirmativa e identidade negra no Brasil: fundamentos antropológicos. Revista USP, n. 68, p. 46-57, 2006. 
cidadania. Acesso em, v. 7, 2015.

NETTO, José Paulo. Desigualdade, pobreza e Serviço Social. Revista Em pauta (Revista da faculdade de Serviço Social da UERJ), no - 19, 2007.

OLIVEIRA, Ralfy Mendes. 0 que é evangelização na teologia católica. Disponível em: <http://www.ultimato.com.br/revista/artigos/286/o-que-eevangelizacao-na-teologia-catolica> Acessado em: 29 de outubro de 2017

OLIVEIRA, Rosenilton Silva de. Negros militantes católicos ou católicos militantes negros? - Percurso da Pastoral Afro-brasileira. Salvador, 2011.

Rosenilton Silva de. Orixás: a manifestação cultural de Deusuma análise das liturgias católicas inculturadas. 2011. Tese de Doutorado. Universidade de São Paulo.

PAIXÃO, Joselito Alves da P. Pastoral Afro-brasileira - Sob os aspectos preliminares como iniciativa para arquidiocese do Rio de Janeiro. 2013 (Texto gentilmente cedido pelo autor).

PAIM, Paulo. Estatuto da igualdade racial. 2003.

PASSOS, João Décio. Concílio Vaticano II: reflexões sobre um carisma em curso. Pia Sociedade de São Paulo - Editora Paulus, 2014.

PASTORINI, Alejandra. A categoria "questão social" em debate. São Paulo Cortez, 2004.

PEDRO, Aquilino de. Dicionário de termos religiosos e afins. Aparecida: Santuário, 1993. Revista Brasileira de Diálogo Ecumênico e Interreligioso Ano 02, no02, janeiro a julho de 2014 - Caminhos de diálogo Pluralismo Religioso: Horizontes Abertos.

SALVADOR, Andreia Clapp. A gênese da política de ação afirmativa da PUC-Rio. Uma parceria entre Universidade e Movimento Social. Rio de Janeiro, 2009.

SANTOS, D. Raimundo. Ano da Vida consagrada: O que você tem feito por uma Igreja Etnicamente Comprometida. 2014 (Texto gentilmente cedido pelo autor).

SANTOS, Joseane Soares. Questão Social: particulares no Brasil. São Paulo, Cortez Editora, 2012.

SILVA, Antonio Aparecido, Marcos Rodrigues SILVA, and Petronilha Beatriz Gonçalves SILVA. Agentes de Pastoral Negros 10 anos 1983- 
1993: conscientização, organização, fé e luta. São Paulo: AtabaqueASETT (Associação de Teólogos do Terceiro Mundo) (1993).

SILVA, Jorge da. 120 Anos de Abolição: 1888-2008. Rio de Janeiro: Hama, 2008.

STUART, Hall, and Woodward Hathryn. Quem precisa da identidade. Identidade e diferença. Rio de Janeiro: Editora Vozes (2007).

ZIN, Rafael Balseiro. Literatura e afrodescendência no Brasil dos oitocentos: uma proposta de investigação a partir da análise interna do romance Úrsula (1859) de Maria Firmina dos Reis. São Paulo, 2013. 


\section{Apêndice}

6.1

\section{Questionário para os membros da Pastoral Afro-brasileira}

1- Quando a nasce a PAB na sua paróquia?

2-Na sua visão qual a importância da PAB? E quais são as maiores dificuldades e facilidades enfrentadas pela sua PAB?

3-Quais são as atividades promovidas pela PAB de que você participa?

4-Ocorre curso de capacitação promovido pela PAB de que você participa? Se sim, geralmente quais são os temas abordados e quem são os participantes desses cursos, além dos membros da PAB?

5-A cultura afro-brasileira sempre é evidenciada nos encontros e missas de que

a PAB participa e promove?

6-Para você o que é questão racial e de que forma ela está representada na $\mathrm{PAB}$ ?

7-Você sabe qual a origem da PAB no Brasil? Se sim, fale um pouco sobre isso. 8-Você gostaria de falar mais alguma coisa sobre a PAB? 


\section{2}

Questionário para os líderes religiosos participantes da Pastoral Afro-brasileira

1-Há quanto tempo está inserido na PAB?

2-Durante esse tempo quais foram as conquistas mais importantes da PAB no âmbito da lgreja e social?

3-Na sua visão, qual a importância da PAB? E quais são as maiores dificuldades e facilidades enfrentadas desde o início da sua atuação na PAB?

4-Para você o que é questão racial e em sua opinião ela está representada na PAB?

5-Você sabe qual a origem da PAB no Brasil? Se sim, fale um pouco sobre isso.

6-Você gostaria de falar mais alguma coisa sobre a PAB? 